\title{
ANÁLISE COMPARATIVA DA EFETIVIDADE DA FIBRA DE VOLUMOSOS E SUBPRODUTOS
}

\author{
MILTON LUIZ MOREIRA LIMA
}

\author{
Tese apresentada à Escola Superior de \\ Agricultura "Luiz de Queiroz", Universidade de \\ São Paulo, para obtenção do título de Doutor \\ em Agronomia, Área de Concentração: \\ Ciência Animal e Pastagens
}

\author{
PIRACICABA \\ Estado de São Paulo - Brasil \\ Janeiro - 2003
}




\title{
ANÁLISE COMPARATIVA DA EFETIVIDADE DA FIBRA DE VOLUMOSOS E SUBPRODUTOS
}

\author{
MILTON LUIZ MOREIRA LIMA \\ Zootecnista
}

Orientador: Prof. Dr. Wilson Roberto Soares Mattos

\author{
Tese apresentada à Escola Superior de \\ Agricultura "Luiz de Queiroz", Universidade de \\ São Paulo, para obtenção do título de Doutor \\ em Agronomia, Área de Concentração: \\ Ciência Animal e Pastagens
}

\author{
PIRACICABA \\ Estado de São Paulo - Brasil \\ Janeiro - 2003
}




\section{Dados Internacionais de Catalogação na Publicação (CIP)}

DIVISÃO DE BIBLIOTECA E DOCUMENTAÇÃO - ESALQ/USP

Lima, Milton Luiz Moreira Análise comparativa da efetividade da fibra de volumosose subprodutos/ Milton Luiz Moreira Lima. - - Piracicaba, 2002.

$121 \mathrm{p}$.

Tese (doutora do) - Escola Superior de Agricultura Luiz de Queiroz, 2003. Bibliografia.

1. Alimentos vegeta is para a nima is 2. Alimentos volumosos 3. Dieta a nimal 4. Fibra s vegeta is 5 . La c ta ção a nimal 6 . Subprodutos para a nima is I. Título

CDD 636.084 
A memória de meu pai, Milton, e a minha mãe, Helenice,

\section{DEDICO}




\section{AGRADECIMENTOS}

À Coordenação de Aperfeiçoamento de Pessoal de Nível Superior (CAPES), pela concessão das bolsas de estudos no Brasil e no exterior.

À Fundação de Amparo à Pesquisa do Estado de São Paulo (FAPESP), pelo financiamento do projeto no Brasil.

Ao Departamento de Produção Animal, da Escola de Veterinária, da Universidade Federal de Goiás, pela concessão do afastamento para cursar pós-graduação.

Ao Prof. Dr. Wilson Roberto Soares Mattos pelo apoio, orientação e amizade.

Ao Prof. Dr. Luiz Gustavo Nussio pelos ensinamentos, confiança e amizade.

Ao Prof. Dr. Sila Carneiro da Silva pelos ensinamentos e exemplo de profissionalismo.

A Profa. Dra. Ivanete Susin pelo apoio durante meus preparativos para viagem ao exterior.

Aos colegas de curso Marco Antônio Alvares Balsalobre, Ricardo Pereira Manzano e Flávio Geraldo Ferreira Castro sem os quais seria impossível conduzir minha pesquisa no Brasil.

Ao funcionário do Laboratório de Bromatologia Animal do Departamento de Produção Animal Carlos César Alves, pela amizade, ensinamentos e paciência durante as análises laboratóriais.

Aos demais professores do Departamento de Produção Animal pela cordialidade e amizade. 
Ao Prof. Dr. Virgílio F. Nascimento Filho, do Laboratório de Instrumentação Nuclear/CENA, pelas análises de Cobalto, Cromo e Itérbio nas amostras de fezes.

Ao meu orientador no exterior, Prof. Dr. Jeffrey L. Firkins, do Department of Animal Sciences da The Ohio State University, pelos ensinamentos, pelo financiamento da pesquisa no exterior, apoio e amizade.

Aos colegas Claudio Ribeiro, Susan Noftsger, John Sylvester, Sanjay Karnati, Jenn Beckman, Sara Larsen, Sarah Adams e Carine Revenau, de Columbus, OH, EUA, pela amizade e contribuição decisiva para o desenvolvimento da pesquisa no exterior. 


\section{SUMÁRIO}

Página

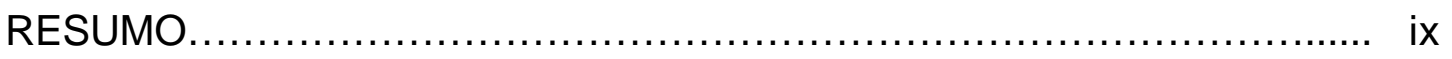

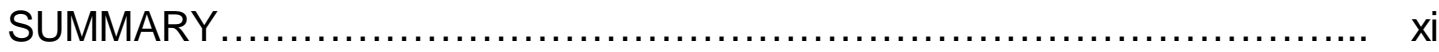

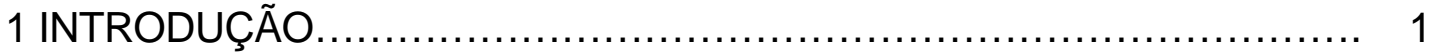

2 REVISÃO DE LITERATURA........................................... 6

2.1 Caracterização da fração fibra............................................ 6

2.2 Efetividade baseada na atividade de mastigação......................... 8

2.3 Quantificação da efetividade............................................. 10

2.4 Uso da porcentagem de gordura no leite para quantificar efetividade... 13

2.5 Atividade de mastigação versus porcentagem de gordura no leite como critérios de resposta............................................... 14

2.6 Efetividade e o meio ambiente ruminal................................... 15

2.7 Forragens como fonte de fibra efetiva................................... 18

2.7.1 Tamanho de partículas e efetividade da fibra........................... 18

2.7.2 Composição da FDN e efetividade da fibra............................ 24

2.8 Silagem de milho versus cana-de-açúcar - Consumo e produção de

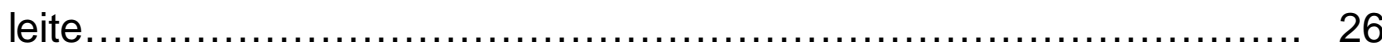

2.9 Subprodutos como fontes de fibra não forragem (FFNF) ................ 29

2.10 Efeitos de FFNF sobre a digestibilidade ............................... 32

2.11 Efetividade de FFNF................................................. 35

2.12 Resposta na produção de leite quando FFNF substituem forragens... 37

2.13 Efeitos de longo prazo do uso de FFNF.............................. 37

3 ANÁLISE COMPARATIVA DA EFETIVIDADE DA FIBRA DE

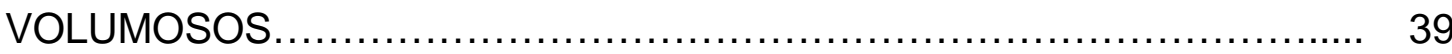




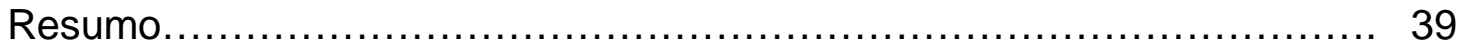

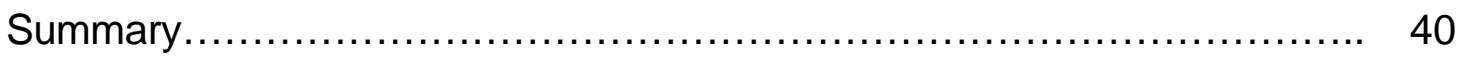

3.1 INTRODUÇÃO ............................................................ 40

3.2 MATERIAL E MÉTODOS........................................... 44

3.2.1 Animais, tratamentos e delineamento experimental.................. 44

3.2.2 Amostragens e análises laboratoriais................................ 46

3.2.3 Análise estatística...................................................... 52

3.3 RESULTADOS E DISCUSSÃO....................................................... 53

3.3.1 Composição química e tamanhos de partículas das forragens............ 53

3.3.2 Composição química das dietas........................................................ 55

3.3.3 Consumo e digestibilidade............................................................. 57

3.3.4 Produção e composição do leite...................................................... 60

3.3.5 Ácidos graxos voláteis e pH ruminal..................................................... 61

3.3.6 Taxa de passagem......................................................................

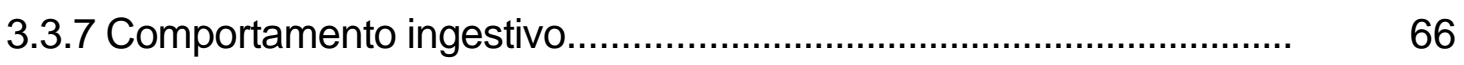

3.3.8 Consitência do "mat" ruminal.................................................................... 69

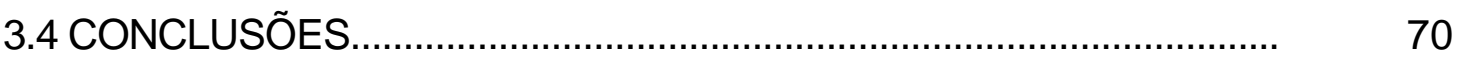

4 ANÁLISE COMPARATIVA DA EFETIVIDADE DA FIBRA DE SUBPRODUTOS..................................................................................

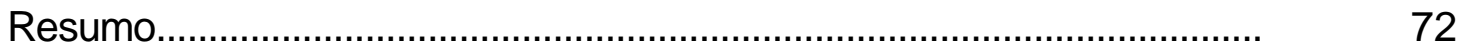

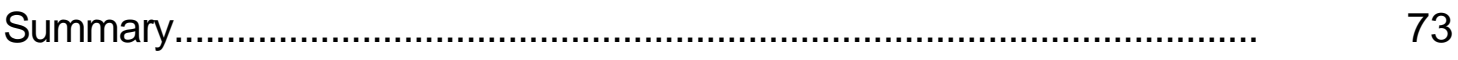

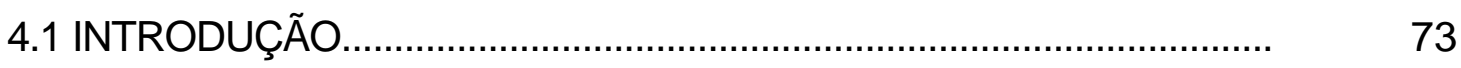

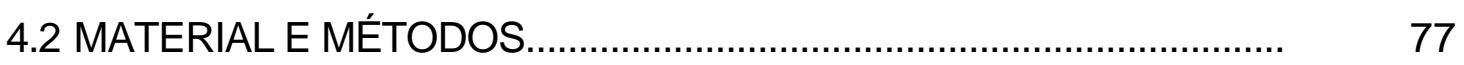

4.2.1 Animais, tratamentos e delineamento experimental............................ 77

4.2.2 Amostragens e análises laboratoriais................................................... 79

4.2.3 Análise estatística....................................................................... 83

4.3 RESULTADOS E DISCUSSÃO.............................................................. 84

4.3.1 Composição química das dietas e forragens...................................... 84

4.3.2 Consumo alimentar........................................................................ 86

4.3.3. Produção e composição do leite ......................................................... 88 


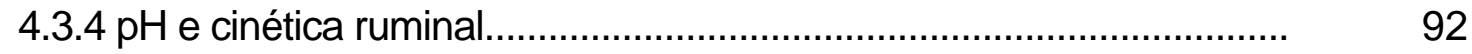

4.3.5 Comportamento ingestivo................................................................. 96

4.3.6 Consistência do "mat" ruminal................................................................. 98

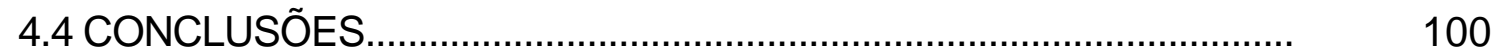

5 CONCLUSÕES GERAIS .................................................................. 101

REFERÊNCIAS BIBLIOGRÁFICAS....................................................... 102 


\title{
ANÁLISE COMPARATIVA DA EFETIVIDADE DA FIBRA DE VOLUMOSOS E SUBPRODUTOS
}

\author{
Autor: MILTON LUIZ MOREIRA LIMA \\ Orientador: Prof. Dr. WILSON ROBERTO SOARES MATTOS
}

\section{RESUMO}

Com o objetivo de avaliar a efetividade da fibra de volumosos e subprodutos, foram conduzidos dois experimentos utilizando vacas em lactação. No experimento I, cinco vacas holandesas com cânulas no rúmen e duodeno foram utilizadas em um delineamento quadrado latino $5 \times 5$ para avaliar a efetividade da fibra da cana-de-açúcar "in natura" (CAN) ou tratada com $\mathrm{NaOH}$ (CAS). Duas dietas, uma com baixa e outra alta porcentagem de FDN oriunda de forragem (14 e $22 \%$ de FDN na MS a partir de silagem de milho, respectivamente), foram comparadas com dietas balanceadas para conter $14 \%$ de FDN de silagem de milho e $8 \%$ de FDN proveniente CAN, CAS ou feno de alfafa (FA), em porcentagem da MS. O consumo de matéria seca, produção e composição do leite não foram afetados pela concentração ou fonte de FDN das dietas. $\mathrm{O}$ pH ruminal, proporções molares de ácidos graxos voláteis e relação acetato:propionato foram afetados pela concentração e fonte de FDN das dietas. O tempo de mastigação (min./d e min./kg de MS) foi menor na dieta com $14 \%$ de FDN, porém não diferiu para as dietas com $22 \%$ de FDN de forragem. Considerando os resultados para teor de gordura no leite $e$ comportamento ingestivo foi possível concluir que as forragens avaliadas 
apresentaram efetividades da fibra equivalentes. No experimento II, seis vacas holandesas com cânulas no rúmen foram utilizadas em um delineamento quadrado latino $6 \times 6$ para avaliar a importância da presença de linter ou tamanho de partículas da semente de algodão na sustentação da função ruminal e atividade de mastigação em dietas com baixa porcentagem de forragem. Quatro formas de processamento das sementes foram utilizadas e as vacas receberam seis dietas completas que constituíram os seguintes tratamentos: Dieta baixa forragem (DBF) - dieta com $16 \%$ de FDN de forragem (FDNF); Dieta alta forragem (DAF) - dieta com 21\% de FDNF; linter - dieta com $16 \%$ de FDNF + 5\% de FDN de sementes de algodão; amido - dieta com 16\% de FDNF + $5 \%$ de FDN de sementes tratadas com amido gelatinizado de milho; sem linter - dieta com 16\% de FDNF + 5\% de FDN de sementes sem linter; peletizada - dieta com $16 \%$ de FDNF $+5 \%$ de FDN de sementes peletizadas. $O$ consumo de matéria seca não foi afetado pela forma de processamento das sementes, porém, foi observado aumento no consumo de MS, quando as dietas com sementes foram comparadas à dieta com $21 \%$ de FDN. A produção de leite foi maior para dieta com $16 \%$ de FDNF, porém, não houve efeito de tratamento sobre a porcentagem de gordura no leite. Os tempos de ruminação e mastigação (min./kg de MS e min./kg de FDN) foram menores para as dietas com semente de algodão, quando comparadas à dieta com $21 \%$ de FDNF. A efetividade da fibra de semente de algodão foi ligeiramente inferior a de forragens, porém, não foi possível definir se linter ou tamanho de partículas foram os fatores determinantes da efetividade. 


\section{COMPARATIVE EVALUATION OF FIBER EFFECTIVENESS OF FORAGE AND BYPRODUCTS}

Author: Milton Luiz Moreira Lima

Adviser: Prof. Dr. Wilson Roberto Soares Mattos

\section{SUMMARY}

Two experiments were conducted to evaluate fiber effectiveness of forages and byproducts. In experiment I, five ruminally cannulated Holstein cows were used in a $5 \times 5$ Latin square design to evaluate fiber effectiveness of sugarcane (SC) and sodium hydroxide treated sugarcane (SHSC). Low and high forage diets (14 and $22 \%$ of dietary DM from corn silage NDF, respectively) were compared with diets formulated to contain 14\% of DM from corn silage NDF plus $8 \%$ of DM from SC NDF or SHSC NDF or alfalfa hay NDF (AF). Dry matter intake, milk yield and composition did not differ across diets. Ruminal $\mathrm{pH}$, VFA and acetate:propionate were affected by level and source of NDF. Chewing time (min./d and min./kg of DMI) was lower for low forage diet but, did not differ between high forage, SC, SHSC and AF diets. The results suggest that SC, SHSC and AF were as effective as corn silage for maintaining milk fat test and stimulating chewing. In experiment II, six ruminally cannulated Holstein cows were used in a $6 \times 6$ Latin square design to evaluate the role of specific fractions of whole cottonseeds in sustaining rumen function as mesuared by mat consistency, particulate passage rate, and chewing response. Whole 
cottonseeds (WCS), starch-coated WCS (EAS), mechanically delinted cottonseed (DEL) and pelleted WCS (PEL) were used and the six dietary treatments were: low forage diet (LFD) $-16 \%$ of DM from forage NDF (FNDF); high forage diet (HFD) $-21 \%$ of DM from FNDF; WCS - 16\% FNDF plus $5 \%$ of DM from WCS NDF; EAS - 16\% FNDF plus 5\% of DM from EAS cottonseed; DEL - $16 \%$ FNDF plus $5 \%$ of DM from DEL cottonseed, and PEL - 16\% FNDF plus $5 \%$ of DM from DEL cottonseed, and PEL - 16\% FDNF plus 5\% of DM from pelleted WCS. Dry matter intake did not differ across cottonseed treatments but it was higher than HFD treatment. Milk yield was higher for LFD but, milk fat percentage was not affected treatments. Ruminating and chewing activity were lower for cottonseed diets than HFD. Fiber effectiveness was lower for cottonseed and it was not possible to isolate the role of linter or particle size in sustaining rumen. 


\section{INTRODUÇÃO}

Fibra é um componente essencial da dieta de vacas em lactação necessário para alcançar consumo máximo de matéria seca (MS) e energia, para manter normal a fermentação no rúmen e porcentagem de gordura no leite, e ajudar na prevenção de desordens metabólicas do pós-parto. Por outro lado, a fibra é composta por carboidratos de digestão lenta e, quando incluída em quantidades excessivas na dieta, pode limitar o consumo de matéria seca e energia, afetando diretamente a produção de leite e a reprodução de rebanho leteiros.

A fibra pode ser avaliada através de métodos químicos e físicos e o correto balanceamento de dieta depende, cada vez mais, da combinação destes métodos. Os métodos químicos para determinação de fibra bruta (FB), fibra detergente neutro (FDN) e fibra detergente ácido (FDA) são os mais utilizados para avaliar a concentração de fibra dos alimentos. Em função de suas inconsistências, o método da FB vem sendo abandonado como forma de avaliação da fração fibrosa, tanto para fins de determinação da concentração de fibra como para o balanceamento de dietas. Assim, os métodos de FDN e FDA são utilizados atualmente para expressar a concentração de fibra e para o balanceamento de rações de bovinos leiteiros.

A determinação da distribuição de partículas por tamanho vem sendo proposta como método físico auxiliar de avaliação da fibra de alimentos, principalmente forragens, destinados à alimentação de bovinos leiteiros. Recentemente, um método rápido e prático de determinação da distribuição de partículas por tamanho foi desenvolvido por pesquisadores da universidade da 
Pennsylvania - USA (Heinrichs e Lammers, 1997). Este método utiliza um conjunto de peneiras (Penn State Forage Particle Separator) e tem por objetivo avaliar a distribuição de partículas por tamanhos de forragens e rações completas, combinando assim, medidas químicas (porcentagem de FDN) e físicas (tamanho de partículas) no balanceamento de dietas para vacas em lactação.

Apesar de não adotar medidas físicas para estabelecer ou ajustar exigências de fibra, o NRC (1989) sugere que pelo menos um terço da MS total da dieta deve ser fornecido por feno de fibra longa ou seus equivalentes (silagens picadas com tamanho de partículas médio ou grosseiro). A nova edição do NRC (2001) sugere que a FDN da dieta deve aumentar quando o tamanho médio de partículas da forragem for menor do que $3 \mathrm{~mm}$ porém, devido à insuficiência de dados para quantificar esta relação, o aumento na porcentagem da FDN na dieta não foi estabelecido. Portanto, para o balanceamento de dietas para vacas em lactação, efetividade da fonte de fibra dever ser considerada em conjunto com a composição química do alimento.

A efetividade da fibra foi definida por Grant (1997) como a habilidade deste componente dos alimentos em estimular a mastigação ou teor de gordura do leite e, ou, produção de leite corrigida. Assim, características dos alimentos que afetem a produção de saliva (fluxo de tamponantes para o rúmen) e perfil de fermentação no rúmen ( $\mathrm{pH}$ e ácido graxos voláteis) podem, direta ou indiretamente, estar relacionados àefetividade.

Nas forragens a efetividade da fibra depende principalmente da fonte e, ou, composição de FDN, tamanho de partículas e capacidade de troca catiônica. Subprodutos fibrosos, também conhecidos como bntes de fibra não forragem (FFNF), freqüentemente têm composição química semelhante a de forragens mas diferem em efetividade da fibra e respostas de desempenho quando fornecidos para ruminantes. A maioria das FFNF têm particulas de tamanho inferior ao de forragens, o que determina uma efetividade mais baixa da FDN para este grupo de alimentos. A semente de algodão representa uma 
exceção a esta regra e, em geral, tem a efetividade da FDN próxima a de forragens.

A efetividade da fibra de vem sendo avaliada com base em respostas observadas nos animais. A atividade de mastigação tem sido uma das medidas mais utilizadas para esta finalidade porque afeta diretamente a secreção de saliva, a trituração de partículas, a fermentação ruminal (pH e AGV) e o consumo de matéria seca (Colenbrander et al. (1991). A porcentagem de gordura no leite também vem sendo utilizada como critério para avaliar à efetividade de fibra porque a sua depressão tem sido tradicionalmente associada à dietas com porcentagem baixa de forragem ou à utilização de forragens com partículas de tamanho reduzido. Entretanto, é preciso ter cuidado ao se avaliar efetividade com base no teor de gordura no leite porque seu teor pode ser afetado por outros fatores da dieta e não apenas pelo teor de fibra. Nas avaliações de efetividade da fibra de FFNF, o julgamento baseado na habilidade para estimular à mastigação forneceu medidas de efetividade muito inferiores às obtidas considerando o teor de gordura no leite. Como resultado, seria importante também pesquisar outros fatores, além da atividade de mastigação e porcentagem de gordura no leite, para avaliar o meio ambiente ruminal e determinar que impactos alterações na dieta teriam sobre o padrão de fermentação ruminal.

A formação de uma camada flutuante de partículas grandes no rúmen é fundamental para reter partículas de fibra potencialmente digestível, regular a passagem de alimentos e estimular à ruminação. A espessura e compactação desta camada, denominada de "mat", também está sendo usada como medida auxiliar para avaliar a efetividade da fibra (Weidner \& Grant, 1994b). Welch (1982) desenvolveu a metodologia para avaliar a consistência do "mat", baseada na ascensão de um peso inserido no saco ventral do rúmen e submetido à força constante de um peso externo. O tempo de ascenção polongado deste peso é indicativo de espessura maior e empacotamento mais rígido (compactação) da camada flutuante de digesta ruminal. Por outro lado, 
um tempo reduzido de ascenção é indicativo de espessura menor e empacotamento menos rigido desta camada. Assim, associada à outras medidas (teor de gordura no leite e tempo de mastigação), a consistência do "mat" ajuda àexplicar melhor variações de efetividade da fibra.

As forragens tem papel fundamental na nutrição de bovinos como fontes de energia de baixo custo e fornecedoras da fibra necessária à manutenção da função ruminal, consumo de MS, produção e composição do leite. Em dietas típicas de bovinos leiteiros, a maior parte da FDN é proveniente de forragem porém, sua inclusão na dieta depende da sua disponibilidade, concentração e composição da FDN e formas de processamento (tamanho de partículas). Quando as forragens possuem tamanho de partícula adequado, o NRC (2001) sugere que as dietas de vacas em lactação devem ser balanceadas com, no mínimo, $25 \%$ de FDN total e $19 \%$ de FDN proviente de forragem (FDNF) porém, também sugere que a FDN total deve aumentar quando as forragens são excessivamente picadas. Deste modo, o NRC (2001) reconhece a importância do tamanho de partícula de forragens na estimulação da atividade de mastigação, secreção de saliva e estabilidade da função ruminal.

Os subprodutos representam fontes valiosas de proteína, energia e fibra para a indústria de produção animal. Tradicionalmente, subprodutos tem sido usados como suplementos energéticos e, ou, protéicos, embora o valor destes alimentos como fontes de fibra tenha sido pesquisado recentemente. $\mathrm{O}$ uso de subprodutos como fontes de fibra representa uma opção valiosa para rações que podem ser limitadas pela quantidade ou qualidade da fibra das forragens. Quando os subprodutos são usados para substituir forragens, a porcentagem de FDNF da dieta pode diminuir e a FDN total aumentar para, neste caso, compensar a efetividade menor da fibra de subprodutos. Esta estatégia é adotada pelo NRC (2001), onde cada unidade percentual de redução na FDNF deve ser compensada pelo aumento de duas unidades percentuais de FDN total na dieta. Portanto, nesta situação considera-se que a FND de FFNF (subprodutos) tem $50 \%$ da efetividade atribuída æ̀̀ forragens. Além disso, o 
NRC (2001) também estabelece um limite mínimo de 15\% para FDNF. Estas propostas foram baseadas em respostas observadas no teor de gordura do leite, $\mathrm{pH}$ do fluído ruminal, atividade de mastigação e digestilidade da fibra quando FFNF substituem forragens como fontes de fibra. O tamanho de partículas e gravidade específica são duas características que diferenciam as FFNF de forragens e podem influenciar as respostas de efetividade observadas. 


\section{REVISÃO DE LITERATURA}

\subsection{Caracterização da fração fibra}

Fibra é um componente essencial da dieta de vacas em lactação necessário para obtenção de consumo máximo de matéria seca (MS) e energia, para manter normal a fermentação no rúmen e porcentagem de gordura do leite, e ajudar na prevenção de desordens metabólicas do pós-parto (NRC, 1989). O conteúdo de fibra da dieta pode ser avaliado utilizando-se os métodos da FB, FDN ou FDA. A fibra bruta isola os componentes fibrosos de plantas resistentes à degradação em soluções ácidas e alcalinas. Esta metodologia tem como objetivo isolar componentes fibrosos menos digestíveis e estruturais de plantas, entretanto, as recuperações de componentes da parede celular (lignina, hemicelulose e celulose) são inconsistentes (Van Soest, 1994). Os componentes insolúveis da parede celular de plantas podem ser isolados com solução de detergente neutro para determinar a concentração de FDN, a qual inclui celulose, hemicelulose e lignina, além de nitrogênio e cinza insolúveis em detergente neutro. A solução de detergente ácido isola os componentes de FDA da parede celular, celulose e lignina, além de nitrogênio e cinza insolúveis em detergente ácido.

Atributos físicos da fonte de fibra (tamanho de partícula) são também utilizados para avaliar alimentos. O NRC (1989) sugere que pelo menos um terço da matéria seca total da dieta deve ser fornecido através de feno de 
fibra longa ou seus equivalentes (silagens picadas com tamanho de partícula médio ou grosseiro). Além disso, o NRC (1989) também sugere que dietas de vacas em lactação devem ser balanceadas com, no mínimo, 25 a $28 \%$ de FDN total e $75 \%$ da FDN da dieta dever ser suprido por forragens. No entanto, a quantidade de FDN total incluída na dieta pode ser variável dependendo de fatores relacionados à vaca (estágio da lactação, produção de leite e escore de condição corporal), ao manejo (frequência de alimentação e sistema de oferta de alimentos), aos alimentos (tamanho de partícula das forragens, poder tampão dos alimentos e fonte de fibra) e também fatores econômicos.

No balanceamento de dietas para vacas em lactação, é importante considerar a efetividade da fonte de fibra em conjunto com a composição química do alimento. Subprodutos fibrosos, também conhecidos com fontes de fibra não forragem (FFNF), freqüentemente têm composição química semelhante àde forragens mas diferem na efetividade da fibra e respostas que determinam quando fornecidos para ruminantes. A efetividade de uma fonte de fibra pode ser definida como a habilidade deste componente dos alimentos em estimular a mastigação ou teor de gordura do leite e produção de leite corrigida, ou ambos (Grant, 1997). O tamanho de partículas é relacionado à efetividade; forragens que são processadas com tamanho de partículas pequeno diminuem o tempo de mastigação, reduzindo à secreção de saliva e pH do fluído ruminal (NRC, 1989). Em conjunto, estas respostas resultam na depressão do teor de gordura do leite.

Vários fatores de resposta do animal tem sido utilizados para avaliar a efetividade da fibra de diferentes alimentos. Estes fatores incluem o consumo de MS, mudanças no meio ambiente ruminal $(\mathrm{pH}$, produção de AGV e relação acetato:proprionato $\left(\mathrm{C}_{2}: \mathrm{C}_{3}\right)$, teor de gordura no leite, tempos de mastigação e ruminação e consistência do "mat"). Outra medida da efetividade da fibra é a fibra fisicamente efetiva (FDNfe). A FDNfe é a fração do alimento que estimula a mastigação, sendo os valores de efetividade física determinados para o 
alimento como o produto da concentração de FDN multiplicada por um fator de efetividade física determinado pelo tempo de mastigação (Grant, 1997).

\subsection{Efetividade baseada na atividade de mastigação}

O tempo de mastigação tem sido uma das medidas mais estudadas e utilizadas para avaliar a efetividade da fibra por causa dos efeitos que ela tem sobre a secreção de saliva, processo de trituração de alimentos, consumo de MS, função ruminal ( $\mathrm{pH}$ e perfil de AGV) e porcentagem de gordura no leite (Colenbrander et al., 1991). Vacas em lactação podem produzir $308 \mathrm{~L}$ de saliva/d durante a mastigação (Cassida e Stokes, 1986). A secreção de saliva é o mecanismo mais importante para remoção dos íons hidrogênio que são produzidos durante a fermentação ruminal dos alimentos e a remoção destes íons hidrogênio é fundamental para manutenção do $\mathrm{pH}$ ruminal. $\mathrm{O} \mathrm{pH}$ ruminal baixo tem sido associado à redução do apetite, da motilidade ruminal, da produção microbiana e da digestão de fibra (Allen, 1997). A saliva contém íons bicarbonato e fosfato que ajudam na remoção de íons hidrogênio através da alcalinização (aumento do $\mathrm{pH}$ ruminal) e tamponamento (resistência àvariações de $\mathrm{pH}$ ). O sistema bicarbonato remove íons hidrogênio através da desidratação do ácido carbônico, em uma reação que produz água e dióxido de carbono. O sistema fosfato remove íons hidrogênio na forma de dihidrogênio fosfato. Allen (1997) compilou os resultados de literatura nos quais o tempos de mastigação foram reportados e desenvolveu uma série de equações para predição do tempo de mastigação e fluxo de saliva baseados no consumo de MS, FDNF, FDN total e tamanho de partícula. Estas equações podem ser utilizadas para prever a capacidade tampão da dieta, a qual pode ser útil na predição do $\mathrm{pH}$ ruminal.

O tempo de mastigação é relacionado ao consumo de MS e concentração de FDN da dieta. Sudweeks et al. (1980) observou que o tempo 
total de mastigação e ruminação aumentavam com o aumento no consumo de MS. Dado e Allen (1995) observaram que quantidades adicionais de FDN ou a inserção de volumes inertes no rúmen (recipientes de plástico de $500-\mathrm{mL}$ preenchidos com água) aumentavam o tempo de mastigação por unidade de MS ou FDN. Beauchemin e Buchanan-Smith (1989) detectaram resposta quadrática nos tempos de mastigação e ruminação quando a concentração de FDN na dieta aumentava (26, 30 e 34\% FDN). O tempo total de mastigação também aumentou linearmente quando Beauchemin (1991) forneceu dietas com três concentrações de FDN para vacas em lactação.(31, 34 e 37\%). Entretanto, quando o tempo de mastigação foi expresso em relação ao consumo, notou-se um descréscimo linear no tempo de ruminação ( $\mathrm{min} / \mathrm{kg}$ de FDN e min/kg de FDNF) quando a concentração de FDN da dieta aumentava. Embora existam variações entre experimentos, a concentração de FDNF aparentemente é o melhor preditor do tempo de mastigação (minutos por dia ou minutos por $\mathrm{kg}$ de MS). Utilizando médias de dados publicados na literatura ( $n=33$ ), Armentano \& Pereira (1997) calcularam coeficientes de correlação de 0,63 e 0,81 para relação entre FDNF (\% da MS) e medidas da ativitidade de mastigação ( $\mathrm{min} / \mathrm{d}$ e $\mathrm{min} / \mathrm{kg}$ de MS, respectivamente).

Sudweeks et al. (1981) desenvolveram um índice de valor de forragem para estimar o tempo de mastigação ( $\mathrm{min} / \mathrm{kg}$ de MS) baseados no consumo de MS, concentração de FDN (\% da MS) e tamanho de partículas. Welch e Smith (1971) observaram que o tempo de ruminação aumentava quando partículas de $5 \mathrm{~cm}$ de polipropileno foram inseridas no rúmen de ovinos ou novilhos. De forma semelhante, Santini et al. (1983) também observaram que o tempo total de mastigação aumentava com o aumento no tamanho de partículas. Relação semelhante também foi notada quando ambos, tempo de ruminação e mastigação, foram ajustados para o consumo de MS ou forragem. Grant et al. (1990) forneceram rações completas contendo silagem de alfafa com três tamanhos de partículas para vacas em lactação e observaram que o aumento tamanho de partículas das silagens também proporcionava aumento nos 
tempos totais de ruminação e mastigação. Resultados semelhantes foram também obtidos quando o fenos de alfafa com três tamanhos de partículas foram incluídos em rações completas de vacas em lactação (Grant, 1990).

Os efeitos do tamanho de partículas e concentração de FDN sobre o tempo de mastigação não têm sido consistentes entre trabalhos. Colenbrander et al. (1991) forneceram silagens de alfafa picadas para dois tamanhos de corte e duas concentrações de FDN (21,5 e 31,9\%). As silagens picadas com tamanho menor de partícula e concentração menor de FDN reduziram em 50\% $(6,2 \mathrm{~h})$ o tempo de mastigação quando comparadas com as silagens picadas com tamanho maior de partícula e concentração maior de FDN. Santini et al. (1983) estimaram em $1,0 \mathrm{~cm}$ o ponto abaixo do qual o tamanho de partículas afetou o tempo total de mastigação. Em avaliação recente conduzida por Allen (1997), o tamanho de partículas de $0,3 \mathrm{~cm}$ foi apontado como limite para respostas no tempo de mastigação associadas ao tamanho de partículas. $O$ aumento no tamanho de partículas além de $0,3 \mathrm{~cm}$ aumenta o tempo de mastigação porém, em taxas decrescentes. Por exemplo, o aumento no tamanho de partículas de 0,3 para $0,4 \mathrm{~cm}$ não proporciona incremento no tempo do mastigação de mesma magnitude observada quando há aumento no tamanho médio de partículas de 0,2 para 0,3 cm.

\subsection{Quantificação da efetividade}

O tempo de mastigação pode ser usado para calcular os valores de efetividade física da fibra dos alimentos e compará-los entre si. Mooney \& Allen (1997) apresentaram uma série de equações, baseadas na concentração de

FDN e tempo de mastigação, as quais foram utilizadas para calcular a efetividade física da fibra da silagem de alfafa e semente de algodão. Este método considerou o conteúdo de FDN do alimento e tempo de mastigação proporcionado por cada componente da dieta. A contribuição dos concentrados 
para mastigação foi assumida com sendo igual a zero, embora Mertens (1997) tenha estimado valores de efetividade tão altos quanto 0,94 para 0 milho triturado grosseiramente. Outra suposição adicional, baseada na regressão de médias para tratamentos publicadas na literatura, foi que o tempo basal de mastigação seria de $355 \mathrm{~min} / \mathrm{d}$ para dietas com 0\% de FDN (Mooney \& Allen, 1997). Os valores de efetividade física dos alimentos testados foram calculados dividindo-se o tempo de mastigação por unidade de FDN do alimento teste pelo tempo de mastigação por unidade de FDN de silagem de alfafa.

O método desenvolvido por Mooney \& Allen (1997) assume que há uma resposta linear do tempo de mastigação em relação ao aumento na concentração de FDN da dieta. Embora a linearidade desta resposta não tenha sido desafiada, existem evidências para sugerir que a resposta ao incremento de FDN na dieta não é linear (Beauchemin, 1991; Grant, 1997; Woodford e Murphy, 1988). Grant (1997) notou que a ruminação por unidade de FDNF consumido aumentou quando a concentração de FDN da dieta diminuiu, sugerindo que vacas possuiam um mecanismo adaptativo de aumento na eficiência de ruminação quando o consumo de fibra efetiva era limitado. Woodford \& Murphy (1988) haviam comprovado à existência deste mecanismo quando reduziram a quantidade de forragem de fibra longa na dieta, ao substituírem à silagem de alfafa por alfafa peletizada. Assumindo que o tamanho de partículas da alfafa peletizada era insuficiente para estimular a mastigação e, então, somente a silagem de alfafa a estimularia, eles observaram que a eficiência de mastigação ( $\mathrm{min} / \mathrm{kg}$ de MS) aumentava quando a quantidade de silagem de alfafa na ração diminuia. Estes autores postularam que vacas possuiam um mecanismo adaptativo (aumento na eficiência de mastigação ou no número de movimentos mastigatórios por kg de FDNF) para corrigir baixo $\mathrm{pH}$ ruminal, aumentar a passagem de partículas e fluídos através do rúmen e, ou, diminuir a taxa pela qual a ruminação seria deprimida quando o consumo de fibra efetiva diminui. Quando três teores de FDN dietético (31, 34 e $37 \%$ ) foram fornecidos para vacas em lactação, o tempo de ruminação (min/kg 
de FDN e min/kg de FDNF) diminuiu linearmente quando a concentração de FDN na dieta aumentava(Beauchemin, 1991).

Mertens (1997) desenvolveu um sistema e atribuiu valores de fibra fisicamente efetiva para alimentos baseado na concentração de FDN e tamanho de partículas. Um separador de partículas por tamanho de movimentos verticais foi usado para separar as partículas do alimentos com base no diâmetro. A proporção de partículas que foram retidas em peneira de $1,18 \mathrm{~mm}$ foi multiplicada pela concentração de FDN do alimento para gerar um fator de efetividade física (FDNfe) (Mertens, 1997). Partículas menores do que 1,2 mm em diâmetro passariam pelo rúmen rapidamente, proporcionando pouco ou nenhum estímulo para ruminação (Mertens, 1997). Através deste sistema, o qual quantifica a proporção de partículas maiores do que $1,18 \mathrm{~mm}$, seria possível estimar a fração do alimento que ficaria retida no rúmen e estimularia a ruminação. $O$ desenvolvimento deste método foi baseado em três suposições: 1) A FDN dos alimentos seria distribuída uniformemente em todas as frações, independente do tamanho de partículas, 2) A atividade de mastigação também seria igual para todas as particulas retidas na peneira de $1,18 \mathrm{~mm}$, e 3) A fragilidade das partículas (facilidade para redução no tamanho) não seria diferente entre fontes de FDN (Mertens, 1997). Estes sistema usou como padrão de referência teórica um feno de gramínea de partículas longas, contendo $100 \%$ de FDN, para o qual foi atribuído o valor de FDN fisicamente efetiva (FDNfe) igual a 1,0. Utilizando resultados prévios de pesquisas, Mertens (1997) notou que havia uma relação curvilínea positiva entre os valores de FDNfe e $\mathrm{pH}$ ruminal $\left(\mathrm{pH}\right.$ ruminal $\left.=6,67-0,143(1 / \mathrm{peFDN}) ; \mathrm{r}^{2}=0,71\right)$ e entre os valores de FDNfe e porcentagem de gordura no leite (Gordura no leite $(\%)=$ $4,32-0,171(1 /$ peFDN $\left.) ; r^{2}=0,63\right)$. 


\subsection{Uso da porcentagem de gordura no leite para quantificar efetividade}

A depressão no teor de gordura do leite tem sido tradicionalmente associada à dietas com porcentagem baixa de forragem ou utilização de forragens excessivamente picadas. Em dois trabalhos, a porcentagem de gordura no leite aumentou linearmente em resposta a concentração de FDN na dieta (Beauchemin, 1991; Beauchemin e Buchanan-Smith, 1989). O aumento na relação volumoso:concentrado $(\mathrm{V}: \mathrm{C})$ da dieta também resultou em aumento na porcentagem de gordura no leite (Robinson e McQueen, 1997; Santini et al., 1983). No entanto, a concentração de FDN não afetou a porcentagem de gordura no leite em outros trabalhos (Colenbrander et al., 1991; Dado e Allen, 1995). Além disso, o decréscimo no tamanho de partículas da forragem tem afetado negativamente a porcentagem de gordura no leite em alguns trabalhos (Grant et al., 1990a; Grant et al., 1990b) porém, não mostrou este mesmo efeito em outros (Beauchemin e Buchanan-Smith, 1989, Colenbrander et al., 1991; Santini et al., 1983).

Quando FFNF são incluídas nas dietas de vacas em lactação, o conteúdo de forragem da dieta freqüentemente diminui e, muitas vezes, a porcentagem de gordura no leite é alterada. Deste modo, a porcentagem de gordura no leite tem sido utilizada para atribuir valores de efetividade da fibra dos alimentos, permintindo comparações entre alimentos. Para estas comparações, o método denominado de "slope ratio" tem sido freqüentemente utilizado (Clark \& Armentano, 1993). Neste método, a resposta na porcentagem de gordura no leite é medida nas dietas que incluem os alimentos a serem testados e comparada à resposta encontrada na dieta que contém o alimento referência (na maioria dos casos, feno ou silagem de alfafa). A variação na porcentagem de gordura no leite é dividida pela variação na porcentagem de FDN para gerar coeficientes de regressão. Também é assumido que a FDN da silagem de alfafa é $100 \%$ efetiva, para qual é atribuido um coeficiente de 
efetividade igual a 1,0. Para atribuir valores de efetividade aos alimentos testados, os coeficientes destes alimentos são comparados ao coeficiente obtido para silagem ou feno de alfafa (referência). Por exemplo, se em uma avaliação com vacas em lactação um alimento como grãos de destilaria desidratados gerasse um coeficiente de regressão linear de 0.020 e a silagem de alfafa um coeficiente de 0,025 , o valor calculado de efetividade dos grãos de destilaria desidratados seria de $0,8(0,020 / 0,025)$; então, os grãos de destilaria teriam $80 \%$ da efetividade da silagem de alfafa, quando considerada a manutenção da porcentagem de gordura no leite (Clark \& Armentano, 1993).

Este método assume que há relação linear entre a concentração de gordura no leite e porcentagem de FDN na dieta e também não considera diferenças que ocorrem na qualidade ou efetividade da fibra da silagem alfafa entre trabalhos diferentes. Além disso, a porcentagem de gordura no leite pode ser afetada por outros fatores da dieta e não apenas pelo teor de FDNF. Entre estes fatores podem ser citados a relação $\mathrm{V}: \mathrm{C}$, a composição de carboidratados dos concentrados, tipo e concentração de lipídios do alimentos, consumo de MS e frequência de alimentação (Sutton, 1989). Armentano \& Pereira (1997) compilaram e avaliaram os dados de 27 experimentos publicados na literatura nos quais a concentração de FDN variava em função de mundanças na relação V:C ou qualidade de forragem e pelo menos $70 \%$ da FDN da dieta era proveniente de forragem. Este autores calcularam que a correlação entre a porcentagem de gordura no leite e porcentagem de FDNF era de 0,40 .

\subsection{Atividade de mastigação versus porcentagem de gordura no leite como critérios de resposta.}

É importante considerar critérios mútiplos de resposta para avaliação da efetividade da fibra. Armentano \& Pereira (1997) compilaram e avaliaram dados de trabalhos publicados na literatura que consideravam atividade de mastigação 
e, ou, porcentagem de gordura no leite como respostas para medir a efetividade da fibra. Eles concluíram que o julgamento de FFNF baseado na habilidade para estimular mastigação fornecia medidas muito inferiores de efetividade do que poderiam ser justificadas pela resposta observada na porcentagem de gordura no leite. No entanto, Mertens (1997) sugeriu que os fatores de efetividade baseados na gordura no leite, ao invés de atividade de mastigação, foram indicadores menos sensíveis do valor de fibra a ser usado para prevenir depressão no consumo de MS, acidose ruminal subclínica, lamenite ou deslocamento de abomaso. Clark \& Armentano (1993) também alertaram que a porcentagem de gordura no leite não deveria ser utilizada como critério único de avaliação de efetividade porque alguns alimentos foram efetivos para manter a porcentagem de gordura no leite mas não estimularam da mesma forma a mastigação e, portanto, não está claro se dietas que impedem ou controlam a depressão na porcentagem de gordura mantêm um meio ambiente ruminal saudável e então previnem desordens metabólicas e digestivas. Parece não haver relação clara entre FFNF que aumentam a atividade de mastigação e aquelas que tem como impacto principal alterações na porcentagem de gordura (Swain \& Armentano, 1994). Deste modo, seria importante pesquisar também outros fatores, além da atividade de mastigação e porcentagem de gordura no leite, para avaliar o meio ambiente ruminal e determinar a importância que alterações na dieta teriam sobre o padrão de fermentação ruminal, $\mathrm{pH}$ e consistência do "mat" ruminal.

\subsection{Efetividade e o meio ambiente ruminal}

A efetividade física é relacionada à natureza bifásica do conteúdo ruminal, o qual é formado uma camada flutuante de partículas longas sobre um "pool" de líquidos e particulas pequenas (Mertens, 1997). A formação desta camada flutuante e estável ("mat”) retém as partículas que contêm fibra 
potencialmente digestível e, através de filtração e entrelaçamento, altera a dinâmica de fermentação e passagem e contribui para estimular a ruminação (Mertens, 1997).

Welch (1982) desenvolveu a metodologia para avaliar a consistência do "mat", baseada na ascensão de um peso inserido no saco ventral do rúmen e submetido à força constante de um peso externo. O tempo de ascenção polongado do peso interno é indicativo de espessura maior e empacotamento mais rígido (compactação) da camada flutuante de digesta ruminal. Por outro lado, um tempo reduzido de ascenção é indicativo de espessura menor e empacotamento menos rigido desta camada. Assim, associada à outras medidas (teor de gordura no leite e tempo de mastigação), a consistência do "mat" ajuda à explicar melhor variações de efetividade da fibra ( Allen \& Grant, 2000; Weidner \& Grant, 1994).

Welch (1982) avaliou a consitência do "mat" de novilhos alimentados com feno de gramínea, silagem de milho, alfafa peletizada e feno ou uma mistura de $80 \%$ de concentrados e $20 \%$ de feno de gramínea. Embora a massa de conteúdo ruminal não tenha diferido entre tratamentos, os novilhos consumindo feno de gramínea tinham espessura maior da camada flutuante e tempo maior de ascenção, quando comparados à novilhos alimentados com silagem de milho, alfafa peletizada ou dieta com proporção elevada de concentrados. Os novilhos consumindo alfafa peletizada ou proporção elevada de concentrados tinham tempos de ascenção menores, menor espessura e rigidez da camada flutuante.

O meio ambiente ruminal é afetado pela composição da dieta. Conforme já discutido previamente, dietas que não estimulam adequadamente a mastigação reduzem a produção de saliva, o que resulta em $\mathrm{pH}$ ruminal mais baixo, podendo comprometer a digestibilidade da fibra (Grant \& Mertens, 1992). Em uma revisão, Erdmam (1988) demonstrou que a digestibilidade "in vivo" da FDA aumentava, em média, 3,6 unidades percentuais para cada 0,1 unidade de aumento no $\mathrm{pH}$ do fluído ruminal. $\mathrm{O} \mathrm{pH}$ ruminal baixo também tem sido 
associado ao decréscimo na biohidrogenação de ácidos graxos (Kalscheur et al., 1997). Gaynor et al. (1995) notaram que a redução na biohidrogenação de ácidos graxos trans- $\mathrm{C}_{18: 1}$ para ácido esteárico aumenta o fluxo de ácidos trans$\mathrm{C}_{18: 1}$ para o duodeno, o que tem sido associado com a depressão do teor de gordura no leite.

Além disso, o pH ruminal baixo afeta a taxa fracional de absorção de AGV. Quando o pH decresce abaixo da neutralidade, a taxa de absorção dos ácidos propiônico e butírico aumenta mas não há efeito sobre a taxa de absorção de ácido acético (Allen, 1997). Estes ácidos têm constantes de dissociação semelhantes, mas, por causa da taxa de absorção menor, o ácido acético tem efeito maior na redução do $\mathrm{pH}$ ruminal do que os ácidos propiônico e butírico (Allen, 1997). Além disto, o pH ruminal baixo altera a fermentação no rúmen, afetando o perfil de AGV no fluído ruminal (Mertens, 1997).

O aumento na concentração de propionato no rúmen tem sido associado à eventos metabólicos que resultaram na redução da porcentagem de gordura no leite e deram origem a teoria glucogênica da depressão na porcentagem de gordura no leite (Gaynor et al., 1995). A relação acetato:propionato $\left(\mathrm{C}_{2}: \mathrm{C}_{3}\right)$ tem sido utilizada para avaliar a fermentação ruminal e o declínio maior na porcentagem de gordura no leite tem sido observado quando a relação $\mathrm{C}_{2}: \mathrm{C}_{3}$ decresce para <2,0 (Erdman, 1988).

$\mathrm{O}$ aumento na concentração de fibra da dieta tem sido associado ao aumento da relação $C_{2}: C_{3}$ (Beauchemim, 1991). Dado e Allen (1995) observaram que a porcentagem de ácido aumentava e de proprionato diminuia com a inclusão de material inerte no rúmen (recipientes plásticos de 500-ml preenchidos com água) ou fibra na dieta. Apesar da relação $\mathrm{C}_{2}: \mathrm{C}_{3}$ aumentar com a adição de material inerte ou fibra, a concentração de fibra teve um impacto maior do que o material inerte.

É evidente que o meio ambiente ruminal respresenta um sistema complexo e variável. Métodos que avaliem um alimento baseado em uma única resposta, tais como porcentagem de gordura no leite, mastigação, consistência 
do "mat", $\mathrm{pH}$ ruminal ou relação $\mathrm{C}_{2}: \mathrm{C}_{3}$, apresentam falhas para descrever adequadamente a resposta animal. Assim, medidas simultâneas devem ser consideradas para predizer à resposta de animais que recebem dietas semelhantes.

\subsection{Forragens como fonte de fibra efetiva}

\subsubsection{Tamanho de partículas e efetividade da fibra}

As forragens tem papel fundamental na nutrição de bovinos como fontes energia de baixo custo e fornecedoras da fibra necessária à manutenção da função ruminal, consumo de $\mathrm{MS}$, produção e composição do leite. A porcentagem de forragem incluída na dieta de vacas em lactação depende de inúmeros fatores tais como: disponibilidade, formas de processamento, concentração e composição FDN. As forragens têm concentração de fibra elevada e a disponibilidade ou digestibilidade da FDN nestes alimentos depende do tipo de planta (gramíneas ou leguminosas), estágio de maturidade e grau de processamento (tamanho de partículas) (Nussio et al, 2000). A composição e digestibilidade da FDN podem, até certo ponto, ser manipuladas pela escolha de híbridos ou variedades com maior digestibilidade da FDN, pelo estádio de maturidade da planta no momento da colheita ou através de tratamentos químicos que alterem a composição ou melhorem capacidade de microrganismos do rúmen para colonizar e digerir a fibra no rúmen.

A manipulação da digestibilidade da FDN é importante para obtenção de desempenho sastifatório pois a redução na digestibilidade da fibra pode limitar o consumo e conseqüentemente produção. Quando há redução na digestibilidade da fibra, o valor de enchimento ("fill") da dieta aumenta e pode alcançar o limite físico de ingestão, restringindo assim o consumo. A importância da digestibilidade da FDN de 13 grupos de forragens para o consumo de MS e 
desempenho de vacas em lactação foi avaliada por Oba \& Allen (1999). Estes autores concluíram que o aumento na digestibilidade da FDN de forragem também aumenta o consumo de MS e produção de leite e, cada aumento de uma unidade percentual de digestibilidade "in vitro" ou "in situ" da FDN foi associado ao aumento de $0,17 \mathrm{~kg} / \mathrm{d}$ no consumo de $M S$ e de $0,25 \mathrm{~kg} / \mathrm{d}$ na produção de leite.

O NRC (2001) considera que a porcentagem mínima de FDN na dieta é necessária para manter a função rumimal e saúde dos animais. A concentração de FDN na dieta é diretamente relacionada ao $\mathrm{pH}$ ruminal porque os carboidratos estruturais (celulose e hemicelulose) são fermentados mais lentamente no rúmen do que os carboidratos não estruturais, diminuindo assim a produção de AGV no rúmen. Além disso, em dietas típicas de bovinos leiteiro grande parte da FDN é proveniente de forragens que têm estrutura física (tamanho de partículas) adequada para estimular a mastigação e consequentemente, a secreção de saliva.

Quando as forragens são picadas com tamanho de partículas adequado, o NRC (2001) sugere que dietas de vacas em lactação devem ser balanceadas para, no mínimo, 25\% de FDN total e 19\% de FDNF. Embora não defina uma porcentagem, o NRC (2001) também sugere que a FDN total deve aumentar quando as forragens são picadas finamente. A importância do tamanho de partícula de forragens para manter a atividade de mastigação foi avaliada por Sudweeks et al (1981). Estes autores compararam a silagem de milho em três graus de picagem (grosseira, média e fina) e observaram que entre a picagem média e fina houve redução de 33\% na atividade de mastigação. Para o feno de alfafa, o mesmo grupo de autores observou que a atividade mastigação era reduzida em 28 e 17\%, respectivamente, quando compararam o feno longo ao picado e o feno picado ao peletizado.

O conceito de fibra fisicamente efetiva (FDNfe) foi introduzido por Mertens (1997). O valor de FDNfe dos alimentos depende principalmente de propriedades físicas (tamanho de partículas) e químicas (concentração de FDN) 
dos alimentos que estimulam a mastigação e estabeleçam a estratificação bifásica do conteúdo ruminal ("mat”). Para estabelecer valores de FDNfe para vários alimentos, Mertens (1997) considerou como padrão uma forragem hipotética (feno longo de gramínea com 100\% de FDN) contra o qual todos os demais alimentos foram comparados quanto capacidade de estimular a mastigação. Considerando este critério de avaliação, os valores de efetividade física da FDN das silagens de gramínea, milho e alfafa de picadas grosseira vairam de 0,90 a 0,95 . Para forragens picadas finamente, a efetividade física foi estimada em 0,7 a 0,85. A partir destes dados, ficou evidenciado que a efetividade física da FDN de forragens depende do tamanho partículas.

A importância do tamanho de partícula de forragens para efetividade física da fibra foi avaliada em alguns estudos (Bal et al. 2000; Bezerra at al., 2002; Clark \& Armentano, 1999; De Boever et al., 1993a; De Boever et al., 1993b; Mooney \& Allen, 1997; Schawb et al., 2002; Soita et al. 2000). A importância de fatores químicos (MS, FB, FDN, FDA, lignina e açúcares), físicos (tamanho médio de partículas, resistência a trituração e densidade) e biológicos (digestilidade "in vitro") para efetividade física da FDN de 19 silagens de gramíneas temperadas foi avaliada por De Boever et al.(1993a). Neste estudo, três tamanhos teóricos de corte (fino $=3,5 \mathrm{~mm}$; grosseiro $=24 \mathrm{~mm}$ e longo $>24$ $\mathrm{mm}$ ) foram avaliados durantes três anos consecutivos; os autores mostraram que a contribuição do tamanho partículas para explicar variações no índice de mastigação (min/kg de MS) foi apenas marginal.

De Boever et al. (1993b) estudaram também, durante três anos consecutivos, os mesmos fatores químicos, físicos e biológicos descritos anteriormente para avaliar efetividade física da FDN de 14 silagens de milho. $O$ equipamento utilizado para colheita foi ajustado para tamanhos teóricos corte de 4, 8 e $16 \mathrm{~mm}$ e, para determinar da distribuição de partículas por tamanhos foram usadas peneiras com orifícios de 9,$51 ; 4,76 ; 3,35$ e 2,38 mm, sendo a fração menor do que 2,38 $\mathrm{mm}$ recolhida em uma bandeja. $O$ índice de ingestão ( $\mathrm{min} / \mathrm{kg}$ de MS) nas silagens com $16 \mathrm{~mm}$ foi maior do que nas silagens com $4 \mathrm{e}$ 
$8 \mathrm{~mm}$, que não diferiram entre si. Para o índice de ruminação (min/kg de $\mathrm{MS}$ ), as silagens com $4 \mathrm{~mm}$ foram inferiores के silagens com 8 e $16 \mathrm{~mm}$. Assim, 0 índice mastigação, que representava a combinação dos índices de ingestão e ruminação, aumentou continuamente entre os tamanhos teóricos de corte de 4 a $16 \mathrm{~mm}$. Além disso, quando fatores químicos, físicos e biológicos foram utilizados para derivar equações de predição dos índices de ruminação e mastigação, a digestibilidade "in vitro" e a fração de partículas retidas na peneira acima de 2,38 $\mathrm{mm}$ foram os principais determinantes destes índices.

A efetividade da fibra da silagem alfafa com dois tamanhos de corte $(11,4$ e 5,8 $\mathrm{mm}$ ) foi avaliada por Mooney \& Allen (1997) que utilizaram doze vacas holandesas em lactação que receberam dietas com 17 e $24 \%$ de FDNF. A composição e produção de leite não foram afetadas pelo tamanho de partículas da forragem porém, os tempo de ingestão e ruminação aumentaram quando as vacas receberam dieta com tamanho maior de partículas.

Soita et al.(2000) utilizaram oito vacas holandesas para estudar a interação entre tamanho de partícula da forragem (4,58 mm vs. $18,75 \mathrm{~mm}$ ) e porcentagem de concentrado ( 55 vs. $45 \%$ ) sobre a atividade de mastigação e produção quando as dietas eram baseadas em grãos e silagem de cevada. Embora o consumo de MS e teor de gordura no leite não tenham sido afetados pelo tamanho de partículas da forragem, as vacas reduziram em 90 minutos os tempos de mastigação e ruminação quando receberam forragem com tamanho de partícula menor.

Clark \& Armentano (1999) utilizaram 15 vacas holandesas recebendo dietas com 12 ou $21 \%$ de FDNF para avaliar a importância da origem da FDN (silagem pré-secada de alfafa ou silagem de milho) e tamanho de partícula da forragem (silagem de milho com tamanho médio de partículas de 2,57; 4,14; 6,53 e 8,74 mm) sobre a efetividade da fibra. Neste estudo, não foram observadas diferenças no tempo de ruminação, tempo de mastigação ou teor de gordura no leite relacionadas ao tamanho de partículas da silagem de millho. A substituição de parte da FDN da silagem pré-secada de alfafa por FDN de 
silagem de milho não afetou o tempo de ruminação porém, reduziu o tempo de ingestão e mastigação.

Os efeitos do processamento dos grãos durante a colheita e do tamanho de particulas da silagem de milho sobre o consumo de MS, produção de leite, digestão e atividade de mastigação foram avaliados por Bal et al., (2000). A forragem foi colhida para ensilagem com três tamanhos de corte $(9,5 \mathrm{~mm}, 14,5$ mm e 19,0 mm) e os grãos foram processados ou não por prensagem com rolos distanciados em $1 \mathrm{~mm}$ entre si. Neste trabalho foram utilizadas 24 vacas em início de lactação (71 dias) que receberam dietas (\% da MS) com 33,5\% de silagem de milho, $16,5 \%$ de silagem de alfafa e $50 \%$ de concentrado a base de farelo de soja e milho. O consumo de MS, produção de leite, teor de gordura no leite e atividade de mastigação não diferiram entre os tamanhos de corte, sugerindo que a efetividade da fibra não foi afetada por tamanhos médios de partículas entre $9,5 \mathrm{~mm}$ e $19,0 \mathrm{~mm}$.

O processamento dos grãos e tamanho de corte de silagens de milho foram também estudados por Schawb et al. (2002). Estes autores utilizaram 24 vacas em lactação e forneceram dietas com a mesma composição (\% da MS) utilizada por Bal et al (2000). Os grãos foram processados ou não por prensagem com rolos distanciados em $2 \mathrm{~mm}$ e a silagem foi colhida com três tamanhos de corte $(13 \mathrm{~mm}, 19 \mathrm{~mm}$ e $32 \mathrm{~mm}$ ). A produção de leite não foi afetada pelos tratamentos porém, o consumo de MS diminuiu com o aumento no tamanho de corte nas silagens com grãos processados (25,9 vs. $25,1 \mathrm{~kg} / \mathrm{d}$ ) ou não processados (26,6 vs. $25,5 \mathrm{~kg} / \mathrm{d}$ ). Neste estudo, o tempo de mastigação e efetividade física da fibra não foram afetados pelos tratamentos (processamento de grãos ou tamanho de partículas).

Segundo Shaver et al. (1988) diferenças no tamanho de partículas entre forragens são parcialmente compensadas pela mastigação durante a ingestão, reduzindo em parte o impacto do processamento de forragens (tamanhos de corte) sobre as atividade de ruminação e mastigação. Além disso, aparentemente existe um limiar no tamanho de partícula das forragens a partir 
do qual são observadas respostas significativas na atividade de mastigação. Ao avaliar dados disponíveis na literatura, Allen (1997) sugeriu que redução no tamanho de partícula das forragens de $10 \mathrm{~mm}$ para $1 \mathrm{~mm}$ diminuia a atividade de mastigação porém, de forma não linear. Neste caso, a redução mais dramática na atividade de mastigação foi observada quando o tamanho médio de partícula das forragens foi inferior a $3 \mathrm{~mm}$.

Ao analisar a importância do tamanho de particula para otimização da função ruminal, Firkins (2002) concluiu que avaliação do tamanho de partículas tem ramificações importantes a nível de fazenda para otimizar a fermentação microbiana no rúmen, mas a variabilidade observada ainda impede o uso do tamanho de partículas para definir valores de efetividade da fibra, dando suporte ao procedimento adotado pelo NRC (2001), que estabeleceu limites de fibra baseado em porcentagens minímas de FDNF e máximas de carboidratos não fibrosos.

\subsubsection{Composição da FDN e efetividade da fibra}

Além do tamanho de partícula, outros fatores relacionados à forragens podem induzir respostas na atividade de mastigação. Variações nas taxas de digestão e passagem da fibra de forragens pelo rúmen alteram o valor de enchimento ("fill") das dietas e afetam a atividade de mastigação. Quando o valor de enchimento das dietas aumenta devido à flutuações na composição e, ou, digestibilidade da fibra, os receptores de pressão encontrados no rúmen são estimulados e enviam sinais ao cérebro, indicando ser necessário aumentar a atividade de ruminação. Neste caso, a intensidade da depende da porcentagem de fibra e valor de enchimento da dieta, conforme foi demonstrado por Dado e Allen (1995). Neste trabalho, eles observaram que o aumento na concentração de FDN na dieta (35\% vs. $25 \%$ ) ou inclusão de volumes inertes no rúmen (recipientes plásticos de $500 \mathrm{~mL}$ preenchidos com água) aumentavam o tempo de mastigação ( $\mathrm{min} / \mathrm{kg}$ de MS e min/kg de FDN), o número de contrações 
reticulares durante a ruminação e taxa fracional de passagem da FDN pelo rúmen.

Seis vacas holandesas com 80 dias de lactação foram utilizadas para avaliar os efeitos de concentração de FDN da dieta e qualidade do feno de alfafa sobre a atividade de mastigação, digestibilidade e desempenho (Beauchemin, 1991). Seis dietas foram formuladas, com três concentrações de FDN total $(31,34$ e $37 \%)$ e dois fenos de alfafa, colhidos no início ou metade do período de florescimento. As porcentagens de PB, FDN e lignina para os fenos colhidos no ínicio e meio do florescimento foram de 19,4 vs. 16,$7 ; 38,8$ vs. 47,6 e 6,6 vs. 8,12, respectivamente. Para as dietas com a mesma porcentagem de FDN total, a produção e teor de gordura no leite não foram afetados pelo composição da FDN do feno de alfafa porém, com o avanço na maturidade da planta, o tempo de ruminação (min/kg de FDN) diminuiu de 55,5 (metade do florescimento) para 57,3 (início do florescimento) (Beauchemin, 1991).

A importância da fonte e composição da FDN para atividade de mastigação foram também avaliadas utilizando-se 22 vacas em lactação que receberam dietas balanceadas com $30 \%$ de FDN total e $22 \%$ FDNF de feno de alfafa ou palha de trigo (Poore et al., 1993). O consumo de MS, produção e teor de gordura no leite não foram afetados pela fonte de fibra. As taxas de passagem de fluído e ingredientes das dietas foram mais baixas nas dietas com palha de trigo porém, o tempo mastigação ou digestibilidade de fibra não foram afetados (Poore et al., 1993).

De Boever et al.(1993a) e De Boever et al.(1993b) avaliaram a importância dos fatores químicos, físicos e biológicos de silagens de gramíneas e de milho sobre os índices de ruminação e mastigação (min/kg de MS). Nas 19 silagens de gramínea houve aumento na atividade de mastigação (min/kg de FDN) com o avanço da maturidade da planta. Para De Boever et al (1993a) esta seria uma prova indireta de que a fibra torna-se mais resistente trituração quando aumenta o grau de lignificação da planta, demandando atividade maior de mastigação para redução no tamanho de partículas. Por outro lado, para a 
silagem de milho, De Boever et al. (1993b) concluiram que o tempo de mastigação praticamente constante para FDN (min/kg de FDN) e mudanças inconsistentes na concentração de lignina (\% da MS) eram indicativos de que a fibra não se tornava mais resistente à redução no tamanho de partículas com avanço da maturidade da planta.

Os efeitos da digestibilidade da FDN da silagem de milho e concentração de FDN total na dieta sobre a atividade de mastigação foram avaliados utilizando-se 8 vacas em lactação de alta produção (Oba \& Allen, 2000). As dietas foram balanceadas para 29 e $38 \%$ de FDN total e com silagens provenientes dos hibrídos $b m 3$ e isogênico normal. As digestibilidades "in vitro" da FDN das silagens após 30 horas de incubação foram de 55,9 \% para o híbrido bm3 e 46,5 \% para o híbrído isogênico normal. O consumo de MS e "turnover" ruminal de FDN aumentaram com a utilização do híbrido bm3 porém, a massa ("pool size") de FDN no rúmen e mastigação (min/kg de MS e min/kg de FDN) não foram afetados pelos híbridos utilizados. Neste caso, o aumento de consumo observado para silagem com maior digestibilidade de fibra contribuiu para manter a massa de FDN no rúmen relativamente constante e, consenqüentemente, a ativitidade de mastigação. Deste modo, os autores concluíram que não existem evidências de que o aumento na digestibilidade da FDN altere a efetividade da fibra das silagens de milho (Oba \& Allen, 2000).

A silagem de milho e cana-de-açúcar diferem na concentração e digestibilidade da FDN e, devido à lignificação menor da parede celular, a digestibilidade da fibra da silagem de milho é mais elevada do que a cana-deaçúcar, conforme foi evidenciado por Campos et al. (2001) e Mendonça et al. (2002a). Para estas forragens, a importância de diferenças na concentração e composição da FDN sobre a atividade de mastigação não vem sendo avaliada com frequência.

No Brasil, a atividade de mastigação de vacas em lactação recebendo como forragens exclusivas a silagem de milho ou cana-de-açúcar foi avaliada por Mendonça et al. (2002b). Neste experimento as vacas receberam dietas 
com 60 ou $50 \%$ de volumosos e 34 a $28 \%$ de FDN total. Os tempos de ingestão e ruminação não diferiram entre os tratamentos porém, o tempo de mastigação foi maior para dieta com silagem de milho. Neste trabalho, não foram relatados os tempos de ruminação ou mastigação por $\mathrm{kg}$ de MS ou FDN porém, o consumo de MS foi inferior nas dietas contendo cana-de-açúcar como forragem exclusiva, o que poderia afetar os resultados se estes fossem expressos por unidade de MS ou FDN consumida. A partir dos resultados apresentados pelos autores foi possível calcular os tempos de ruminação (81 vs. $101 \mathrm{~min} . / \mathrm{kg}$ de FDN) e mastigação (130 vs. 157 min./kg de FDN) para as dietas com $60 \%$ de silagem de milho ou cana-de-açúcar, respectivamente, indicando que as atividades ruminação ou mastigação aumentaram, pelo menos numericamente, quando os resultados foram expressos por unidade de FDN consumida.

A atividade de mastigação de vacas recebendo dietas com $19-20 \%$ de FDNF a partir de silagens de milho com duas texturas nos grãos ("dent" ou "flint") ou cana-de-açúcar foi também avaliada por Correa et al. (2000) que não observaram diferenças na atividade de mastigação ( $\mathrm{min} . / \mathrm{d}$ ou $\mathrm{min} / \mathrm{kg}$ de MS) quando as silagens de milho foram comparadas àcana-de-açúcar.

\subsection{Silagem de milho versus cana-de-açúcar - Consumo e produção de leite}

A silagem de milho e a cana-de-açúcar representam duas das principais alternativas para a alimentação de bovinos leiteiros durante o período de entressafra. Para cana-de-açúcar, a produtividade elevada, custo baixo por unidade de MS e manutenção do valor nutritivo por períodos prolongados são argumentos freqüentemente utilizados para justificar seu emprego na alimentação de bovinos leiteiros. Assim, sua utilização como alternativa para substituição de forragens mais tradicionais (silagem de milho) tem sido avaliada 
(Boin et al., 1983a; Boin et al., 1983b, Correa et al., 2000; Magalhães et al., 2000; Mendonça et al., 2001).

Boin et al. (1983a) utilizaram vacas mestiças em início de lactação para comparar silagem de milho ou cana-de-açúcar como volumosos exclusivos e com dois níveis de suplementação ( $1 \mathrm{~kg}$ de concentrado para cada $2,5 \mathrm{~kg}$ de leite acima de 5 ou $8 \mathrm{~kg} / \mathrm{d}$ ). Apesar do consumo de MS maior para as vacas recebendo cana-de-açúcar, as produções de leite não foram afetadas pelo tratamentos e oscilaram entre 13,4 a $13,8 \mathrm{~kg} / \mathrm{d}$ nas dietas com silagem de milho e 14,6 e 14,7 kg/d nas dietas com cana-de-açúcar. Em um segundo trabalho, Boin et al. (1983b) também compararam a silagem de milho e cana-de açúcar como volumosos para vacas em lactação, com a suplementação de $1 \mathrm{~kg}$ concentrado para cada $2,5 \mathrm{~kg}$ de leite produzido acima de $8 \mathrm{~kg} / \mathrm{d}$. Neste trabalho também não foram observadas diferenças entre tratamentos quanto a produção de leite que oscilou entre 13,0 a 15,2 kg/d nas dietas com silagem de milho e 15,7 a 17,0 kg/dia nas dietas com cana-de-açúcar. Portanto, com dietas ajustadas corretamente para atender exigências diárias de mantença e produção, a cana-de-açúcar mostrou-se equivalente a silagem milho para vacas produzindo até $17,0 \mathrm{~kg} / \mathrm{dia}$.

Recentemente, a substituição parcial ou total da silagem milho por canade-açúcar em dietas de vacas em lactação produzido mais de $20 \mathrm{~kg}$ de leite/d vem sendo avaliada e, em geral, o consumo de MS e produção diminuíram quando a cana-de-açúcar substituiu total ou parcialmente a silagem milho (Correa et al., 2000; Magalhães et al., 2002 Mendonça et al., 2001). A redução no consumo observada nas dietas que incluem cana-de-açúcar pode ser explicada pela digestibilidade menor da FDN, que contribui para aumentar 0 enchimento ruminal e limitar a ingestão.

Mendonça et al. (2002) avaliaram os efeitos da cana-de-açúcar no consumo de MS e digestibilidade aparente de nutrientes de vacas em lactação. Três dietas foram balanceadas com relação V:C de 60:40, utilizando a silagem de milho, a cana-de-açúcar adicionada de 0,35\% de úreia:sulfato de amônio 9:1 
ou a cana-de-açúcar adicionada de 1\% de uréia:sulfato de amônio 9:1 e, na quarta dieta, foi utilizada a relação $\mathrm{V}: C$ de 50:50 com a cana-de-açúcar adicionada de 1\% uréia:sulfato de amônio 9:1. Nas duas relações $V: C$, a utilização de cana-de-açúcar reduziu o consumo de MS e a digestibilidade da FDN. Ao avaliarem a digestibilidade "in vitro" de volumosos exclusivos ou combinados, Campos et al. (2001) também verificaram que a digestibilidade da FDN cana-de-açúcar foi inferior àda silagem de milho (31,8 vs. 39,1; $\mathrm{P}<0,05)$.

$O$ efeito de repleção ruminal da FDN da cana-de-açúcar e cama de frango foi avaliado por Pereira et al. (2000). Neste trabalho foi verificado que taxa baixa de degradação da FDN potencialmente degradável e a concentração elevada de FDN não degradável na cana-de-açúcar foram os principais fatores que explicaram o efeito de repleção ruminal elevado e disponibilidade energética baixa da cana-de-açúcar no trato gastrointestinal.

A digestibilidade da FDN cana-de-açúcar pode ser aumentada através de tratamentos químicos que rompem as ligações entre a lignina e polissacarídeos da parede celular. Durante a hidrólise com álcali $\left(\mathrm{NaOH}, \mathrm{NH}_{4} \mathrm{OH}\right)$, as ligações do tipo éster entre a lignina e polissacarídeos da parede celular secundária são rompidas, tornando os carboidratos disponíveis para degradação por microrganismos ruminais, o que aumenta taxa e extensão de degradação da celulose e hemicelulose (Chesson, 1993; Klopfenstein \& Owen, 1981). Por outro lado, os carboidratos da parede celular primária não são disponibilizados porque formam complexos com a lignina que são resistentes à ação de álcali (Chesson, 1993). Além do rompimento das ligações entre a lignina e polissacarídeos da parede celular, parte da hemicelulose é também solubilizada mas as porcentagens de celulose, lignina e FDA são pouco alteradas (Berger et al., 1979).

Vários trabalhos foram conduzidos no Brasil por Ezequiel et al. (2001a,b,c) para avaliar os efeitos do tratamento com $\mathrm{NaOH}$ sobre a composição química e degradabilidade ruminal da cana-de-açúcar. Nestes trabalhos, a cana-de-açúcar "in natura" foi tratada com solução de $\mathrm{NaOH} 50 \%$ 
aplicada na proporção de $1,5 \%(p / v)$ e os principais efeitos observados foram aumento nas porcentagens de FDNpd (52,6\%) e carboidratos solúveis $(26 \%)$ e redução nas porcentagens de hemicelulose e FDN (18,8 e 2,3\%, respectivamente).

Os efeitos do tratamento da cana-de-açúcar com $\mathrm{NaOH}$ sobre o consumo de MS e digestibilidade e nutrientes foram avaliados ultilizando 15 novilhos de 18 meses e pesando $220 \mathrm{~kg}$ (Alves et al., 2001). A cana-de-açúcar foi fornecida como volumoso exclusivo nas formas "in natura" ou tratada com solução de $\mathrm{NaOH} 50 \%$, nas doses de 2 e 4\% (p/v). Para a cana-de-açúcar "in natura" ou tratada com $2 \%$ da solução de $\mathrm{NaOH}$ as porcentagens de FDN foram semelhantes porém, no nível de $4 \%$ de solução de $\mathrm{NaOH}$ houve redução de cinco unidades percentuais na porcentagem de FDN. O consumo de MS não diferiu entre os tratamentos mas as digestibilidades da MS, FDN e FDA foram maiores para os tratamentos com cana-de-açúcar tratada.

\subsection{Subprodutos como fontes de fibra não forragem (FFNF)}

Subprodutos representam fontes valiosas de proteína, energia e fibra para indústria de produção animal (NRC, 1989). Tradicionalmente, os subprodutos tem sido utilizados como suplementos energéticos e, ou, protéicos, embora o valor destes alimentos como FFNF venha sendo pesquisado recentemente (Allen \& Grant, 2000; Clark \& Armentano, 1993, Clark \& Armentano, 1997; Cunningham et al., 1993; Depies \& Armentano, 1995; Mooney \& Allen, 1995; Mowrey at al., 1999; Pereira et al., 1999; Sarwar et al., 1992; Slater et al., 2000; Swain \& Armentano, 1994; Wagner et al., 1993; Weidner \& Grant, 1994a, Weidner \& Grant, 1994b, Younker et al, 1998; Zhu et al., 1997) e revisado (Allen, 1997; Armentano \& Pereira, 1997; Firkins, 1997; Grant, 1997; Mertens, 1997). O uso de subprodutos para atencer exigências de 
fibra representa uma opção importante para rações cujo balanceamento pode ser limitado pela quantidade ou qualidade das forragens disponíveis.

As FFNF são freqüentemente adicionadas àdieta para substituir parte da FDN de forragem. O NRC(1989) sugere que $75 \%$ da fibra deve ser fornecida a partir de forragens, o que equivale à $21 \%$ FDNF na MS. Quando FFNF são incluídas na dieta, a porcentagem de FDN total pode ser mantida em $28 \%$, mas de FDNF pode ser inferior à de $21 \%$ da MS. A redução da porcentagem de FDNF para teores inferiores à $21 \%$ da MS tem sido avaliada em alguns trabalhos (Clark \& Armentano, 1997; Pereira et al., 1999; Slater et al., 2000).

Slater et al.(2000) avaliaram à inclusão de casca de soja e caroço de algodão na dieta de vaca em lactação e concluíram que os teores de FDNF podia ser reduzidos para 9 a $11 \%$ da MS, entretanto com a casca de soja como única fonte de FFNF, o teor de FDNF não devia ser inferior à $14 \%$ da MS. Clark \& Armentano (1997) reduziram a concentração de FDNF para $12 \%$ da MS quando uma combinação de caroço de algodão, resíduo de destilaria e farelo de trigo substituíram parte da FDN de silagem de alfafa. Recentemente, Pereira et al. (1999) estudaram o efeito de longo prazo (112 dias) da substituição de FDNF por uma mistura de FFNF (farelo de glúten de milho, farelo de trigo e resíduo de cervejaria). Eles concluíram que as vacas recebendo porcentagem baixa de FDNF $(12,8 \%)$ e porcentagem alta de FDN total $(33,4 \%)$ foram menos susceptíveis à acidose ruminal do que vacas recebendo porcentagens baixas de FDNF e FDN total.

Os resultados da inclusão de FFNF sobre o consumo de MS têm sido variáveis. Clark \& Armentano (1997) observaram que o consumo de MS aumentou quando quantidades adicionais de fibra a partir de caroço de algodão, resíduo de destilaria e farelo de trigo foram incluídas em uma dieta com $12 \%$ de FDNF. Clark \& Armentano (1993) também verificaram que o consumo de MS foi maior para dietas com 13\% FDNF e 6\% de FDN de caroço de algodão ou resíduo de destilaria, quando comparadas à dieta com porcentagem alta de FDN de alfafa. Devido ao tamanho menor das partículas 
de FFNF, o aumento observado no consumo pode estar relacionado à redução do enchimento ("fill") ruminal, tradicionalmente associado às dietas com alta porcentagem de forragem. Nestes trabalhos (Clark \& Armentano, 1993; Clark \& Armentano, 1997) os delineamentos utilizados foram de quadrado latino $4 \times 4 \mathrm{e}$ os períodos experimentais de 21 dias, entretanto não está claro se a resposta no consumo seria a mesma em trabahos de longa duração. Em dois trabalhos recentes, demonstrou-se que os resultados foram consistentes entre trabalhos de curta e longa duração (Pereira et al., 1999; Slater et al., 2000).

Por outro lado, a substituição FDNF por FDN de FFNF tem afetado negativamente o consumo de MS alguns trabalhos. Harmison et al. (1997) observaram redução linear no consumo de MS quando a porcentagem de FDNF das dietas diminuia (21, 16 e 11\%) e era substituída por FDN de casca de soja. As dietas foram balanceadas com $35 \%$ de FDN total e o decréscimo maior no consumo ocorreu quando a porcentagem de FDNF foi reduzida de 16 para $11 \%$ da MS.

Cunningham et al. (1993) também notaram redução linear no consumo de MS quando 25 e $50 \%$ da MS da silagem de milho foi substituída por FDN de casca de soja e a porcentagem de FDNF era reduzida de 25,2 para $14,2 \%$ da MS. Os autores concluíram que a redução de consumo podia ser atribuída ao tamanho menor de partícula da casca de soja, quando comparada àsilagem de milho.

Weidner \& Grant (1994b) substituíram uma mistura de forragens (silagem de alfafa e milho) por casca de soja. Quando a casca de soja substituiu $25 \%$ da MS da mistura de forragens e um feno picado grosseiro foi também incluído na dieta, o consumo de MS aumentou quando comparado à dieta com casca da soja, porém sem a inclusão de eno (Weidner \& Grant, 1994b). Atividade de mastigação foi também menor para a dieta com casca de soja e sem feno picado. Neste caso, o aumento no tempo de mastigação provavelmente elevou o $\mathrm{pH}$ do fluído ruminal, reduzindo o efeito associativo negativo da porcentagem elevada de FFNF. Além disso, a inclusão casca de soja na dieta alterou 
também a consistência do "mat" em outro estudo conduzido pelos mesmos autores (Weidner \& Grant, 1994a). Os efeitos da substituição de FDNF por FDN de casca de soja sobre a atividade de mastigação e consitência do "mat" ruminal (Weidner \& Grant, 1994a; Weidner \& Grant, 1994b) também explicam a redução no consumo de MS observada quando casca de soja foi fornecida em outros trabalhos (Cunningham et al. 1993; Harmison et al., 1997).

Em contraste com estes resultados, o consumo de MS não diminuiu quando Sawar et al. (1992) substituíram o feno de alfafa e a silagem de milho por casca de soja em dietas com 22 e 18\% de FDNF. A diferença entre os resultados de consumo destes trabalhos pode ser atribuída ao percentual mais elevado de FDNF usado por Sawar et al. (1992) quando comparado aos utilizados por Cunningham et al. (1993) e Harmison et al. (1997).

Em alguns estudos o consumo de MS não foi afetado pela substituição FDNF por FFNF. No trabalho de Swain \& Armentano (1994) o consumo de MS não diferiu quando vacas em lactação receberam dietas de 14\% de FDNF e contendo uma das seguintes FFNF: farelo proteinoso de milho, casca de aveia, resíduo de cervejaria desidratado, polpa de beterraba ou broto de cevada maltada. Depies \& Armentano (1995) também não observaram alterações no consumo de MS quando a FDN de sabugo de milho ou farelo de trigo foram utilizadas para substituir a FDN de silagem de alfafa em dietas com 14,7\% de FDNF. Em sua revisão sobre a utilização de FFNF, Firkins (1997) sugere que para alcançar consumo máximo de MS, dietas de vacas em lactação que icluem FFNF devem ser balanceadas com 25 a 35\% de FDN total, 14 a $16 \%$ de FDNF e 33 e $40 \%$ de carboidratos não fibrosos (CNF).

\subsection{Efeitos de FFNF sobre a digestibilidade}

A FDN de vários subprodutos é potencialmente mais digestível no rúmen do que a FDNF (Firkins, 1997). Como exemplo, a digestibilidade ruminal da 
FDN da polpa de beterraba e resíduo de destilaria desidratado tem sido estimada em 68,9 e 71,6\%, respectivamente, enquanto a FDN da alfafa e silagem de milho tem digestibilidade ruminal estimada de 30,9 a 62,5\% e 23,8 a $58,4 \%$, respectivamente (Firkins, 1997). Assim, existe potencial para aumentar a digestibilidade ruminal e de trato total da FDN quando FFNF substituem forragens em dietas de vacas em lactação. Por outro lado, a taxa de digestão da FDN de FFNF no rúmen é semelhante ou inferior a de forragens e, além disso, estas fontes de fibra têm tamanho menor de partículas e gravidade específica maior (Firkins, 1997; Bhatti e Firkins, 1995). A combinação destes fatores (taxa de digestão, tamanho de partícula e gravidade específica) contribui para taxa de passagem mais rápida dos subprodutos do que das forragens. Como digestão e passagem são processos que competem entre si, as FFNF devem ser retidas no rúmen para aumentar a digestibilidade ruminal de FDN. Devido à taxa de passagem mais rápida pelo rúmen de FFNF a excreção de FDN potencialmente digestível freqüentemente aumenta quando FFNF são utilizadas para substituir FDNF (Firkins, 1997). Mais estudos são necessários para medir a taxa de passagem de FFNF sob diferentes condições de alimentação.

No rúmen, as interações que ocorrem entre FFNF e forragens podem aumentar a digestibilidade da FDN. Weidner \& Grant (1994a) substituíram 40\% de uma mistura de silagens de alfafa e milho por casca de soja ( $25 \%$ da MS) em dietas de vacas em lactação, com ou sem a inclusão de feno de alfafa picado grosseiro. A inclusão de casca de soja e feno aumentou a consistência do "mat", elevou o pH ruminal e aumentou o tempo de ruminação. Sem a inclusão do feno, a casca de soja não apresentou a mesma efetividade. $O$ aumento na consistência do "mat" foi provavelmente determinado por alterações na distribuição de partículas por tamanhos da digesta ruminal e taxa de passagem $(0,049 / \mathrm{h}$ e $0,057 / \mathrm{h}$ para casca de soja nas dietas com e sem a adição de feno, respectivamente) quando a casca de soja foi fornecida em combinação com feno. Em trabalho semelhante de Allen \& Grant (2000), a FDN 
do farelo proteinoso de milho substituiu 10,7 unidades percentuais de FDN de silagem de alfafa em dietas com ou sem feno de picado grosseira. A substituição da FDNF por FDN de farelo proteinoso úmido de milho e a inclusão de feno aumentaram a consistência do "mat" ruminal e os tempos e mastigação e ruminação, e diminuiu a taxa de passagem do farelo proteinoso quando comparada àsubstituição sem feno.

Embora a digestibilidade da FDN não tenha sido avaliada nestes estudos, dietas semelhantes foram fornecidas em um trabalho de Weidner \& Grant (1994b) no qual a casca de soja substituiram 15 e $25 \%$ da MS de forragem (silagens de alfafa e milho), com ou sem a inclusão de feno picado grosseiro. A inclusão cascas de soja (15\% da MS) e feno aumentaram a digestibilidade da FDN no trato total (61,5 vs. $48,6 \%$ para casca de soja com e sem feno, respectivamente). $O$ aumento na digestibilidade da FDN foi decorrente do aumento na consistência do "mat" rumimal e redução da taxa de passagem da casca de soja, observado previamente por Weidner \& Grant (1994a) quando a casca de soja foi fornecida juntamente com feno picado. Quando a casca de soja foi incluída na porcentagem mais elevada (25\% da MS), a digestibilidade aparente da FDN no trato total foi maior para dieta sem a inclusão de feno picado grosseiramente $(60,5 \%$ vs. 58,0$)$ (Weidner \& Grant, 1994b).

Estes resultados podem ser atribuidos à substituição das silagens de milho e alfafa por feno alfafa, que apresentava concentração maior de FDN e possivelmente era menos digestível do que as silagens (Weidner \& Grant, 1994b). Embora a digestibilidade ruminal de FDN não tenha sido avaliada neste estudo, pode ter ocorrido digestão compesatória de FDN no intestino grosso, o que contribuia para aumentar a digestibilidade de FDN no trato total quando a casca de soja passa pelo rúmen ante de ser completamente digerida.

A substituição de FDNF por FDN de FFNF nem sempre afeta positivamente a digestibilidade de FDN, apesar da proporção maior de FDN potencialmente digestível (FDNpd) de FFNF. Sawar et al. (1992) substituíram o 
feno de alfafa e silagem de milho por casca de soja (4,6 e 9,1\% da MS), porém a digestibilidade aparente de FDN no trato total diferiu entre os tratamentos. Os autores especularam que $\mathrm{pH}$ baixo do fluído ruminal $(<6,0)$ pode ter reduzido a proporção de FDNpd no rúmen. Além disso, o consumo elevado e taxa de passagem podem ter limitado a digestão compensatória de FDN no intestino. Cunningham et al. (1993) substituiram 23 e $45 \%$ da MS de forragens por casca de soja, mas não encontraram diferenças nas digestibilidades ruminal e de trato total da FDN, embora os valores numéricos tenham sido maiores para dietas com cascas de soja.

Nenhuma diferença foi observada também na digestibilidade aparente da FDN no trato total quando parte da forragem foi substituida farelo de trigo (Wagner et al., 1993; Zhu et al., 1996), resíduos de cervejaria desidratado (Younker et al., 1998), farelo proteinoso de milho (Zhu et al., 1996), ou uma mistura de farelo de trigo e farelo proteinoso de milho (Zhu et al., 1996). Em sua revisão, Firkins (1997) utilizou uma série de regressões para concluir que a porcentagem de FFNF na dieta tem aproximadamente $2 / 3$ da resposta positiva sobre a digestibilidade de FDN no trato total quando comparada à FDNF. $O$ aumento na excreção de FDN digestível, quando FFNF substituem forragens, pode ser atribuído ao efeito associativo negativo nas dietas com baixa porcentagem de FDNF (menor pH do fluído ruminal deprimindo à digestão de fibra) ou taxa de passagem mais rápida de FFNF quando comparada à forragens.

\subsection{Efetividade de FFNF}

A efetividade da fibra de FFNF tem sido avaliada através dos métodos previamente descritos. A maioria dos trabalhos que avaliaram a efetividade de FFNF foram de curta duração, utilizando delineamento quadrado latino e com duas ou quatro semanas por período experimental. Baseado nos resultados 
destes trabalhos, em média, a FDN de FFNF apresentou, aproximadamente, metade da efetividade da FDN de silagem de alfafa para manter a porcentagem de gordura no leite (Swain \& Armentano, 1994) e menos da metade da efetividade da FDN de forragem para estimular a atividade de mastigação (Firkins, 1995).

Recentemente, Pereira et al. (1999) avaliaram os efeitos de longo prazo (112 d) do fornecimento de uma combinação de FFNF em substituição a FDN de alfafa e concluíram que a FDN de subprodutos apresentou apenas $27 \%$ da efetividade da FDN de alfafa para manter a porcentagem de gordura no leite. Entretando, a efetividade da FDN das FFNF varia consideravelmente entre trabalhos. Swain \& Armentano (1994) compararam, em dois experimentos, a efetividade da FDN do farelo proteinoso de milho, casca de aveia e resíduo de cervejaria desidratado à efetividade da FDN de silagem de alfafa. A efetividade da fibra baseada na habilidade para manter a porcentagem de gordura no leite diferiu entre experimentos (farelo proteinoso de milho $=0,71$ e 0,40 ; cascas de aveia $=0,61$ e 0,71 e resíduo de cervejaria desidratado $=0,22$ e 0,46 para os experimentos 1 e 2 repectivamente). Utilizando as respostas de atividade de mastigação correspodentes aos dados de porcentagem de gordura no leite do trabalho de Swain \& Armentano (1994), Mertens (1997) calculou, baseado na atividade de mastigação, a efetividade da FDN destas FFNF, que também diferiram entre os experimentos (farelo proteinoso de milho $=0,63$ e 0,04 ; cascas de aveia $=0,17$ e 0,22 e resíduo de cervejaria desidratado $=0,80$ e 0,32 para os experimentos 1 e 2, repectivamente). Adicionalmente, Mertens (1997) também calculou FDNfe baseado no tamanho de partícula (porcentagem de amostra retida em peneira $\geq 1,18 \mathrm{~mm}$ ) e concentração de FDN, também notando diferença entre experimentos (farelo proteinoso de milho $=0,09$ e 0,04; cascas de aveia $=0,04$ e 0,21 e resíduo de cervejaria desidratado $=0,24$ e 0,24 para os experimentos 1 e 2 , repectivamente). Mais pesquisas são necessárias para explicar à variação considerável entre estudos e para otimizar o uso de FFNF como alternativa de substituição de forragens e sem desafiar a 
fermentação ruminal. Além disso, os efeitos de longo prazo do fornecimento de FFNF precisam ser determinados, principalmente para predizer os valores corretos de efetividade para cada alimento e em uma situação específica de alimentação.

\subsection{Resposta na produção de leite quando FFNF substituem forragens}

As respostas na produção de leite devem ser consideradas como um fator importante na avaliação de FFNF. Na maioria dos trabalhos foi demonstrado que a substituição de FDNF por FDN de FDNF resultou em produção de leite semelhante à obtida quando a FDNF foi incluída em dietas balanceada com teores equivalentes de FDN total (Clark \& Armentano, 1993; Depies \& Armentano, 1995; Harmison et al. 1997; Mowrey et al., 1999; Pereira et al., 1999; Swain \& Armentano, 1994; Wagner et al., 1993). No trabalho de Clark \& Armentano (1997), a produção de leite aumentou quando a FDN de alfafa foi substituida pela FDN de uma combinação de FFNF (caroço de algodão, resíduo de destilaria desidratados e farelo de trigo). Quando o caroço de algodão substituiu parcialmente a FDN de silagem de alfafa, Mooney \& Allen (1997) também notaram que a produção de leite aumentou (35,5 vs. 33,7 kg/d) em resposta ao aumento no consumo de MS observado nas vacas receberam dietas com caroço de algodão. $O$ aumento na densidade energética das dietas que incluiam caroço de algodão também favoreceu o aumento na produção de leite, segundo os autores.

\subsection{Efeitos de longo prazo do uso de FFNF}

O uso de FFNF em experimentos de longa duração tem demonstrado resultados variáveis sobre a produção de leite. Slater et al. (2000) observaram diferenças na produção de leite quando FFNF substituíram FDNF e as dietas 
foram fornecidas da décima até a vigésima quinta semana de lactação. As produções de leite mais elevadas foram observadas nas dietas com 9,4\% de FDNF que incluíam $11 \%$ de caroço de algodão e $23,9 \%$ cascas de soja. Neste caso, a resposta foi atribuída ao aumento no consumo de MS. Em trabalho de 16 semanas, Pereira et al. (1999) notaram um aumento na produção de leite quando dietas com porcentagem baixa de FDNF e alta FDN total (inclusão de FFNF substituindo FDNF) foram comparadas à dietas com porcentagens baixas de FDNF e FDN total. A substituição das silagens de milho e alfafa por casca de soja, com a inclusão de feno longo nas dietas, também aumentou a produção de leite em um experimento de 12 semanas (Weidner \& Grant, 1994b). Após revisar vários experimentos nos quais a casca de soja substituiu a FDNF, Grant (1997) concluiu que subprodutos podiam ser fornecidos com sucesso a partir de 28 dias de lactação, porém os poucos dados disponíveis na literatura ainda não permitiam a utilização com segurança para os primeiros 28 dias de lactação (período de transição) porque poucos estudos foram iniciados antes deste período.

Quando substituíram a FDN das silagens de milho e aflfa por casca de soja, Wang et al. (1999) concluíram que 17\% de FDNF não seria suficiente para os primeiros 30 dias de lactação. Neste trabalho, as respostas no consumo de MS e produção de leite dependeram da concentração e forma de processamento da forragem. Diferenças na porcentagem de gordura no leite tem sido detectadas em experimentos conduzidos para atribuir valores de efetividade para fibra de FFNF (Clark \& Armentano, 1993; Clark \& Armentano, 1997; Depies \& Armentano, 1995 e Swain \& Armentano, 1994). A inclusão de FFNF na dieta tem resultado também no aumento da porcentagem ou produção de proteína no leite (Clark \& Armentano, 1993; Clark \& Armentano, 1997; Depies \& Armentano, 1995; Mooney \& Allen, 1997 e Weidner \& Grant, 1994a). 


\section{ANÁLISE COMPARATIVA DA EFETIVIDADE DA FIBRA DE VOLUMOSOS}

\section{Resumo}

Cinco vacas holandesas com cânulas no rúmen e duodeno foram utilizadas em um delineamento quadrado latino $5 \times 5$ para avaliar a efetividade da fibra da cana-de-açúcar "in natura" (cana) ou tratada com $\mathrm{NaOH}$ (canaNaOH). Duas dietas, uma com baixa e outra alta porcentagem de FDN oriunda de forragem (14 e $22 \%$ de FDN na MS a partir de silagem de milho, respectivamente), foram comparadas com dietas balanceadas para conter $14 \%$ de FDN de silagem de milho e $8 \%$ de FDN proveniente cana, canaNaOH ou feno de alfafa (f.alfafa), na base da MS. O consumo de matéria seca, produção e composição do leite não foram afetados pela concentração ou fonte de FDN das dietas. $\mathrm{O} \mathrm{pH}$ ruminal, proporções molares de $A G V$ e relação acetato:propionato foram afetados pela concentração e fonte de FDN das dietas. O tempo de mastigação ( $\mathrm{min} / \mathrm{d}$ e $\mathrm{min} / \mathrm{kg}$ de MS) foi menor na dieta com $14 \%$ de FDN, porém não diferiu para as dietas com $22 \%$ de FDN de forragem. A partir dos resultados de teor de gordura no leite e comportamento ingestivo foi possível concluir que as forragens avaliadas apresentam efetividades da fibra equivalentes. 


\section{Summary}

Five ruminally cannulated Holstein cows were used in a $5 \times 5$ Latin square design to evaluate fiber effectiveness of sugarcane (SC) and sodium hydroxide treated sugarcane (SHSC). Low and high forage diets (14 and $22 \%$ of dietary DM from corn silage NDF, respectively) were compared with diets formulated to contain $14 \%$ of DM from corn silage NDF plus $8 \%$ of DM from SC NDF or SHSC NDF or alfalfa hay NDF (AF). Dry matter intake, milk yield and composition did not differ across diets. Ruminal pH, VFA and acetate:propionate were affected by level and source of NDF. Chewing time (min./d and min./kg of DMI) was lower for low forage diet but, did not differ between high forage, SC, SHSC and AF diets. The results suggest that SC, SHSC and AF were as effective as corn silage for maintaining milk fat test and stimulating chewing.

\subsection{INTRODUÇÃO}

A fibra é componente essencial da dieta de vacas em lactação, sendo necessária para obtenção de consumo máximo de MS e energia, para estimular a atividade de mastigação e secreção de saliva e manter porcentagem de gordura no leite. Portanto, dietas de vacas em lactação devem conter uma porcentagem mínima de fibra para manter a função ruminal normal e evitar a ocorrência de distúrbios metabólicos. Por outro lado, a fibra representa a fração de carboidratos dos alimentos de digestão lenta e variável e, quando incluida acima de determinados limites, definidos principalmente pelo potencial de produção do animal, pode limitar o consumo de MS e desempenho.

Os limites de fibra em dietas bovinos leiteiros são definidos não apenas por concentrações mínimas e máximas, mas também por atributos físicos, químicos e biológicos dos alimentos usados nas formulações de dietas. Desta 
forma, novos conceitos para balanceamento de dieta vem sendo elaborados e incorporados a formulação de dietas de bovinos leiteiros. O NRC (1989) sugere que dietas de vacas em lactação devem conter, no mínimo, 25 a $28 \%$ de FDN total com $75 \%$ deste total sendo suprido por forragens. Além disso, o NRC (1989) sugere também que pelo um terço da MS total de dieta deveria ser fornecido como feno de fibra longa ou seus equilaventes, reconhecendo assim a importância de atributos físicos de forragens para o balanceamento de dietas. Em sua edição mais recente, o NRC (2001) sugere que, quando as forragens possuem tamanho de partículas adequado, dietas de vacas em lactação devem ser balanceadas com, no mínimo, 25\% de FDN total e 19\% de FDNF.

Dois novos conceitos para 0 balanceamento de fibra foram desenvolvidos visando considerar não apenas a concentração da FDN nos alimentos mas também atributos físicos e biológicos que afetem a atividade de mastigação e teor de gordura no leite (Mertens, 1997). O conceito de fibra fisicamente efetiva (FDNfe) visa incorporar na definição de exigências de fibra atributos físicos (principalmente tamanho de partículas) que estimulem a atividade de mastigação e estabeleçam uma estratificação bifásica do conteúdo ruminal (Mertens, 1997). Por outro lado, a fibra efetiva (FDNe) está relacionada à habilidade de um alimento qualquer para substituir uma forragem e ainda assim manter a porcentagem de gordura no leite (Mertens, 1997). Assim, variações no tamanho de partículas ou outros atributos dos alimentos (digestibilidade da fibra) que contribuam para alterar a atividade de mastigaçao e, ou, teor de gordura no leite podem afetar os valores de FDNef e FDNe.

A importância do tamanho de partículas de forragens para efetividade da fibra vem sendo avaliada porém, nem sempre com resultados consistentes sobre a atividade de mastigação e ou teor de gordura no leite (Bal et al. 2000; Clark \& Armentano, 1999; De Boever et al., 1993a; De Boever et al., 1993b; Mooney \& Allen, 1997; Schawb et al., 2002; Soita et al. 2000). Na maioria dos trabalhos, não houve efeito significativo do tamanho de partícula sobre o teor de gordura no leite (Bal et al. 2000; Clark \& Armentano, 1999; Mooney \& Allen, 
1997; Schawb et al., 2002; Soita et al. 2000). Em três trabalhos, houve efeito significativo do tamanho de partícula sobre a atividade de mastigação (De Boever et al., 1993b; Mooney \& Allen, 1997; Soita et al. 2000), porém nos demais a atividade mastigação não foi afetada (Bal et al. 2000; Clark \& Armentano, 1999; De Boever et al., 1993a; Schawb et al., 2002).

Além do tamanho da partícula, outros fatores relacionados as forragens podem afetar a atividade de mastigação. Variações na taxa de digestão, extensão de digestão e passagem da fibra pelo rúmen alteram o valor de enchimento ("fill") das dietas e podem alterar a atividade de mastigação. Dado e Allen (1995) verificaram que o aumento do valor de enchimento das dietas, simulado através da inclusão de volumes inertes no rúmen, aumentava o tempo de mastigação e o número de contrações reticulares durante a ruminação, comprovando que variações na digestão de fibra no rúmen alteravam a atividade de mastigação. A importância da composição e digestibilidade da FDN da forragem para efetividade da fibra foi detectada em alguns estudos (Beauchemin, 1991, De Boever et al., 1993a) porém, em outras oportunidades não foram encontradas respostas significativas para variações na composição e digestibilidade da fibra (De Boever et al, 1993b; Oba \& Allen, 2000; Poore et al., 1993).

A silagem de milho e cana-de-açúcar diferem em concentração e digestibilidade da FDN. Por apresentar menor lignificação da parede celular, a digestibilidade da FDN da silagem de milho é mais elevada do que da cana-deaçúcar, conforme foi evidenciado por Campos et al. (2001) e Mendonça et al. (2002a). Para estas forragens, a importância da concentração e composição da FDN sobre a atividade de mastigação não vem sendo avaliada com freqüencia.

A atividade de mastigação de vacas em lactação recebendo como forragens exclusivas a silagem de milho ou cana-de-açúcar foi avaliada por Mendonça et al. (2002b). Neste experimento, as vacas receberam dietas com 0 ou $50 \%$ de volumosos e 34 a $28 \%$ de FDN total. Os tempos de ingestão e ruminação não diferiram entre tratamentos, porém houve aumento no tempo de 
mastigação para dieta com silagem de milho. Os autores não calcularam os tempos de ruminação ou mastigação por unidade de MS ou FDN consumidas, porém o consumo de MS foi menor nas dietas com cana-de-açúcar (Mendonça et al., 2002a), o que poderia afetar os resultados de comportamento ingestivo, caso fossem expressos em min/kg de MS ou min/kg de FDN. A partir dos resultados apresentados nos dois trabalhos (Mendonça et al., 2002a; Mendonça et al., 2002b) foi possível calcular os tempos de ruminação (81 vs. $101 \mathrm{~min} / \mathrm{kg}$ de FDN) e mastigação (130 vs. $157 \mathrm{~min} / \mathrm{kg}$ de FDN) para dietas com $60 \%$ de silagem de milho ou cana-de-açúcar, indicando que as atividade ruminação ou mastigação aumentaram quando foram expressas por unidade de FDN. A atividade de mastigação de vacas recebendo dietas com 19-20\% de FDNF a partir de silagens de milho com duas texturas nos grãos ("dent" ou "flint") ou cana-de-açúcar foi avaliada por Correa et al. (2000) que não observaram diferenças na atividade de mastigação ( $\mathrm{min} / \mathrm{d}$ ou $\mathrm{min} / \mathrm{kg}$ de MS) quando as silagens de milho foram comparadas àcana-de-açúcar.

Além do efeito sobre atividade de mastigação, a digestibilidade menor da FDN da cana-de-açúcar também limita o consumo de MS e produção de leite. A redução de consumo observada em dietas com de cana-de-açúcar é explicada pelo efeito de repleção da FDN, ocasionado pela taxa de degradação baixa da FDNpd e concentração elevada de FDN indigestível (Pereira et al., 2000). Na maioria dos trabalhos conduzidos recentemente, a substituição parcial ou total da silagem de milho por cana-de-açúcar reduziu o consumo de MS e produção de leite (Correa et al., 2000; Magalhães et al., 2002; Mendonça et al., 2001).

A restrição de consumo imposta pelo efeito de repleção da FDN da canade-açúcar pode ser diminuida pelo aumento da digestibilidade da fibra empregando-se tratamentos químicos. O tratamento de volumosos com álcalis rompe as ligações entre a lignina e polissacarídeos da parede celular secundária, tornando-os disponíveis para degradação por microrganismo ruminais (Chesson, 1993). Além disso, a composição da parede celular é também alterada pois a maioria da hemicelulose é solubilizada durante o 
tratamento (Berger et al., 1979). O impacto do tratamento da cana-de-açúcar com álcalis sobre composição e digestibilidade de nutrientes vem sendo avaliado (Alves et al., 2001; Ezequiel et al. 2001a; Ezequiel et al. 2001b; Ezequiel et al. 2001c) entretanto, não existem estudos comparando a efetividade da fibra da cana-de-açúcar "in natura" ou tratada com álcalis.

Este trabalho teve por objetivo avaliar a efetividade fibra da cana-deaçúcar "in natura" ou tratada com $\mathrm{NaOH}$, comparadas à silagem de milho como volumoso referência, na dieta de vacas em lactação. Como o feno ou silagem de alfafa são freqüentemente utilizados como referência na avaliação da efetividade da FDN de volumosos e subprodutos, um tratamento adicional, incluindo feno de alfafa, foi também utilizado na comparação com os demais volumosos (silagem de milho ou cana-de-açúcar).

\subsection{MATERIAL E MÉTODOS}

\subsubsection{Animais, tratamentos e delineamento experimental}

O trabalho foi desenvolvido no galpão para ensaios metabólicos do Departamento Zootecnia da Escola Superior de Agricultura "Luiz de Queiroz", em Piracicaba - SP, entre os meses de setembro de 1999 e janeiro de 2000. Foram utilizadas 5 vacas da raça holandesa em lactação, com cânulas no rúmen e duodeno e distribuídas em delineamento quadrado latino $5 \times 5$. As vacas foram alojadas em baias individuais equipadas com comedouro $\mathrm{e}$ bebedouro e, no início do experimento, estavam em período intermediário de lactação. As vacas receberam injeções de $500 \mathrm{mg}$ de somatropina bovina sintética (bST) a cada 12 dias durante o experimento, sendo a primeira dose aplicada uma semana antes do início do primeiro período experimental.

A silagem de milho, a cana-de-açúcar, cana-de-açúcar tratada com $\mathrm{NaOH}$ e feno de alfafa foram utilizados como volumosos no balanceamento das cinco dietas experimentais (Tabela 1). As dietas foram balanceadas para vacas 
em lactação com $612 \mathrm{~kg}$ de PV, produzindo $30 \mathrm{~kg}$ de leite com 3,5\% de gordura, 3,3\% de proteína e 60 dias de lactação. O CPM Dairy (1998) foi utilizado para 0 balanceamento de dietas com teores equivalentes de nutrientes, exceto para concentração e composição da FDN, que foram alteradas de acordo com os tratamentos propostos. Os dados de composição do alimentos contidos na biblioteca do CPM Dairy (1998) foram utilizados no balanceamento das dietas.

A dieta com porcentagem baixa de FDNF (SMB) foi balanceada com $14 \%$ de FDN proveniente de silagem de milho e $22 \%$ de FDN total. A dieta com porcentagem alta de FDNF (SMA) foi balanceada com $22 \%$ de FDNF de silagem de milho e $28 \%$ de FDN total. Estas dietas representavam os controles negativo (SMB) e positivo (SMA) e foram comparadas àtrês dietas que incluiam $14 \%$ de FDN de silagem de milho e $8 \%$ de FDN a proveniente de cana-deaçúcar "in ratura" (cana), cana-de-açúcar tratada como $\mathrm{NaOH}$ (canaNaOH) ou feno de alfafa(f.alfafa), totalizando $22 \%$ de FDNF. Estas dieta também foram balanceada para $28 \%$ de FDN total. A cana-de-açúcar foi tratada durante a colheita com solução comercial de hidróxido de sódio $(\mathrm{NaOH} 50 \% \mathrm{p} / \mathrm{v})$ e aplicada na proporção $2 \%(\mathrm{p} / \mathrm{v})$. A solução de $\mathrm{NaOH}$ foi aplicada com um pulverizador acoplado ao equipamento de colheita (Kit hidrocana) e, após a aplicação, o material permaneceu amontoado ao ar livre por um período de 24 horas para permitir hidrólise da parede celular.

Tabela 1. Composição de ingredientes das dietas

\begin{tabular}{|c|c|c|c|c|c|}
\hline Composição & SMB & cana & $\begin{array}{c}\text { Dietas } \\
\text { canaNaOH }\end{array}$ & f.alfafa & SMA \\
\hline Silagem de milho & 29,4 & 29,6 & $\begin{array}{c}\% \text { da MS } \\
29,2\end{array}$ & 28,8 & 47,3 \\
\hline Milho triturado & 51,6 & 34,6 & 33,9 & 36,9 & 35,1 \\
\hline Farelo de soja & 15,6 & 18,3 & 18,0 & 5,6 & 14,4 \\
\hline Uréia & 0,5 & 0,8 & 0,8 & 0,8 & 0,7 \\
\hline Mineral $^{2}$ & 2,5 & 2,5 & 2,5 & 2,6 & 2,5 \\
\hline Cana-de-açúcar & & 14,2 & & & \\
\hline Cana-de-açúcar + $\mathrm{NaOH}$ & & & 15,7 & & \\
\hline Feno de alfafa & & & & 25,2 & \\
\hline
\end{tabular}

'SMB= Silagem de milho baixa; SMA= Silagem de milho alta. 

2 Suplemento comercial com 22,0\% Ca; 5,5\% P; 10,5\% Cl; 7,0\% Na; 3,5\% Mg; 2,2\% S; 50 ppm Co; 450 ppm Cu; 40 ppm I; 500 ppm Fe; 1500
ppm Mn; 1550 ppm Zn, 20 ppm Se; 90000 UI Vit. A; 75000 UI Vit. D e 1000 UI Vit. E.

\subsubsection{Amostragens e análises laboratoriais}

O experimento teve a duração de 65 dias, divididos em cinco períodos de 13 dias, sendo sete dias de adaptação as rações e seis dias de coletas. As rações foram preparadas duas vezes ao dia após as pesagens e mistura manual de todos os ingredientes; e fornecidas ad libitum em duas refeições as 6:00 e 18:00 horas. As sobras foram pesadas diariamente antes da refeição da manhã para ajustar a quantidade de sobras para $10 \%$ do oferecido. Os ingredientes das rações foram amostrados do oitavo ao décimo dia, e as sobras do nono ao décimo-primeiro dia de cada período. As amostras foram congeladas e, ao final de cada período, reunidas para formar uma amostra composta por animal e ingredientes. Posteriormente, as amostras foram secas em estufa de ventilação forçada a $65^{\circ} \mathrm{C}$ por 48 horas.

As vacas foram ordenhadas diariamente as 5:30 e 17:30, e a produção de leite controlada a cada ordenha. Amostras de leite das ordenhas da manhã e da tarde foram tomadas do oitavo ao décimo-segundo dia de cada período, conservadas com bromopol, refrigeradas, e posteriormente analisadas no Laboratório de Fisiologia da Lactação, do Departamento de Zootecnia da ESALQ/USP, para determinação das concentrações de gordura, proteína, lactose e sólidos totais, utilizando um equipamento de espectrocospia infravermelha. As concentrações e produções de gordura e proteína foram calculadas para cada vaca e período considerando as produções e composições do leite das amostras tomadas diariamente. A concentração média de componentes do leite (gordura e proteína) foi obtida dividindo-se a produção total do componente no período, pela produção total de leite no mesmo período.

As vacas foram monitoradas para determinação da atividade de mastigação durante um período contínuo de 24 horas no oitavo dia de cada 
período de coleta (Weidner \& Grant, 1994b). As atividades de ingestão, ruminação e ócio foram monitoradas a cada cinco minutos. Estas atividades foram acompanhadas por 24 horas, inclusive durante as ordenhas, que foram realizadas sem a retirada das vacas dos alojamentos. O tempo total despendido em cada atividade ( $\mathrm{min} / \mathrm{d}$ ) foi calculado multiplicando-se o número total de observações em cada atividadade por cinco. O tempo mastigação foi calculado através da soma dos tempos de ingestão e ruminação. Os tempos despendidos nestas atividades por $\mathrm{kg}$ de MS e FDN consumidos, foram calculados dividindose o tempo total em cada atividade pelos consumo de MS e FDN. Para os cálculos considerando a FDNF, nas dietas SMB e SMA e tempos de ingestão e ruminação foram calculados dividindo-se o tempo total de cada atividade pelo consumo de FDN de silagem de milho $(\mathrm{kg} / \mathrm{d})$. Para as dietas cana, canaNaOH e f.alfafa, estes tempos foram calculados dividindo-se o tempo total de cada atividade pela soma dos consumos de FDN de silagem de milho e de outras forragens. Os coeficientes de efetividade da fibra e intervalo de confiança para estas estimativas foram obtidos de acordo com a metodologia utilizada por Mooney \& Allen (1997) e, neste caso, também foi considerada a estimativa de atividade basal de mastigação calculada por estes autores (355 min/d).

A consistência do "mat" ruminal foi avaliada 2, 4 e 6 horas após a alimentação da manhã no nono dia dos períodos de coleta (Welch, 1982), Um peso de metal de $500 \mathrm{~g}$ amarrado à um cordão de náilon foi inserido no saco ventral do rúmen, através da cânula e atravessando a camada flutuante da digesta, uma hora antes das medições. Após o período de estabilização da camada flutuante do rúmen, a extremidade externa do cordão de náilon foi fixada à um peso de metal externo de $1500 \mathrm{~g}$, sendo computado o tempo de ascendência ( $\min$ e $\mathrm{s}$ ) do peso de $500 \mathrm{~g}$ até o ponto superior da camada flutuante e o deslocamento vertical $(\mathrm{cm})$ do peso externo. As taxas de ascensão do peso interno $(\mathrm{cm} / \mathrm{s})$ foram calculadas dividindo-se o deslocamento do peso externo $(\mathrm{cm})$ pelo tempo total $(\mathrm{s})$ que o peso interno levava para atingir o ponto superior da camada flutuante de partículas. 
Amostras de fluído ruminal $(+200 \mathrm{~mL})$ de cinco pontos diferentes foram retiradas do rúmen com auxílio de um tubo rígido de metal de parede perfurada. O tubo foi inserido no rúmen através da cânula e acoplado a um dispositivo gerador de vácuo, a partir do décimo e até o décimo-segundo dia de cada período. As amostras foram coletadas imediatamente antes da alimentação da manhã e posteriormente a intervalos de três horas durante décimo dia. A partir do décimo-primeiro dia, os horários de amostragem foram adiantados em uma hora e meia, totalizando 16 horários de coleta. $\mathrm{O} \mathrm{pH}$ do fluído ruminal foi determinado imediatamente após a coleta e, em seguida, alíquotas de $4 \mathrm{~mL}$ do fluído ruminal, em duplicata, foram adicionadas de $1 \mathrm{ml}$ de ácido metafosfórico $25 \%$, congeladas e armazenadas em freezer $\left(-4^{0} \mathrm{C}\right)$. Posteriormente as amostras foram descongeladas, centrifugadas em $12500 \times \mathrm{g}$ a $4^{\circ} \mathrm{C}$ por 15 minutos e o sobrenadante analisado para determinação de AGV (Erwin et al, 1961) utilizando gás cromatógrafo (modelo 5890 Série II, Hewlett Packard).

Amostras de silagem de milho marcadas com cromo (Cr-mordente) foram utilizadas para determinação da taxa de passagem da silagem de milho(Uden et al., 1980). Para determinação das taxas de passagem da cana-de-açúcar "in natura", cana-de-açúcar tratada e feno de alfafa, amostras destes alimentos foram marcadas com cloreto de itérbio $\left(\mathrm{YbCl}_{3} \cdot 6 \mathrm{H}_{2} \mathrm{O}\right)$ de acordo com Bowman et al. (1991). Amostras dos alimentos marcados $\pm 200 \mathrm{~g}$ para silagem e $\pm 100 \mathrm{~g}$ para cana-de-açúcar e feno de alfafa) foram introduzidas no rúmen através da cânula, no décimo dia de cada período. Após a dosagem, o conteúdo ruminal foi misturado manualmente. Antes das dosagens, amostras de fezes foram tomadas para determinação das concentrações de $\mathrm{Cr}$ e $\mathrm{Yb}$, sendo estes valores utilizados para correção das concentrações nos demais horários de coletas ("background"). Em seguida, amostras de fezes $(+200 \mathrm{~g}$ ) foram tomadas às 6; $12 ; 18 ; 25,5 ; 31,5 ; 37,5 ; 43,5 ; 48,0 ; 54,60$ e 72 horas após as dosagens e congeladas para análises posteriores. As amostras de fezes foram secas a $65^{\circ} \mathrm{C}$, durante 48 horas, moídas em moinho tipo Wiley com tela de $1,0 \mathrm{~mm}$ (Wiley Mill; Arthur H. Thomas, Philadelphia, PA) e analisadas para 
determinação de $\mathrm{Cr}$ e $\mathrm{Yb}$ no Laboratório de Instrumentação Nuclear/CENA/USP. As amostras de cada animal e horário de coleta foram analisadas simultaneamente para determinação de $\mathrm{Cr}$ e $\mathrm{Yb}$, utilizando a técnica de fluorescência de raios $X$ com dispersão de energia. Para excitação dos elementos contidos nas amostras foram utilizados os raios $X$ Mo-K $\alpha(17,44$ $\mathrm{KeV}$ ), provenientes de um tubo de raios $X$ com alvo de Mo e filtro de $Z r$, operado a $25 \mathrm{kV}$ e $10 \mathrm{~mA}$. Na detecção dos raios $X$ característicos emitidos pelo $\mathrm{Cr}$ e $\mathrm{Yb}$ foi utilizado um detector semicondutor de $\mathrm{Si}(\mathrm{Li})$, acoplado a um analisador de pulsos multicanal. Nesta técnica, as áreas sob os picos são proporcionais a intensidade do raio $\mathrm{X}$ emitido por um elemento e também proporcional a sua concentração na amostra (Nascimento Filho, 1999). As taxas de passagem foram determinadas pela regressão do logaritmo natural (In) das taxas de contagem (cps) da porção descendente das curvas para cada elemento contra os tempos de coleta (Faichney, 1975).

Para determinação da taxa de passagem de fluídos, uma solução $(1 \mathrm{~L})$ contendo $6 \mathrm{~g}$ de CoEDTA foi introduzida no rúmen através da cânula, antes da alimentação da manhã, no dia 10 de cada período de coleta (Uden et al., 1980). Antes das dosagens, amostras de fezes foram tomadas para determinação da concentração de Co, sendo este valor usado para correção das concentrações de Co nos demais horários de coletas ("background"). Em seguida, amostras de fezes $(\neq 200 \mathrm{~g})$ foram tomadas à $6 ; 12 ; 18 ; 25,5 ; 31,5$; 37,$5 ; 43,5 ; 48,0 ; 54,60$ e 72 horas a após as dosagens e congeladas para análises posteriores. Para o Co, os procedimentos no preparo e análise das amostras de fezes, e cálculo das taxas passagem, foram os mesmos descritos acima para $\mathrm{Cr}$ e $\mathrm{Yb}$.

As digestibilidades das dietas no rúmen e trato total foram estimadas utilizando como marcador FDA indigestível (FDA $i$ ) (Berchielli et al., 2000). Amostras de fezes $( \pm 200 \mathrm{~g})$ e duodeno $( \pm 250 \mathrm{~mL}$ ) foram tomadas, a cada três horas, do décimo ao décimo-segundo dia de cada período. As amostras foram congeladas e, ao final de cada período, compostas por vaca e secas em estufa 
a $65^{\circ} \mathrm{C}$ por 48 horas. Posteriomente, as amostras foram moídas em moinho tipo Wiley com tela de 1,0 mm (Wiley Mill; Arthur H. Thomas, Philadelphia, PA) e armazenadas para análises. Para determinação das concentrações de FDAi, amostras $(0,25 \mathrm{~g})$ de ingredientes das dietas, duodeno e fezes foram incubadas 'in vitro" por 144 horas (Berchielli et al., 2000) e analisadas em seguida para determinação de FDA (Undersander et al., 1993). As digestilidades de MS e $\mathrm{MO}$, no trato total, e FDN e FDNpd, no rúmen e trato total, foram estimadas utilizando as seguintes equações (Schneider \& Flatt, 1975):

Digestibilidade da MS (trato total):

Dig. $=100-100 \times \quad$ Indicador no alimento (\% da MS)

indicador nas fezes (\% da MS)

Digestibilidade da FDN e FDNpd (rúmen):

Dig. $=100-100 \times \quad$ Indicicador no alimento $(\% \mathrm{MS}) \times \%$ no nutriente no duodeno $(\% \mathrm{MS})$

Indicador no duodeno (\% MS) x \% no nutriente no alimento (\% MS)

Digestibilidade da MO, FDN e FDNpd (trato total):

Dig. $=100-100 \times \quad$ Indicador no alimento $(\% \mathrm{MS}) \times \%$ no nutriente nas fezes $(\% \mathrm{MS})$ Indicador nas fezes (\% MS) x \% no nutriente no alimento (\% MS)

As amostras de ingredientes das dietas, duodeno e fezes, previamente seca em estufa a $65^{\circ} \mathrm{C}$, durante 48 horas, foram moídas em moinho tipo Wiley com tela de 1,0 mm (Wiley Mill; Arthur H. Thomas, Philadelphia, PA) e analisadas para determinação de $M S$, PB, MM, EE (AOAC, 1990). As concentrações FDN, FDA e lignina foram determindadas seqüencialmente de acordo com Undersander et al. (1993). Na determinação de FDN foram incluídos o sulfito de sódio e a amilase termoestável (Termamyl 120 L) e na determinação de lignina foi utilizada solução de $\mathrm{H}_{2} \mathrm{SO}_{4} 72 \%$. Para determinação da FDN indigestível (FDNi), amostras de 0,25 g de ingredientes das dietas, 
duodeno e fezes, previamente secas e moídas, foram incubadas "in vitro" 144 horas (Berchielli et al., 2000) e analisadas para determinação de FDN (Undersander et al., 1993). As concentrações de FDNpd de ingredientes das dietas, duodeno e fezes foram calculadas por diferença $\left(\right.$ FDNpd, $(\% \mathrm{MS})=\mathrm{FDN}_{(\%}$ $\left.\mathrm{MS})-\mathrm{FDNi} \mathrm{i}_{(\% \mathrm{MS})}\right)$.

A distribuição de partículas por tamanhos da silagem de milho, cana-deaçúcar "in natura", cana-de-açúcar tratada, feno de alfafa e sobras foi determinada de acordo com Lammers et al. (1996). Aproximadamente $500 \mathrm{~g}$ das forragens ou $700 \mathrm{~g}$ de sobras foram colocadas em separador de partículas modelo Penn State (Penn State Particle Size Separator, University Park, PA) e, em seguida, submetidas à oito sequências de cinco movimentos horizontais. A cada sequência de cinco movimentos, as peneiras eram submetidas a rotação de $90^{\circ}$. Ao final das oito seqüencias, as frações retidas nas peneiras de $19 \mathrm{~mm}$, $8 \mathrm{~mm}$ e abaixo de $8 \mathrm{~mm}$ (fundo) foram transferidas para bandejas, pesadas e usadas calcular as porcentagens de partículas acima de $19 \mathrm{~mm}$ (retidas em peneira de $19 \mathrm{~mm}$ ), entre $819 \mathrm{~mm}$ (retidas na peneira de $8 \mathrm{~mm}$ ) e abaixo de $8 \mathrm{~mm}$. Os demais ingredientes das dietas (milho triturado e farelo de soja), não foram submetidos à separação de partículas e, para estes alimentos, a porcentagem de partículas abaixo de $8 \mathrm{~mm}$ foi considerada como igual a 100\%.

Para o cálculo do tamanho de partícula das rações consumidas (TPRC), as quantidades de ingredientes fornecidas pelas dietas $(\mathrm{kg} / \mathrm{dia})$ foram multiplicadas pelas porcentagens de particulas acima de $19 \mathrm{~mm}$, entre $8-19 \mathrm{~mm}$ e abaixo de $8 \mathrm{~mm}$ de cada ingrediente. Estes valores foram em seguida descontados da quantidade $(\mathrm{kg} / \mathrm{d})$ de particulas acima de $19 \mathrm{~mm}$, entre $8-19 \mathrm{~mm}$ e abaixo de $8 \mathrm{~mm}$ obtidas para as sobras, calculando-se assim, os consumos para cada extrato de tamanho de particula. O consumos foram então transformados em porcentagem de partículas nos diferentes extratos e plotados em um gráfico de distribuição lognormal (Weibull paper). O TPRC foi determinado no ponto interseção entre $50 \%$ da porcentagem cumulativa de partículas,(eixo y) com tamanho de partículas (eixo x). 


\subsubsection{Análise estatística}

O dados foram analisados utilizando o procedimento de modelos mistos (PROC MIXED) do pacote estatístico do SAS (1996) e de acordo com o seguinte modelo:

$$
Y i j k=\mu+V i+P j+T k+e i j k
$$

em que: Yijk, dado referente ao iésimo animal, do jésimo período, do $\mathrm{k}$ ésimo tratamento; $\mu$, média geral observada; $\mathrm{Vi}$, efeito aleatório do i-ésimo animal; $\mathrm{Pj}$, efeito fixo jésimo período; Tk, efeito fixo k-ésimo tratamento; e eijk, erro aleatório associado ao i-ésimo animal, do j-ésimo período do k-ésimo tratamento. Os efeitos de tratamentos foram comparados através dos seguintes contrastes:

SMB vs. FOR: Avaliar a inclusão de $8 \%$ de FDN de três forragens a uma dieta basal com 14\% FDN proveniente de silagem de milho.

SMA vs. FOR: Comparar de $8 \%$ de FDN proveniente silagem de milho à $8 \%$ de FDN de três fontes alternativas de forragem.

cana vs. FA: Comparar $8 \%$ de FDN proveniente de cana-de-açúcar à $8 \%$ de FDN proveniente de feno de alfafa.

cana : Comparar $8 \%$ de FDN proveniente de cana-de-açúcar à $8 \%$ de FDN proveniente de cana-de-açúcar tratada $\mathrm{NaOH}$.

A consistência do "mat" ruminal, $\mathrm{pH}$ do fluído ruminal e AGV foram analisados nos diferentes horários de coleta utilizando a análise de medidas repetidas no tempo (REPEATED), com estrutura de convariância autoregressiva de primeira ordem $[A R(1)]$, utilizando o procedimento de modelos mistos (PROC MIXED) do pacote estatístico do SAS (1996). Para rejeiçao ou aceitação no teste de hipóteses, foi utilizado nível de probabilidade de 5\% (P< $0,05)$ e as tedências foram discutidas usado nível de probabilidade de $10 \%$ ( $\mathrm{P}<$ 
0,10). Quando as interações entre tratamento $x$ tempo não foram significativas $(P>0,10)$, a médias para todos horários de coleta foram apresentadas.

\subsection{RESULTADOS DE DISCUSSÃO}

\subsubsection{Composição química e tamanhos de partículas das forragens}

A composição química e distribuição de partículas por tamanhos do volumosos é apresentada na Tabela 2. Para a FDN, as concentrações mais elevadas foram verificadas na cana-de-açúcar "in natura" e tratada porém, o tratamento da cana-de-açúcar com $2 \%$ de solução de $\mathrm{NaOH} 50 \%$ não reduziu a porcentagem FDN, indicando que hemicelulose aparentemente não foi solubilizada ou a fração solubiliza foi utilizada pela planta ou por microrganismos para respiração. A utilização da fração solubilizada para respiração parece ser confirmada pelas porcentagens mais elevadas de FDN (+ $4,3 \%$ da $\mathrm{MO}$ ) e FDA (+ 5,2\% da $\mathrm{MO}$ ) e pela menor porcentagem de CNF (9,2\% da MO) da cana-de-açúcar tratada, quando comparada à cana-de-açúcar "in natura". Segundo Van Soest (1994), a FDN da forragem nem sempre é reduzida após o tratamento químico pois a respostas dependem da proporção de ligações lignina-carboidrato que são quebradas e do poder tampão do material tratado. Ezequiel et al. (2001a) também não observaram redução significativa na porcentagem de FDN quando compararam a cana-de-açúcar "in natura" a cana-de-açúcar tratada com solução de $\mathrm{NaOH} 50 \%$ na porcentagem de $1,5 \%(\mathrm{p} / \mathrm{v})$ da matéria fresca (42,9 vs. $41,9 \%$, respectivamente). As porcentagens de $2,0 \%$ e $4,0 \%$ da solução de $\mathrm{NaOH} 50 \%$ para tratamento da cana-de-açúcar também foram avaliadas por Alves et al (2001) que não encontraram diferenças para concentração FDN entre a cana-de-açúcar "in natura" (52,7\% de FDN) ou tratada na dose de 2,0\% (52,7\% de FDN). Na dose de $4,0 \%$ foi observada redução de cinco pontos percentuais na FDN indicando 
que a resposta ao tratamento depende da porcentagem da solução de $\mathrm{NaOH}$ empregada.

As forragens diferiram quanto a digestibilidade da FDN, conforme evidenciado pelas concentrações de FDNi e FDNpd (Tabela 2). A silagem de milho apresentou a porcentagem maior de FDNpd, provavelmente devido à proporção menor de lignificação (lignina/FDN) da parede celular desta forragem (5,2\% de lignina na FDN) quando comparada æ̀s demais. Outros fatores, além da lignificação da parede celular, também afetaram a porcentagem de FDNpd pois para o feno de alfafa, com proporção maior de lignificação da parede celular $(17,0 \%$ de lignina na FDN), foi observada uma porcentagem de FDNpd maior do que a observada para cana-de-açúcar "in natura" com proporção menor de lignificação (8,9\% de lignina na FDN).

Tabela 2. Composição química e distribuição de partículas por tamanhos dos volumosos.

\begin{tabular}{|c|c|c|c|c|}
\hline Composição & Silagem de milho & Cana-de-açúcar & $\begin{array}{c}\text { Cana-de-açúcar + } \\
\mathrm{NaOH}\end{array}$ & Feno de Alfafa \\
\hline MS, \% & 28,2 & 31,7 & 36,7 & 91,7 \\
\hline $\mathrm{MO}, \% \mathrm{MS}$ & 93,8 & 95,0 & 93,2 & 88,9 \\
\hline MM, \% MS & 6,2 & 5,0 & 6,8 & 11,1 \\
\hline FDA, \% MS & 23,9 & 32,2 & 33,6 & 25,9 \\
\hline FDN, \% MS & 44,5 & 57,1 & 58,9 & 38,5 \\
\hline Lignina, \% MS & 2,0 & 4,6 & 4,5 & 6,0 \\
\hline Lignina, \% FDN & 5,2 & 8,9 & 8,2 & 17,0 \\
\hline CNF, \% MS & 37,5 & 35,0 & 31,1 & 26,0 \\
\hline FDNI, \% MS ${ }^{1}$ & 16,0 & 31,7 & 26,4 & 19,4 \\
\hline FDAI, \% MS & 8,4 & 18,6 & 14,3 & 12,7 \\
\hline FDNpd, \% FDN ${ }^{2}$ & 64,0 & 44,5 & 55,2 & 49,7 \\
\hline $\mathrm{TMP}, \mathrm{mm}^{3}$ & 13,9 & 12,6 & 12,6 & 5,3 \\
\hline$<8 \mathrm{~mm}$ & 21,5 & 19,4 & 18,1 & 61,2 \\
\hline 8 a 19 mm & 51,8 & 66,0 & 67,3 & 24,5 \\
\hline$>19 \mathrm{~mm}$ & 26,7 & 14,6 & 14,6 & 14,3 \\
\hline
\end{tabular}

Isto também ficou evidenciado entre a cana-de-açúcar "in natura" e canade-açúcar tratada com $\mathrm{NaOH}$, pois apesar da pequena diferença de lignificação da parede celular destas forragens, o tratamento com álcali aumentou em $26 \%$ 
a porcentagem de FDNpd da cana-de-açúcar. Ezequiel et al. (2001c) observaram também aumento (52,6\%) para porcentagem de FDNpd da canade-açúcar quando a forragem foi tratada com solução de $\mathrm{NaOH} 50 \%$ na dose de $1,5 \%(\mathrm{p} / \mathrm{v})$. Em avaliações "in vivo", a digestibilidade de FDN da cana-deaçúcar também sido aumentada pelo tratamento com $\mathrm{NaOH}$ (Alves et al., 2001).

O tamanho médio de partículas (TMP) e a distribuição partículas por tamanhos da forragens são apresentas também na Tabela 2. Com exceção do feno alfafa, as demais forragens apresentaram TMP semelhantes porém, foram observadas diferenças quanto a distribuição de partículas. As variações observadas na distribuição de partículas por tamanho refletem as diferenças nos equipamentos e ajustes utilizados para o processamento das forragens durante a colheita ou picagem. Para o feno de alfafa, a maior porcentagem de partículas foi recuperada na fração $<8 \mathrm{~mm}$ que apresentam efetividade menor do que as partículas retidas nas peneiras de 8 e 19 mm (Buckmaster, 2000). Comparada às demais forragens, a silagem de milho foi que apresentou porcentagem maior de partículas $>19 \mathrm{~mm}$, inclusive superando a amplitude de 10 a 15\% de partículas acima de $19 \mathrm{~mm}$ proposta para silagem de milho por Heinrichs \& Lammers (1997). A porcentagem de partículas $>19 \mathrm{~mm}$ encontrada na silagem de milho favoreceria a seleção de componentes da dieta caso esta forragem fosse fornecida como volumoso único.

Considerando o limiar no TMP $(<3 \mathrm{~mm})$ das forragens a partir do qual foram observadas respostas significativas na atividade de mastigação (Allen, 1997) e a amplitude no TMP encontrada para as forragens aqui avaliadas (5,3 a $13,9 \mathrm{~mm}$ ), não seriam esperados efeitos significativos do TMP da forragens sobre a atividade de mastigação.

\subsubsection{Composição químicas das dietas}

A composição química das dietas é apresentada na Tabela 3. Para as dietas SMB e f.alfafa as porcentagens de MS foram mais elevadas do que para 
demais dietas devido proporção maior de alimentos concentrados utilizada na dieta SMB e a inclusão de forragem desidratada na dieta com feno de alfafa. Para concentração de PB ocorreram pequenas variações mas, em geral, todos os valores foram próximos do teor de $18 \%$ proposto inicialmente para 0 balanceamento das dietas. Os CNF foram calculados por diferença e concentração maior foi observada na dieta SMB, balanceada com porcentagem maior de alimentos concentrados $(71 \%$ da MS vs. 44 a $54 \%$ para as demais dietas). As dietas foram balanceadas para 22 e $28 \%$ de FDN total porém, as porcentagens observadas inferiores as concentrações inicialmente estabelecidas. Para FDN proveniente de silagem de milho, as porcentagens observadas nas cinco dietas foram também inferiores aos teores inicialmente estabelecidos no balanceamento (14 e 22\%, respectivamente). Para as porcentagens de FDN oriundas de cana-de-açúcar "in natura", cana-de-açúcar tratada com $\mathrm{NaOH}$ e feno de alfafa, os valores observados foram superiores ao objetivo inicial de inclusão de 8\% FDN a partir destas forragens.

Tabela 3. Composição química das dietas

\begin{tabular}{|c|c|c|c|c|c|}
\hline \multirow[b]{2}{*}{ Composição } & \multicolumn{5}{|c|}{ Dietas } \\
\hline & SMB & Cana & Cana $\mathrm{NaOH}$ & F.de Alfafa & SMA \\
\hline \multirow[t]{2}{*}{$\overline{M S}, \%$} & 54,5 & 47,1 & \multirow{2}{*}{$\begin{array}{c}47,7 \\
\% \text { da MS }\end{array}$} & 55,0 & 43,9 \\
\hline & & & & ----. & \\
\hline PB & 18,2 & 18,5 & 18,0 & 17,9 & 17,8 \\
\hline FDA & 9,3 & 13,8 & 14,3 & 14,7 & 13,5 \\
\hline CNF & 52,1 & 45,5 & 45,0 & 44,8 & 45,6 \\
\hline Lignina & 1,3 & 2,4 & 2,5 & 3,1 & 1,6 \\
\hline EE & 2,3 & 2,0 & 1,9 & 2,2 & 2,4 \\
\hline MM & 6,5 & 6,5 & 6,8 & 7,6 & 7,0 \\
\hline Volumoso & 29,4 & 43,8 & 44,8 & 54,4 & 47,4 \\
\hline $\mathrm{NDT}^{3}$ & 75,5 & 71,2 & 70,5 & 69,5 & 72,9 \\
\hline FDN total & 20,9 & 27,2 & 28,3 & 27,5 & 27,2 \\
\hline FDN Silagem de Milho & 13,2 & 13,3 & 13,3 & 13,0 & 21,3 \\
\hline FDN Cana-de-açúcar & & 8,3 & & & \\
\hline FDN Cana+NaOH & & & 9,3 & & \\
\hline FDN Feno de Alfafa & & & & 9,5 & \\
\hline FDN Concentrado & 7,7 & 6,0 & 5,8 & 4,8 & 5,9 \\
\hline $\mathrm{FDNpd}^{4}, \%$ da FDN total & 81,3 & 72,4 & 73,8 & 71,3 & 76,8 \\
\hline
\end{tabular}


As variações nas porcentagens e proporções de FDN refletem flutuações que ocorreram na composição dos volumosos no decorrer do experimento, quando comparadas æ̀s concentrações de FDN usadas inicialmente para o balanceamento das dietas.

\subsubsection{Consumo e digestibilidade}

Os consumos de MS e MO não foram afetados $(P>0,05)$ pelos tratamentos porém, o consumo de FDN da dieta SMB foi inferior $(P<0,05)$ ao das demais dietas (Tabela 4). Os resultados para consumo de FDN eram esperados porque a dieta SMB foi balanceada com concentração menor de FDN total (22\% vs. $28 \%$ ). O efeito da concentração e fonte de FDN sobre 0 consumo MS foi avaliado em alguns experimentos e, em geral, quando as dietas foram balanceadas para concentrações equivalentes de FDN não foram observados efeitos da fonte de FDN sobre o consumo de MS (Beauchemin, 1991; Mertens, 1995; Poore et al., 1991; Poore et al., 1993). Apesar destes resultados, é preciso considerar que a importância das variações na composição de FDN sobre o consumo de MS dependem das exigências de energia do animal e do efeito de repleção da dieta (Allen, 2000).

A amplitude de variação na composição e digestibilidade da FDNF no presente experimento foi, até certo ponto, limitada pela substituição apenas parcial da FDN de silagem de milho por FDN de outras forragens. Além disso, considerando o potencial médio de produção das vacas utilizadas neste trabalho (18,2 kg/dia), as dietas foram balanceadas para porcentagem de FDN próxima do mínimo sugerido pelo NRC (2001) e com proporção relativamente elevada de concentrados (70 a $45 \%$ da MS). Em outras trabalhos, a substituição parcial ou total da silagem de milho por cana-de-açúcar (menor digestibilidade de fibra e maior efeito de repleção) tem resultado em redução do 
consumo de MS e produção de leite (Mendonça et al., 2002; Ribeiro et al., 2000).

$\mathrm{Na}$ dieta com porcentagem maior de concentrados e menor de FDN total, as digestibilidades aparentes de MS e MO foram maiores $(P<0,05)$ do que nas dietas com cana, canaNaOH e f.alfafa. Por outro lado, para as dietas balanceadas com $22 \%$ de FDNF, houve redução na digestibilidade aparente de MS e MO $(P<0,05)$ quando a dieta SMA foi comparada æ̀ dietas com cana-deaçúcar e feno de alfafa. As dietas com cana-de-açúcar apresentaram tendência de maior digestibilidade de $M S$ e $M O(P=0,09$ e $P=0,09$, respectivamente), quando comparadas a dieta com feno de alfafa, porém o tratamento da 
Tabela 4. Consumo e digestibilidade em dietas onde parte da FDN de silagem milho foi substituída cana-de-açúcar ou feno de alfafa.

\begin{tabular}{|c|c|c|c|c|c|c|c|c|c|c|c|}
\hline \multirow[b]{2}{*}{ Item } & \multicolumn{5}{|c|}{ Dietas } & \multicolumn{2}{|c|}{$E P^{2}$} & \multicolumn{4}{|c|}{$P^{3}$} \\
\hline & SMB & Cana & cana $\mathrm{NaOH}$ & f.alfafa & SMA & $\mathrm{n}=4$ & $\mathrm{n}=5$ & SMB $\times$ FOR & SMA x FOR & Cana x FA & Cana \\
\hline $\begin{array}{l}\text { Consumo, } \mathrm{kg} / \mathrm{d} \\
\text { MS }\end{array}$ & 16,8 & 17,8 & 16,5 & 17,3 & 16,8 & 0,7 & 0,6 & NS & NS & NS & NS \\
\hline MO & 15,7 & 16,7 & 15,3 & 16,0 & 15,6 & 0,6 & 0,6 & NS & NS & NS & NS \\
\hline FDN & 3,51 & 4,90 & 4,66 & 4,76 & 4,60 & 0,19 & 0,17 & $<0,01$ & NS & NS & NS \\
\hline FDNpd & 2,85 & 3,51 & 3,45 & 3,39 & 3,51 & 0,14 & 0,12 & $<0,01$ & NS & NS & NS \\
\hline \multicolumn{12}{|c|}{ Digestibilidade, \% } \\
\hline MS & 73,2 & 65,5 & 68,6 & 64,5 & 61,8 & 1,1 & 0,9 & $<0,01$ & $<0,01$ & 0,09 & NS \\
\hline $\mathrm{MO}$ & 74,6 & 67,6 & 70,2 & 66,4 & 63,8 & 1,1 & 1,0 & $<0,01$ & $<0,01$ & 0,09 & NS \\
\hline \multicolumn{12}{|l|}{ FDN } \\
\hline Rúmen & 48,1 & 39,6 & 45,1 & 45,4 & 37,2 & 5,2 & 4,3 & NS & NS & NS & NS \\
\hline Trato total & 44,7 & 34,5 & 44,9 & 36,7 & 33,9 & 3,2 & 2,3 & NS & NS & NS & 0,05 \\
\hline \multicolumn{12}{|l|}{ FDNpd } \\
\hline Rúmen & 50,2 & 55,8 & 62,5 & 57,2 & 49,8 & 4,3 & 3,8 & NS & 0,06 & NS & NS \\
\hline Trato total & 60,2 & 48,6 & 65,2 & 56,3 & 48,6 & 3,6 & 3,1 & NS & 0,06 & NS & 0,01 \\
\hline
\end{tabular}

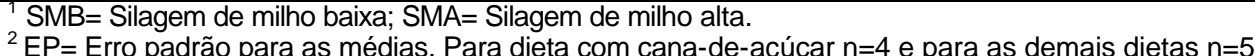

${ }_{3}$ Probabilidade de resposta para tratamentos; $N S=$ não significativa $(P>0,10)$. Contrastes comparam: $S M B \times F O R=a$ inclusão de $8 \%$ de FDN de três forragens a uma dieta basal com $14 \%$ de FDN de silagem de milho; SMA X FOR = $8 \%$ de FDN proveniente de silagem de milho à $8 \%$ de FDN proveniente de três forragens; Cana $x$ FA = $8 \%$ de FDN proveniente de cana-de-açúcar à $8 \%$ de FDN proveniente de feno de alfafa; Cana = 8\% de FDN proveniente de cana-de-açúcar "in natura" vs. $8 \%$ de FDN proveniente de cana-de-açúcar tratada com $\mathrm{NaOH}$.

$4 \mathrm{FDNpd}=$ FDN potencialmente digestível $=$ FDN total $(\%$ da MS $)-$ FDN indigestível in vitro $(\%$ da MS 
cana-de-açúcar com $\mathrm{NaOH}$ não afetou significativamente $(P>0,10)$ as digestibilidades aparentes de MS e MO.

As digestibilidades da FDN no rúmen não diferiram entre os tratamentos $(\mathrm{P}>0,10)$ porém, para a dieta com cana-de-açucar tratada com $\mathrm{NaOH}$ a digestibilidade de FDN no trato total foi maior $(P<0,05)$ do que para a dieta com cana-de-açúcar "in natura". Para digestibilidade da FDNpd, foi observada tendência de digestibilidade menor no rúmen e trato total $(P=0,06$ e $P=0,06$, respectivamente) para dieta SMA, quando comparada æ̀s dietas com cana, canaNaOH e f.alfafa. Para a dieta com cana-de-açúcar tratada $\mathrm{NaOH}$ a digestibilidade de FDNpd no trato total foi maior $(P<0,05)$ do que na dieta com cana-de-açúcar "in natura". Alves et al. (2001) também observaram digestibilidade da FDN foi maior para dietas com cana tratada com $\mathrm{NaOH}$, quando comparadas àdieta com cana "in natura" (31,7 vs. $23,8 \%$; $P<0,05)$.

Considerando a concentração de FDNpd das dietas (Tabela 3), o pH ruminal (Tabela 5) as taxas passagem de forragens (Tabela 6), as digestibilidades menores de MS, MO e FDNpd da dieta SMA, quando comparada æ̀̀ dietas cana, canaNaOH e f.alfafa, não eram esperadas. Magalhães et al. (2002) compararam a silagem de milho e cana-de-açúcar como volumosos para vacas em lactação e verificaram que as digestibilidades de MS e MO não diferiram entre os tratamentos, porém a substituição da silagem de milho por cana-de-açúcar reduziu significativamente a digestibilidade da FDN.

\subsubsection{Produção e composição do leite}

A produção e composição do leite não diferiram entre tratamentos (Tabela 5). Como não houve efeito de tratamentos sobre a porcentagem de gordura no leite, foi possível concluir que a FDN das forragens testadas apresentaram efetividades de FDN equivalentes à efetividade de FDN da 
silagem de milho. Clark \& Armentano (1999) também não observaram alterações produção ou porcentagem de gordura no leite quando compararam uma dieta com $22 \%$ de FDN proveniente de silagem de alfafa à dietas com $12 \%$ da FDN de silagem alfafa associada à $9 \%$ da FDN proveniente de silagem de milho. Por outro lado, a substituição parcial ou total da silagem de milho por cana-de-açúcar tem resultado em redução da produção de leite porém, sem efeitos significativos sobre o teor de gordura (Magalhães et al., 2000; Mendonça et al., 2001). A produção de leite menor observada nas dietas onde a cana-de-açúcar substituiu a silagem de milho foi freqüentemente associada à reduções do consumo de MS e da digestibilidade (Mendonça et al., 2002; Ribeiro et al., 2000)

Tabela 5. Produção e composição do leite em dietas onde parte da FDN de silagem milho foi substituída por cana-de-açúcar e feno de alfafa

\begin{tabular}{|c|c|c|c|c|c|c|c|}
\hline \multirow[b]{2}{*}{ Item } & \multicolumn{5}{|c|}{ Dietas 1} & \multicolumn{2}{|c|}{$E P^{2}$} \\
\hline & SMB & cana & cana $\mathrm{NaOH}$ & f.Alfafa & SMA & $\mathrm{n}=4$ & $\mathrm{n}=5$ \\
\hline Leite, $\mathrm{kg} / \mathrm{d}$ & 18,6 & 17,8 & $\overline{18,4}$ & 18,0 & 18,4 & 1,1 & 1,0 \\
\hline Leite $3,5 \% \mathrm{MG}, \mathrm{kg} / \mathrm{d}$ & 18,7 & 18,6 & 19,0 & 17,8 & 18,8 & 1,0 & 1,0 \\
\hline Gordura, \% & 3,60 & 3,72 & 3,70 & 3,43 & 3,63 & 0,17 & 0,15 \\
\hline Gordura, kg/d & 660 & 669 & 684 & 618 & 668 & 40 & 36 \\
\hline Proteína, \% & 3,39 & 3,44 & 3,33 & 3,38 & 3,26 & 0,12 & 0,12 \\
\hline Proteína, kg/d & 626 & 618 & 610 & 609 & 600 & 38 & 35 \\
\hline
\end{tabular}

\subsubsection{AGV e pH ruminal}

$\mathrm{Na}$ Tabela 6 são apresentados os resultados para AGV (AGV) e pH ruminal. $\mathrm{O} \mathrm{pH}$ ruminal não foi afetado pelo nível de FDNF porém, a inclusão da FDN de feno de alfafa $(F A)$ reduziu $(P=0,03)$ o $\mathrm{pH}$ ruminal, quando comparada àinclusão da FDN de cana -de-açúcar. Para as dietas com 22\% FDNF o pH ruminal manteve-se sempre acima de 6,0 porém, para dieta com 14\% FDNF $(\mathrm{SMB})$ o $\mathrm{pH}$ ruminal foi inferior 6,0 por, em média, até duas horas durante o dia. 
Tabela 6. pH do fluído ruminal e concentração de AGV em dietas onde parte da FDN de silagem milho foi substituída por cana-de-açúcar ou feno de alfafa

\begin{tabular}{|c|c|c|c|c|c|c|c|c|c|c|c|}
\hline \multirow[b]{2}{*}{ Item } & \multicolumn{5}{|c|}{ Dietas } & \multicolumn{2}{|c|}{$E P^{2}$} & \multicolumn{4}{|c|}{$P^{3}$} \\
\hline & SMB & cana & canaNaOH & f.alfafa & SMA & $\mathrm{n}=4$ & $\mathrm{n}=5$ & SMB $\times$ FOR & SMA x FOR & Cana x FA & Cana \\
\hline$\overline{\mathrm{pH}}$ & 6,24 & 6,35 & 6,38 & 6,23 & 6,27 & 0,17 & 0,16 & NS & NS & 0.03 & NS \\
\hline AGV total, $\mathrm{mM}$ & 122 & 123 & 115 & 128 & 122 & 6 & 5 & NS & NS & NS & NS \\
\hline \multicolumn{12}{|l|}{$\mathrm{AGV}, \mathrm{mol} / 100 \mathrm{~mol}$} \\
\hline Acético & 60,9 & 64,1 & 65,0 & 62,2 & 59,7 & 1,6 & 1,4 & 0,01 & $<0,01$ & 0,08 & NS \\
\hline Propiônico & 23,8 & 21,9 & 20,6 & 23,9 & 25,1 & 1,5 & 1,3 & NS & $<0,01$ & 0,01 & 0,07 \\
\hline Butírico & 11,4 & 10,5 & 10,9 & 10,5 & 11,3 & 0,4 & 0,3 & $<0,01$ & $<0,01$ & NS & NS \\
\hline Acetato:propionato & 2,71 & 2,94 & 3,23 & 2,72 & 2,47 & 0,23 & 0,20 & 0,07 & $<0,01$ & 0,02 & 0,05 \\
\hline
\end{tabular}

SMB= Silagem de milho baixa; SMA= Silagem de milho alta.

${ }^{2}$ EP $=$ Erro padrão para as médias. Para dieta com cana-de-açúcar $n=4$ e para as demais dietas $n=5$.

${ }^{3}$ Probabilidade de resposta para tratamentos; NS = não significativa $(P>0,10)$. Contrastes comparam: $S M B \times F O R=a$ inclusão de $8 \%$ de $F D N$ de três forragens a uma dieta basal com $14 \%$ de FDN de silagem de milho; SMA X FOR = $8 \%$ de FDN proveniente de silagem de milho à $8 \%$ de FDN proveniente de três forragens; Cana $\times$ FA = $8 \%$ de FDN proveniente de cana-de-açúcar à $8 \%$ de FDN proveniente de feno de alfafa; Cana $=8 \%$ de FD N proveniente de cana-de-açúcar "in natura" vs. $8 \%$ de FDN proveniente de cana-de-açúcar tratada com $\mathrm{NaOH}$. 
$\mathrm{O}$ pH ruminal inferior a 6,0 tem sido associado àredução na digestão de fibra (Sauvant \& Mertens, 1998) e o decréscimo de pH observado para dieta SMB pode ser explicado pela proporção maior de concentrado e substrato fermentescível (CNF) desta dieta, quando comparada às dietas com 22\% de FDNF. Além disso, alterações no padrão de consumo e atividade de ruminação podem ter determinado a queda do $\mathrm{pH}$ por intervalo curto de tempo. Entretanto, a queda de $\mathrm{pH}$ observada na dieta SMB não foi de magnitude suficiente para alterar a digestão de fibra.

A concentração total de AGV não foi afetada pelos tratamentos, porém as proporções molares dos ácidos e relação $C_{2}: C_{3}$ foram alteradas pelo teor $e$ fonte de FDNF (Tabela 6). Na dieta SMB houve tendência $(P=0,07)$ de redução na relação $\mathrm{C}_{2}: \mathrm{C}_{3}$ em decorrência da $(\mathrm{P}=0,01)$ proporção molar menor de ácido acético observada nesta dieta, quando comparada à dietas com cana, canaNaOH e f.alfafa. $\mathrm{Na}$ dieta SMA, tanto a redução $(P<0,01)$ na proporção molar de ácido acético quanto o aumento $(P<0,01)$ na proporção molar de ácido propiônico ocasionaram redução significativa $(P<0,01)$ da relação $C_{2}: C_{3}$, quando comparada æ̀ dietas com $\mathrm{c}$ ana, canaNaOH e f.alfafa. As dietas com cana-de-açúcar tenderam à aumentar $(P=0,08)$ a proporção molar de ácido acético e reduzir $(P 0,01)$ a de ácido propiônico, quando comparadas à dieta com feno de alfafa. $A$ relação $\mathrm{C}_{2}: \mathrm{C}_{3}$ das dietas com cana-de-açúcar foram significativemente $(P 0,02)$ maiores do que na dieta com feno de alfafa, refletindo as alterações nas proporções molares dos ácido acético e propiônico. $\mathrm{Na}$ dieta com canaNaOH houve tendência $(P=0,07)$ para redução na proporção molar de ácido propiônico e aumento ( $\mathrm{P} 0,05)$ na relação acetato:propionato, quando comparada àdieta com cana "in natura".

Embora com variações de magnitude menor, as proporções molares de ácido butírico também foram alteradas pelos tratamentos. Neste caso, as dietas com silagem de milho como único volumoso aumentaram ( $\mathrm{P}=0,06$ para $\mathrm{SMB} x$ FOR e $\mathrm{P}=0,01$ para SMA $\times$ FOR, respectivamente) a proporção molar de ácido 
butírico, quando comparadas à dietas CAN, CAS e FA, que não diferiram entre si.

A produção e porcentagem molar de AGV é determinada principalmente pelo substrato fermentado e pH ruminal (Russel, 1998). Assim, a concentração e composição de CNF das dietas ou capacidade de troca de cátions (CTC) das forragens possívelmente afetaram o padrão de fermentação ruminal. Como a CTC das forragens não avaliada neste trabalho não foi possivel avaliar seu papel sobre o padrão de fermentação ruminal. Apesar dos efeitos significativos de tratamentos sobre a relação $\mathrm{C}_{2}: \mathrm{C}_{3}$, os valores médios para as dietas foram superiores ao limite $(<2,0)$ considerado por Erdman (1988) para que não ocorresse redução no teor de gordura no leite.

\subsubsection{Taxa de passagem}

A taxa de passagem de sólidos foi alterada pelo teor e fonte de FDNF das dietas (Tabela 7). A redução na porcentagem de FDNF diminuiu $(P=0,03)$ a taxa de passagem da silagem de milho, quando comparada æ̀ dietas com cana, canaNaOH e f.alfafa. As taxas de passagem da cana-de-açúcar e feno de alfafa foram maiores do que para silagem de milho nos níveis de 14 e $22 \%$ FDNF ( $P<0,01$ e $P=0,02$, respectivamente) e a taxa de passagem foi menor ( $P$ 0,03) para cana-de-açúcar do que para o feno de alfafa. A taxa de passagem de líquidos não foi afeta pelo teor de FDNF das dietas, porém ela tendeu à aumentar $(\mathrm{P}=0,07)$ quando as dietas com cana-de-açúcar foram comparadas àdieta com feno de alfafa.

A redução observada na taxa de passagem para silagem de milho na dieta com 14\% FDNF provavelmente foi determinada por alterações no tempo de ruminação (Tabela 7), pois segundo Firkins et al. (1998), a redução no tamanho de partícula através da ruminação aumenta a probabilidade de passagem pelo rúmen. 
Tabela 7. Taxa de passagem de sólidos e líquidos em dietas onde parte da FDN de silagem milho foi substituída por cana-de-açúcar ou feno de alfafa.

\begin{tabular}{|c|c|c|c|c|c|c|c|c|c|c|c|}
\hline \multirow[b]{2}{*}{ Item } & \multicolumn{5}{|c|}{ Dietas } & \multicolumn{2}{|c|}{$E P^{2}$} & \multicolumn{4}{|c|}{$P^{3}$} \\
\hline & SMB & cana & canaNaOH & f.alfafa & SMA & $\mathrm{n}=4$ & $\mathrm{n}=5$ & SMB x FOR & SMA x FOR & Cana x FA & Cana \\
\hline Silagem de milho, $/ \mathrm{h}$ & 0,023 & 0,038 & 0,033 & 0,036 & 0,033 & 0,005 & 0,004 & 0,03 & NS & NS & NS \\
\hline Forragens, /h & 0,023 & 0,036 & 0,043 & 0,049 & 0,033 & 0,005 & 0,005 & $<0,01$ & 0,02 & 0,03 & NS \\
\hline Líquidos, /h & 0,065 & 0,079 & 0,083 & 0,064 & 0,064 & 0,010 & 0,009 & NS & NS & 0.07 & NS \\
\hline
\end{tabular}

TSMB= Silagem de milho baixa; SMA= Silagem de milho alta.

EP= Erro padrão para as médias. Para dieta com cana-de-acúcar $n=4$ e para as demais dietas $n=5$.

${ }^{3}$ Probabilidade de resposta para tratamentos; NS = não significativa $(P>0,10)$. Contrastes comparam: $S M B \times F O R=a$ inclusão de $8 \%$ de $F D N$ de três forragens a uma dieta basal com 14\% de FDN de silagem de milho; SMA X FOR = $8 \%$ de FDN proveniente de silagem de milho à $8 \%$ de FDN proveniente de três forragens; Cana $x$ FA = $8 \%$ de FDN proveniente de cana-de-açúcar à $8 \%$ de FDN proveniente de feno de alfafa; Cana = 8\% de FDN proveniente de cana -de-açúcar "in natura" vs. $8 \%$ de FDN proveniente de cana-de-açúcar tratada com $\mathrm{NaOH}$ 
A taxa de passagem maior do feno de alfafa, quando comparado àcana de-açúcar, pode ter sido determinada pelo tamanho médio e distribuição de partículas ou pela gravidade específica funcional das partículas destas forragens. Segundo Kaske \& Von Englehardt (1990), citados por Allen (1996), a densidade e tamanho de partículas responderam por $2 / 3$ da variação no tempo médio de retenção de partículas inertes no rúmen. A densidade depende da taxa de fermentação da FDNpd e da fração da FDN que é potencial fermentescível. As gramíneas geralmente têm uma fração de FDNpd maior e taxas de digestão da FDN mais lentas do que as leguminosas e, desta forma, as partículas de gramíneas tornam-se flutuantes por períodos mais prolongados (Allen, 1996). Como a porcentagem de FDNpd da cana-de-açúcar "in natura" foi inferior a da cana-de-açúcar tratada e semelhante a do feno de alfafa (Tabela 2), a diferença no tamanho e distribuição de partículas entre as forragens parece ter sido responsável pelo resultados encontrados.

\subsubsection{Comportamento ingestivo}

Na Tabela 8 são apresentados os dados de comportamento ingestivo. A taxa de ingestão ( $\mathrm{kg}$ de $\mathrm{MS} / \mathrm{h}$ ) não foi afetada pelo teor ou fonte de FDN. Os tempos de ingestão ( $\mathrm{min} / \mathrm{d}$ e $\mathrm{min} / \mathrm{kg}$ de $\mathrm{MS}$ ) não difereriam entre as dietas com $22 \%$ de FDNF, porém houve tendência $(P=0,09)$ para tempo menor de ingestão (min/d) no teor de $14 \%$ de FDNF. Quando expressos por unidade de FDN consumida ( $\mathrm{min} / \mathrm{kg}$ de FDN e min/kg de FDNF), o tempo de ingestão não diferiu entre as dietas com $22 \%$ de FDNF,porém foi.maior para dieta com $14 \%$ de FDNF quando comparada æ̀ dietas com cana, canaNaOH e f.alfafa.

Os tempos de ruminação e mastigação ( $\mathrm{min} / \mathrm{d}$ e $\mathrm{min} / \mathrm{kg}$ de $\mathrm{MS}$ ) não difereriam entre as dietas com 22\% de FDNF, porém foram menores $(P<0,01)$ na dieta com $14 \%$ de FDNF quando comparada æ̀s dietas com cana-de-açúcar e feno de alfafa (Tabela 8). Quando expressos por unidade de FDN consumida 
(min/kg de FDN e min/kg de FDNF), os tempos de ruminação e mastigação entre os tratamentos.

Estes resultados, combinados à ausência de efeito da FDNF sobre o teor de gordura no leite, reforçam a hipótese que as forragens avaliadas têm efetividades de fibra equivalentes. A atividadade de mastigação também não tem sido afeta pela fonte de FDN em trabalhos onde as dietas foram balanceadas para concentrações equivalentes de FDNF (Correa et al., 2000; Poore et al., 1993; Oba \& Allen, 2000). Por outro lado, Clark \& Armentano (1999) verificaram que a atividade de mastigação não foi afetada pelo tamanho de partícula da silagem de milho, porém, quando a FDN de silagem pré-secada de alfafa foi parcialmente substituida por silagem de milho, o tempo de ruminação foi mantido mas ocorreram reduções no tempo de ingestão e mastigação.

O aumento no tempo de ingestão e a manutenção dos tempos de ruminação e mastigação por unidade de FDNF na dieta com $14 \%$ de FDNF evidencia que vacas possuem um mecanismo adaptativo de compensação pelo qual a ruminação torna-se mais eficiente quando são oferecidas dietas com porcentagem baixa de FDN (Grant, 1997).

$\mathrm{Na}$ Tabela 9 são apresentados os coeficientes de efetividade da fibra da cana-de-açúcar, cana tratada com $\mathrm{NaOH}$ e feno de alfafa, calculados empregando-se a metodologia proposta por Mooney \& Allen (1997). Para efeito de comparação entre forragens, foi atribuido coeficiente de efetividade igual a 1,0 para silagem de milho, pois ela representou, neste tabalho, a forragem referência contra a qual todas as demais foram comparadas. Considerando os erros padrões das estimativas e os intervalos de confiança calculados para estes coeficientes (Tabela 9), conclui-se que as efetividades da FDN não diferiram entre as forragens. 
Tabela 8. Taxa de ingestão e tempos de ingestão, ruminação e mastigação em dietas onde parte da FDN de silagem milho foi substituída por cana-deaçúcar ou feno de alfafa.

\begin{tabular}{|c|c|c|c|c|c|c|c|c|c|c|c|}
\hline \multirow[b]{2}{*}{ Item } & \multicolumn{5}{|c|}{ Dietas1 } & \multicolumn{2}{|c|}{$E P^{3}$} & \multicolumn{4}{|c|}{$P^{3}$} \\
\hline & SMB & Cana & Cana $\mathrm{NaOH}$ & F. alfafa & SMA & $\mathrm{n}=4$ & $\mathrm{n}=5$ & SMB $\times$ FOR & SMA x FOR & Cana x FA & Cana \\
\hline \multicolumn{12}{|l|}{ Taxa de ingestão } \\
\hline $\mathrm{Kg}$ de $\mathrm{MS} / \mathrm{h}$ & 4,94 & 4,45 & 4,43 & 4,73 & 4,20 & 0,56 & 0,51 & NS & NS & NS & NS \\
\hline \multicolumn{12}{|l|}{ Ingestão } \\
\hline $\operatorname{Min} / \mathrm{d}$ & 213 & 258 & 237 & 242 & 256 & 30 & 29 & 0,09 & NS & NS & NS \\
\hline Min/kg de MS & 12,9 & 14,7 & 14,7 & 14,1 & 15,1 & 1,8 & 1,7 & NS & NS & NS & NS \\
\hline Min/kg de FDN & 61,5 & 53,1 & 52,6 & 51,0 & 55,2 & 6,6 & 6,2 & 0,04 & NS & NS & NS \\
\hline Min/kg de FFDN ${ }^{4}$ & 98 & 75 & 74 & 69 & 70 & 14 & 13 & $<0,01$ & NS & NS & NS \\
\hline \multicolumn{12}{|l|}{ Ruminação } \\
\hline Min/d & 266 & 403 & 406 & 395 & 368 & 32 & 28 & 0,09 & NS & NS & NS \\
\hline Min/kg de MS & 16,0 & 22,3 & 24,4 & 23,1 & 22,1 & 1,9 & 1,7 & $<0,01$ & NS & NS & NS \\
\hline Min/kg de FDN & 76,5 & 81,2 & 90,6 & 84,6 & 81,4 & 7,7 & 6,7 & NS & NS & NS & NS \\
\hline \multicolumn{12}{|l|}{ Mastigação } \\
\hline $\operatorname{Min} / \mathrm{d}$ & 479 & 661 & 644 & 637 & 624 & 40 & 36 & $<0,01$ & NS & NS & NS \\
\hline Min/kg de MS & 28,9 & 37,2 & 38,7 & 37,1 & 37,2 & 2,6 & 2,3 & $<0,01$ & NS & NS & NS \\
\hline Min/kg de FDN & 138 & 135 & 144 & 136 & 136 & 10 & 9 & NS & NS & NS & NS \\
\hline Min/kg de FFDN ${ }^{4}$ & 220 & 191 & 200 & 186 & 175 & 16 & 14 & NS & NS & NS & NS \\
\hline
\end{tabular}

${ }^{2} \mathrm{EP}=$ Erro padrão para as médias. Para dieta com cana-de-açúcar $n=4$ e para as demais dietas $n=5$.

2EP= Erro padrão para as médias. Para dieta com cana-de-açúcar $n=4$ e para as demais dietas $n=5$.
3 Probabilidade de resposta para tratamentos; NS = não significativa $(P>0,10)$. Contrastes comparam: SMB $\times$ FOR $=a$ inclusão de $8 \%$ de FDN de três forragens a uma dieta basal com $14 \%$ de FDN de silagem de milho; SMA X FOR = 8\% de FDN proveniente de silagem de milho à $8 \%$ de FDN proveniente de três forragens; Cana $x$ FA $=8 \%$ de FDN proveniente de cana-deaçícar à $8 \%$ de FDN proveniente de feno de alfáa; Cana $=8 \%$ de FDN proveniente de cana-de-açúcar "in natura" vs. $8 \%$ de FDN proveniente de cana-de-açúcar tratada com $\mathrm{NaOH}$

${ }^{4}$ FDNF = Fibra detergente neutra proveniente de forragem. Para as dietas SMB e SMA apenas FDN proveniente de silagem de milho e para as dietas CAN, CAS e FA representaFDN provenientede silagemde

milho mais a FDN proveniente de cana-de-açúcar, cana-de-açúcar $+2 \%$ de $\mathrm{NaOH}$ ou feno de alfafa. 
Tabela 9. Coeficientes de efetividade da FDN da cana-de-açúcar e feno de alfafa

\begin{tabular}{lccc}
\hline Forragem & Coeficiente & $\mathrm{EP}$ & $\mathrm{IC}^{\mathrm{I}}$ \\
\hline Cana-de-açúcar & 1,71 & 0,35 & $0,59-2,82$ \\
Cana tratada & 1,29 & 0,35 & $0,17-2,40$ \\
Feno de alfafa & 1,10 & & $0,48-1,90$ \\
\hline
\end{tabular}

1. EP= Erro padrão do coeficiente

2 Intervalo de confiança do coeficiente

\subsubsection{Consitência do "mat" ruminal}

Para consistência do "mat" ruminal houve tendência para interação entre tratamento $\times$ tempo $(P=0,06)$ e resultados foram apresentados considerando a interação (Tabela 8). Para as medidas efetuadas duas e quatro horas após a alimentação, foi observada uma redução ( $P=0,04$ e $P=0,09$, respectivamente) na consistência do "mat" para dieta com $22 \%$ da FDNF proveniente de silagem de milho, quando comparada às dietas com mesmo nível de FDNF. Para dieta com 14\% de FDNF foram observadas reduções na consistência do "mat " ruminal quatro e seis horas após a alimentação, quando comparada æ̀s CAN, CAS e FA, com $22 \%$ de FDNF. O valores médios de consistência do "mat" foram também inferiores nas dietas com 14 e 22\% FDNF proveniente de silagem de milho ( $P<0,01$ e $P=0,04$, respectivamente), quando comparadas ̀̀ dietas com cana-de-açúcar e feno de alfafa. Esta combinação de resultados indica que, a silagem de milho como volumoso único reduz a consistência "mat", quando comparadas àdietas contendo cana -de-açúcar ou feno de alfafa. Para dieta com 14\% de FDNF, a consistência do "mat" foi reduzida significativamente $(P=0,05)$ entre as medidas efetuadas duas e seis horas após a alimentação. 


\subsection{CONCLUSÕES}

A porcentagem de gordura no leite e a atividade de mastigação não diferiram entre os tratamentos com $22 \%$ de FDNF, apesar das variações observadas no tamanho de partículas e na composição da FDN das forragens e no padrão de fermentação ruminal (relação acetato:propionato).

A consistência do "mat" foi afetada pelos tratamentos, porém a resposta não foi de amplitude suficiente para afetar diretamente à atividade de mastigação. Mesmo considerando ser esta uma medida auxiliar e não direta de avaliação da efetividade da fibra, o erro padrão para esta variável sugere ser necessário o desenvolvimento de metodologias mais precisas e acuradas de determinação.

A partir dos resultados de teor de gordura no leite e comportamento ingestivo, conclui-se que as amplitudes no tamanho de partículs e composição de FDNF utilizadas neste trabalho não afetaram os coeficientes de efetividade física da FDN estimados para as forragens.. 
Tabela 10.. Consistência do "mat" ruminal em dietas onde parte da FDN de silagem milho foi substituída por cana-de-açúcar ou feno de alfafa

\begin{tabular}{|c|c|c|c|c|c|c|c|c|c|c|c|}
\hline \multirow[b]{2}{*}{ Item } & \multicolumn{5}{|c|}{ Dietas1 } & \multicolumn{2}{|c|}{$\mathrm{EP}^{3}$} & \multicolumn{4}{|c|}{$P^{3}$} \\
\hline & SMB & Cana & Cana $\mathrm{NaOH}$ & F. alfafa & SMA & $n=4$ & $n=5$ & SMB $\times$ FOR & SMA x FOR & Cana x FA & Cana \\
\hline \multicolumn{12}{|c|}{ Tx. ascensão, cm/s } \\
\hline 2 horas & 0,27 & 0,14 & 0,16 & 0,16 & 0,35 & 0,10 & 0,09 & NS & 0,04 & NS & NS \\
\hline 4 horas & 0,43 & 0,12 & 0,17 & 0,20 & 0,34 & 0,10 & 0,09 & 0,02 & 0,09 & NS & NS \\
\hline 6 horas & 0,73 & 0,14 & 0,22 & 0,24 & 0,30 & 0,11 & 0,10 & $<0,01$ & NS & NS & NS \\
\hline Média & 0,48 & 0,13 & 0,18 & 0,20 & 0,33 & 0,09 & 0,08 & $<0,01$ & 0,04 & NS & NS \\
\hline
\end{tabular}

${ }_{1}^{1}$ SMB= Silagem de milho baixa; SMA= Silagem de milho alta; CAN= Cana-de-açúcar; CAS= Cana-de-açúcar $+2 \%$ de NaOH; FA= Feno de alfafa,

${ }^{2} \mathrm{EP}=$ Erro padrão para as médias, Para dieta com cana-de-açúcar $n=4$ e para as demais dietas $n=5$,

${ }^{3}$ Probabilidade de resposta para tratamentos; $N S=$ não significativa $(P>0,10)$. Contrastes comparam: $S M B \times F O R=a$ inclusão de $8 \%$ de FDN de três forragens a uma dieta basal com $14 \%$ de $F D N$ de silagem de milho; SMA X FOR $=8 \%$ de FDN proveniente de silagem de milho à $8 \%$ de FDN proveniente de três forragens; Cana x FA = 8\% de FDN proveniente de canadeaçúcarà $8 \%$ de FDN proveniente de feno de allafa; Cana $=8 \%$ de FDN proveniente de cana-de-açúcar "in natura" vs. $8 \%$ de FDN proveniente de cana-de-açúcar tratada com $\mathrm{NaOH}$ 


\section{ANÁLISE COMPARATIVA DA EFETIVIDADE DA FIBRA DE SUBPRODUTOS}

\section{Resumo}

Seis vacas holandesas com cânulas no rúmen foram utilizadas em um delineamento quadrado latino $6 \times 6$ para avaliar a importância da presença de linter ou tamanho de partícula do caroço de algodão na sustentação da função ruminal e atividade de mastigação em dietas com porcentagem baixa de FDN de forragem. Quatro formas de processamento do caroço foram avaliadas e as vacas receberam seis dietas completas que constituíram os seguintes tratamentos: Dieta baixa forragem (DBF) - dieta com 16\% de FDN de forragem (FDNF); Dieta alta forragem (DAF) - dieta com 21\% de FDNF; linter - dieta com $16 \%$ de FDNF + $5 \%$ de FDN de caroço de algodão integral; amido - dieta com $16 \%$ de FDNF + $5 \%$ de FDN de caroço de algodão tratado com amido gelatinizado de milho; sem linter - dieta com 16\% de FDNF + 5\% de FDN de caroço sem linter; peletizada - dieta com 16\% de FDNF + 5\% de FDN de caroço peletizado. $O$ consumo de matéria seca não foi afetado pela forma de processamento do caroço de algodão, porém consumo de MS aumentou quando as dietas com caroço foram comparadas à dieta com $21 \%$ de FDN. A produção de leite foi maior para dieta com $16 \%$ de FDNF, porém não houve efeito de tratamento sobre a porcentagem de gordura no leite. Os tempos de ruminação e mastigação ( $\mathrm{min} / \mathrm{kg}$ de $\mathrm{MS}$ e $\mathrm{min} / \mathrm{kg}$ de FDN) foram menores nas dietas com caroço de algodão, quando comparadas àdieta com $21 \%$ de FDNF. 
A efetividade da fibra de caroço de algodão foi inferior à da forragem. Não foi possível definir se o linter ou o tamanho de partículas foram os fatores determinantes da efetividade do caroço de algodão.

\section{Summary}

Six ruminally cannulated Holstein cows were used in a $6 \times 6$ Latin square design to isolate the roles of specific fractions of whole cottonseeds in sustaining rumen function as mesuared by mat consistency, particulate passage rate, and chewing response. Whole cottonseeds (WCS), starch-coated WCS (EAS), mechanically delinted cottonseed (DEL) and pelleted WCS (PEL) were used and the six dietary treatments were: Low forage diet (LFD) $-16 \%$ of DM from forage NDF (FDNF); High forage diet (HFD) - $21 \%$ of DM from FDNF; WCS $-16 \%$ FDNF plus $5 \%$ of DM from WCS NDF; EAS - $16 \%$ FDNF plus $5 \%$ of DM from EAS cottonseed; DEL - 16\% FDNF plus 5\% of DM from DEL cottonseed, and PEL - 16\% FDNF plus 5\% of DM from pelleted WCS. Dry matter intake did not differ across cottonseed treatments but, it was higher than HFD treatment. Milk yield was higher for LFD but, milk fat percentage was not affected treatments. Ruminating and chewing activity were lower for cottonseed diets than HFD. Fiber effectiveness was lower for cottonseed and it was not possible to isolate the roles of linter or particle size in sustaining rumen function and chewing activity.

\subsection{INTRODUÇÃO}

A fibra é componente essencial da dieta de vacas em lactação, sendo necessária para obtenção de consumo máximo de MS e energia, para estimular a atividade de mastigação e secreção de saliva e manter porcentagem de gordura no leite. Assim, dietas de vacas em lactação devem 
ser balanceadas com uma porcentagem mínima de fibra que mantenha à função ruminal normal e evite à ocorrência de distúrbios metabólicos. Por outro lado, a fibra representa a fração de carboidratos dos alimentos de digestão lenta e variável e, quando incluida acima de determinados limites, definidos principalmente pelo potencial de produção do animal, pode limitar o consumo de MS e desempenho.

Os limites de fibra em dietas bovinos leiteiros são definidos não apenas por concentrações mínimas e máximas, mas também por atributos físicos, químicos e biológicos dos alimentos utilizados nas formulações de dietas. Desta forma, novos conceitos para balanceamento de dieta vêm sendo elaborados e incorporados a formulação de dietas de bovinos leiteiros. O NRC (1989) sugere que dietas de vacas em lactação devem conter, no mínimo, 25 a $28 \%$ de FDN total com $75 \%$ deste total sendo suprido por forragens. Além disso, o NRC (1989) sugere também que pelo um terço da MS da dieta deve ser fornecido por feno de fibra longa ou seus equilaventes, renconhecendo a importância de atributos físicos para o balanceamento de dietas. Quando as forragens são picadas com tamanho de partícula adequado, o NRC (2001) sugere, em sua edição mais recente, que as dietas de vacas em lactação devem ser balanceadas com, no mínimo, 25\% de FDN total e 19\% de FDNF.

Dois novos conceitos para o balanceamento de dieta foram desenvolvidos visando considerar não apenas a concentração da FDN nos alimentos mas também atributos físicos e biológicos que afetem a atividade de mastigação e teor de gordura no leite (Mertens, 1997). O conceito de fibra fisicamente efetiva (FDNfe) visa incorporar na definição de exigências de fibra atributos físicos (principalmente tamanho de partículas) relacionados à atividade de mastigação e a estratificação bifásica do conteúdo ruminal (Mertens, 1997). Por outro lado, a fibra efetiva (FDNe) está relacionada a habilidade de um alimento qualquer para substituir uma forragem e ainda assim manter a porcentagem de gordura no leite (Mertens, 1997). Assim, variações no tamanho de partículas ou em outros atributos dos alimentos (digestibilidade 
da fibra) que contribuem para alterar a atividade de mastigaçao e, ou, teor de gordura no leite podem afetar os valores de FDNef e FDNe.

A utilização de subprodutos em dietas de bovinos leiteiros contribui para reduzir custos de produção e a importância destes alimentos como fontes de fibra para bovinos leiteiros vem sendo pesquisada recentemente. Neste caso, o objetivo principal é substituir forragens em situações onde a inclusão de volumosos nas dietas é limitada pela qualidade ou disponibilidade da forragem. Avaliações de efetividade da fibra indicaram que, em média, a FDN de FFNF apresentou aproximadamente metade da efetividade da FDN de silagem de alfafa em manter a porcentagem de gordura no leite (Swain \& Armentano, 1994) e menos da metade da efetividade da FDN de forragem para estimular a atividade de mastigação (Firkins, 1995). Além disso, os valores de efetividade destes alimentos variaram consideramente e, na maioria destes estudos, as FFNF avaliadas apresentavam tamanho reduzido de partículas e, portanto, capacidade menor de estimular a mastigação.

Quando utilizado para substituir parte da FDNF, o caroço integral de algodão diferencia-se das demais FFNF quanto a capacidade para estimular a mastigação e manter o teor de gordura no leite (Clark \& Armentano, 1993; Mooney \& Allen, 1997; Firkins et al., 2002; Harvatine et al. 2002a; Harvatine et al., 2002b). Neste caso, aumentos no consumo de MS e produção de leite e manutenção da atividade de mastigação e teor de gordura no leite foram verificados com frequência. Coppock et al. (1985) sugeriam que o linter presente no caroço de algodão favorecia a retenção do caroço e outros componentes da dieta no rúmen, que seriam regurgitados e mastigados durante a ruminação. Estes autores utilizaram seis vacas em lactação para comparar a excreção de caroço de algodão com e sem linter e observaram que apenas $0,4 \%$ do caroço com linter era excretado nas fezes, comparado à $11,3 \%$ para o caroço sem linter.

A presença de linter no caroço aparentemente diminui a taxa de passagem das dietas, e deste modo, altera o enchimento ruminal e a 
consistência do "mat", o que explica parte da resposta observada na atividade de mastigação (Harvatine et al., 2002b).Estes autores observaram que a taxa de passagem de forragem diminuiu e a massa de FDN no rúmen $(\mathrm{kg})$ aumentou quando substituíram parte da FDN de silagem de alfafa por caroço de algodão $O$ linter é composto por celulose com alto grau de cristalização e taxa de degradação baixa (Palmquist, 1995), embora a celulose possa ser quase que completamente hidrolisada ao permanecer por períodos prolongados no rúmen.

Em estudos nos quais o linter foi completamente revestido por amido gelatinizado de milho (Bernard, 1999; Bernard et al., 1999), a produção de leite foi semelhante para dieta controle e com caroço tratado. $O$ tratamento do caroço não reduziu a porcentagem de gordura no leite nestes estudos, porém as concentrações de FDN total (39 e $36 \%$ da MS, respectivamente) e FDNF (25 e $22 \%$ da MS, respectivamente) das dietas foram adequadas e a fibra do caroço de algodão não era aparentemente necessária. Quando incluidos em dietas com baixa porcentagem de FDNF (15\% da MS), o caroço tratado com amido reduziu $(3,20$ vs. $3,53 \%$; $P<0,01)$ a porcentagem de gordura no leite quando comparado ao caroço integral (Firkins et al., 2002). Em dietas com porcentagem baixa de forragem, o linter, com sua taxa de degradação baixa, contribui reter de outros componentes da dieta no rúmen, aumentar o enchimento ruminal e promover atividade de mastigação semelhante à observada nas dietas com porcentagem mais elevada de FDNF.

Este trabalho teve como objetivo avaliar os mecanismos pelos quais o caroço de algodão estimula à atividade mastigação em dietas com baixa porcentagem de forragem. Os papeis da presença de linter e tamanho de partícula foram avaliados quanto a capacidade para manter a função ruminal, avaliada através atividade de mastigação, da consistência do "mat" ruminal e cinética do rúmen. 


\subsection{MATERIAL E MÉTODOS}

\subsubsection{Animais, tratamentos e delineamento experimental}

O trabalho foi desenvolvido no galpão para ensaios metabólicos da fazenda de gado leiteiro da The Ohio State University, em Columbus $-\mathrm{OH}$, EUA, entre os meses de março e junho de 2002. Foram utilizadas 6 vacas da raça holandesa em lactação, com cânulas no rúmen, que foram distribuídas em um delineamento quadrado latino $6 \times 6$. As vacas foram alojadas em baias individuais equipadas com comedouro e bebedouro e, no início do experimento, estavam com 80, 99, 105, 211, 216 e 217 dias em lactação e produção média de 33,0 kg/d. As vacas receberam injeções de $500 \mathrm{mg}$ de somatropina bovina sintética (bST) a cada 14 dias durante o experimento.

Nas seis dietas experimentais (Tabela 11), o feno de alfafa e feno de gramínea (3:1 em \% da MS) foram usados como volumosos. As dietas foram balanceadas para vacas em lactação com $590 \mathrm{~kg}$ de PV, produzindo $31 \mathrm{~kg}$ de leite com 3,5\% de gordura, 3,3\% de proteína e 90 dias de lactação. O NRC (2001) foi utilizado para o balanceamento das dietas com teores equivalentes de nutrientes ( $30 \%$ de FDN total, $40 \%$ de CNF e $18 \%$ de PB), exceto para as concentrações e composições da FDN, que foram alteradas de acordo com os tratamentos propostos. Os dados de composição de alguns alimentos (milho triturado, farelo de soja, semente de soja tostada, casca de soja) contidos na biblioteca do NRC (2001) foram utilizados no balanceamento das dietas.

Os demais alimentos (feno de alfafa, feno de gramínea e caroço de algodão) foram previamente analisados para determinação de $M S, M M$ e PB (AOAC, 1990), FDN e FDA (Van Soest, 1991) e ácidos graxos (Sukhija e Palmquist, 1988). O balanceamento das dietas foi então efetuado considerando dados de composição de alimentos da biblioteca do NRC (2001) e as análises realizadas no laboratório. 
Tabela 11. Composição de ingredientes das dietas

\begin{tabular}{|c|c|c|c|c|c|c|}
\hline \multirow[b]{2}{*}{ Composição } & \multirow[b]{2}{*}{$\mathrm{DBF}^{1}$} & \multicolumn{4}{|c|}{ Caroço de algodão } & \multirow[b]{2}{*}{$\mathrm{DAF}^{1}$} \\
\hline & & integral & amido & sem linter & peletizado & \\
\hline & & & da MS d & dieta- & & \\
\hline Feno de alfafa & 29,04 & 29,04 & 29,04 & 29,04 & 29,04 & 37,95 \\
\hline Feno de gramínea & 9,62 & 9,62 & 9,62 & 9,62 & 9,62 & 12,65 \\
\hline Caroço de algodão & - & 10,15 & 10,40 & 12,50 & 12,17 & - \\
\hline Resíduo de cervejaria & 9,70 & 9,70 & 9,70 & 9,70 & 9,70 & 9,70 \\
\hline Casca de soja & 7,78 & 0,72 & 0,82 & 2,20 & 1,80 & - \\
\hline Farelo de soja, $48 \%$ PB & 1,80 & 2,40 & 1,25 & 4,55 & 3,22 & - \\
\hline Semente de soja tostada & 8,77 & 5,20 & 6,25 & - & 2,12 & - \\
\hline Milho triturado & 26,81 & 28,44 & 28,19 & 27,66 & 27,60 & 24,74 \\
\hline Sebo bovino & 1,67 & - & - & - & - & 1,67 \\
\hline Peletes de $\mathrm{Cr}_{3} \mathrm{O}_{2}{ }^{2}$ & 2,75 & 2,75 & 2,75 & 2,75 & 2,75 & 2,75 \\
\hline Calcário & 0,71 & 0,81 & 0,81 & 0,81 & 0,81 & 0,45 \\
\hline Fosfato monossódio & 0,55 & 0,40 & 0,40 & 0,40 & 0,40 & 0,55 \\
\hline Óxido de magnésio & 0,15 & 0,12 & 0,12 & 0,12 & 0,12 & 0,12 \\
\hline Premix micro minerais $^{3}$ & 0,50 & 0,50 & 0,50 & 0,50 & 0,50 & 0,50 \\
\hline Premix vitamínico ${ }^{4}$ & 0,15 & 0,15 & 0,15 & 0,15 & 0,15 & 0,15 \\
\hline
\end{tabular}

${ }^{1}$ DBF $=$ Dieta baixa em forragem e DAF $=$ Dieta alta em forragem.

${ }^{2}$ Casca de soja $=83 \%$; melaço em pó $=15 \%$; e $\mathrm{Cr}_{3} \mathrm{O}_{2}=2 \%$.

${ }^{3}$ Contêm $0,10 \%$ de $\mathrm{Mg}, 38,0 \%$ de Na; $58 \%$ de Cl; $0,04 \%$ de S; $5000 \mathrm{mg} / \mathrm{kg}$ de Fe; $7500 \mathrm{mg} / \mathrm{kg}$ de Zn; $2500 \mathrm{mg} / \mathrm{kg}$ de $\mathrm{Cu} ; 6000 \mathrm{mg} / \mathrm{kg}$ de $\mathrm{Mn} ; 100 \mathrm{mg} / \mathrm{kg}$ de l; $60 \mathrm{mg} / \mathrm{kg}$ de Se; e $50 \mathrm{mg} / \mathrm{kg}$ de Co.

${ }^{4}$ Fornece aproximadamente $150000 \mathrm{UI}$ de Vit. A; $29000 \mathrm{UI}$ de Vit. D; e 544 UI de Vit. E/d.

A dieta com porcentagem baixa de FDNF (DBF) foi balanceada com $16 \%$ de FDN proveniente de feno de alfafa e feno de gramínea e 30\% de FDN total. A dieta com porcentagem alta de FDNF (DAF) foi balanceada com $21 \%$ de FDNF proveniente de feno de alfafa e feno de gramínea e 30\% de FDN total. Estas dietas representavam os controles negativo e positivo, respectivamente, e foram comparadas à quatro dietas que incluiam 16\% de FDN proveniente de feno de alfafa e feno de gramíneas e $5 \%$ de FDN proveniente de caroço de algodão processado, a partir do qual foram formuladas mais quatro dietas experimentais. Para formulação das dietas com caroço de algodão, foram utilizados o caroço integral, o caroço tratado com amido gelatinizado de milho, o caroço sem linter (removido mecanicamente) e o caroço peletizado. As formas de processamento foram selecionadas para avaliar a importância do linter (caroço integral, tratado com amido e sem linter) e tamanho de partícula (peletizado) para efetividade da fibra do caroço. 
Originalmente, o tratamento do caroço com amido gelatinizado de milho tem por objetivo revestir o linter e melhorar características de manipulação do caroço (Bernard, 1999). Já os processos de remoção mecânica do linter e peletização foram desevolvidos com o objetivo de aumentar da densidade do subproduto e reduzir custos com o frete.

\subsubsection{Amostragens e análises laboratoriais}

O experimento teve a duração de 90 dias, divididos em seis períodos de 15 dias, sendo oito dias de adaptação as rações e sete dias de coletas. As rações foram preparadas uma vez ao dia após as pesagens e mistura de todos os ingredientes; e fornecidas "ad libitum" em duas refeições as 6:00 e 18:00 horas. Para aumentar a porcentagem de umidade e reduzir a seletividade das dietas, resíduo úmido de cervejaria e água foram adicionados à mistura total. Para mistura das dietas foi utilizado um misturador horizontal e empregou-se um tempo mínimo de mistura de seis minutos por dieta. A quantidae da mistura total foi ajustada diariamente para garantir uma sobra de $3 \%$ do oferecido. $O$ ajuste para porcentagem baixa de sobras visava também reduzir a seletividade nas dietas. Os ingredientes e rações completas foram amostrados do nono ao décimo-segundo dia, e as sobras do décimo ao décimo-terceiro dia de cada período. As amostras foram congeladas e, ao final de cada período, reunidas para formar uma amostra composta por ingredientes e ração completa. Posteriormente, as amostras foram secas em estufa de ventilação forçada a $65^{\circ} \mathrm{C}$ por 48 horas.

As vacas foram ordenhadas diariamente æ̀ 4:30 e 15:30, e a produção de leite controlada a cada ordenha. Amostras de leite das ordenhas da manhã e da tarde foram tomadas do nono ao décimo-primeiro de cada período, conservadas com bromopol, refrigeradas, e posteriormente analisadas pelo DHI Cooperative Inc. (Powell, $\mathrm{OH}$ ), para determinação das concentrações de 
gordura, proteína, lactose e sólidos totais, utilizando equipamento de espectrocospia infravermelha e, para concentração de nitrogênio uréico no leite utilizando analisador de fluxo segmentado (Skalar SAN Plus, Skalar, Inc. Norcross, GA). As concentrações e produções de gordura e proteína foram calculadas por cada vaca e período, considerando as produções e composições do leite das amostras tomadas diariamente. As concentrações médias de componentes (gordura e proteína) e nitrogênio uréico no leite foram obtidas dividindo-se a produção total do componente no período, pela produção total de leite no mesmo período. As vacas foram pesadas semanalmente, antes da ordenha da tarde, e o peso vivo (PV) médio calculado em cada período.

As vacas foram monitoradas para determinação da atividade de mastigação durante um período contínuo de 24 horas no nono dia de cada período de coleta (Weidner \& Grant, 1994b). As atividades de ingestão, ruminação e ócio foram monitoradas a cada cinco minutos e o tempo total dispendido em cada atividade ( $\mathrm{min} / \mathrm{dia}$ ) foi calculado multiplicando-se o número total de observações em cada atividadade por cinco. O tempo mastigação foi calculado pela soma dos tempos despendidos com as atividades de ingestão e ruminação. Os tempos despendidos nestas atividades (ingestão, ruminação e mastigação) por kg de MS e FDN consumidos, foram calculados dividindo-se o tempo total em cada atividade pelos consumos de MS e FDN. O comportamento ingestivo das vacas não foi monitorado as ordenhas (128 min/período) e os tempos despendidos em cada atividade foram ajustados proporcionamente para 24 horas utilizando a seguinte equação (Harvatine et al., 2002):

Tempo ajustado, $\mathrm{min} / \mathrm{d}=$ (tempo despendido na atividade $\times 1440$ ) (1440 - tempo despendido na ordenha em minutos)

Os coeficientes de efetividade da fibra e intervalo de confiança para estas estimativas foram obtidos de acordo acordo com a metodologia utilizada por Mooney \& Allen (1997). Neste caso, foi também utilizada estimativa de atividade basal de mastigação calculada por este autores (355 min/d). 
A consistência do "mat" ruminal foi avaliada 2 e 6 horas após a alimentação da manhã no décimo dia, e 4 horas após a alimentação da manhã no décimo-primeiro dia dos períodos de coleta (Weidner \& Grant, 1994a), Um peso de metal de $454 \mathrm{~g}$ amarrado à um cordão de náilon foi inserido no saco ventral do rúmen, atravessando a camada flutuante de partículas, duas horas antes da tomada de cada medida. Após o período de duas horas para estabilização da camada flutuante do rúmen, a extremidade externa do cordão de náilon foi fixada àum peso de metal externo de $1362 \mathrm{~g}$ e foram computadas as distâncias de ascendência do peso interno a cada 20 segundos, por nove minutos. As taxas de ascensão do peso interno foram calculadas para os tempos de 1, 2, 5 e 9 minutos e dividindo-se o deslocamento total $(\mathrm{cm})$ pelos quatro tempos de referência (s).

Para determinação da taxa de passagem de fluídos, uma solução (100 $\mathrm{mL}$ ) contendo $15 \mathrm{~g}$ de CoEDTA foi introduzida no rúmen, antes da alimentação da manhã, no décimo-segundo dia dos períodos de coleta (Uden et al., 1980) e, em seguida, o conteúdo ruminal foi misturado manualmente. Antes das dosagens, amostras de dez pontos do conteúdo ruminal $(+1000 \mathrm{~mL})$ foram tomadas para determinação da concentração de Co, sendo este valor utilizado para correção das concentração de Co nos demais horários de coletas ("background"). Em seguida, amostras de dez pontos do conteúdo ruminal, foram tomadas 30 minutos, 1, 2, 4, 6, 9, 12, 18, 24 e 36 horas após a dosagem e uma subamostra $( \pm 1000 \mathrm{~mL}$ ) foi espremida para retirada de uma alíquota de $50 \mathrm{~mL}$ do fluído ruminal, que foi armezanada em freezer $\left(-4^{0} \mathrm{C}\right)$. Após o descongelamento, o fluído ruminal foi misturado e centrifugado $\left(15.000 \times \mathrm{g}\right.$ a $4^{0}$ C por $20 \mathrm{~min}$ ). Amostras do sobrenadantes e dose foram analisadas para concentração de Co, fazendo-se as leituras em espectrofotômetro de absorção atômica (Uden et al., 1980). As taxas de passagem de fluídos foram determinadas pela regressão do logaritmo natural (In) das concentrações de Co, corrigidas para concentração no tempo zero, contra os tempos de coleta (Faichney, 1975). 
Amostras de cinco pontos do conteúdo ruminal $( \pm 600 \mathrm{~mL}$ ) foram retiradas do rúmen 3, 6, 9 e 12 horas após a alimentação da manhã no décimoterceiro dia de cada período. O conteúdo foi espremindo e coado em duas camadas de pano de queijo e o $\mathrm{pH}$ do fuido ruminal avaliado imediatamente. Alíquotas de $50 \mathrm{~mL}$ de fluído ruminal foram acidificadas com $3 \mathrm{~mL}$ de $\mathrm{HCl} 6 \mathrm{~N}$ para interromper a fermentação, e em seguida armazenadas em freezer $\left(-4^{0}\right.$ C). Após as amostragens, o conteúdo ruminal foi retornado para o rúmen.

O conteúdo ruminal foi evacuado completamente 2 horas antes da alimentação no décimo-quarto dia e 2 horas após a alimentação no décimoquinto dia 15 de cada período (Dado e Allen, 1995). Para facilitar à coleta de subamostras, o conteúdo foi espremido com as mãos para separação de sólidos e líquidos. Uma separação adicional de sólidos e líquidos foi efetuada pela filtragem da porção líquida através de uma peneira (5 $\mathrm{mm}$ de poros). Subamostras de $5 \%$ do peso total de sólidos e liquidos foram retiradas, reconstituidas e em seguida congeladas. Após as amostragens, o conteúdo ruminal foi imediatemente retornado para o rúmen e, visando proporcionar adaptação mais rápida à nova dieta, trocava -se aproximadamente $5 \%$ do conteúdo total entre as vacas no segundo dia de coleta (décimo-quinto). As amostras de digesta ruminal $(\neq 1,5 \mathrm{~kg})$ foram secas em estufa a $65^{\circ} \mathrm{C}$, por 48 horas. A massa de conteúdo ruminal foi obtida somando-se os pesos das frações de sólidos e líquidos. O volume de líquidos foi estimado descontandose do peso total do conteúdo ruminal a massa de MS $(\mathrm{kg})$, assumindo uma densidade de $1,0 \mathrm{~kg} / \mathrm{L}$ para a fração líquida. A taxas de desaparecimento ( $\mathrm{ki}$, /h) da MS e FDN no rúmen foram calculadas de acordo com a seguinte equação (Rinne et al., 2002):

$$
\mathrm{ki}, / \mathrm{h}=\frac{1 / 24 \times(\text { consumo de MS ou FDN, } \mathrm{kg} / \mathrm{d})}{(\text { conteúdo ruminal de MS ou FDN, } \mathrm{kg})}
$$

As estimativas dos valores de enchimento da FDN, para cada tratamento, foram obtida através da regressão das massas de FDN no rúmen 
contra as massas de MS, nos dois horários de evacuação do conteúdo ruminal. Os coeficientes angulares da regressão, para cada tratamento, representaram os valores de enchimento da FDN e intervalos de confiança de $95 \%$ para estes coeficientes foram obtidos de acordo com a equação utilizada por Mooney \& Allen (1997).

As amostras das dietas completas, sobras e conteúdo ruminal, previamente seca em estufa a $65^{\circ} \mathrm{C}$ por 48 horas, foram moídas em moinho tipo Wiley com tela de 1,0 mm (Wiley Mill; Arthur H. Thomas, Philadelphia, PA). As amostras de dieta completa e sobras foram analisadas para determinação de MS, MM e PB (AOAC, 1990). As concentrações da FDN das dietas completas, sobras e conteúdo ruminal foram determindadas de acordo com Van Soest et al. (1991) utilizando solução de uréia $8 \mathrm{M}$ e amilase termoestável (Sigma A3306; Sigma Chemical Co., St. Louis, MO).

\subsubsection{Análise estatística}

O dados foram analisados utilizando o procedimento de modelos mistos (PROC MIXED) do pacote estatístico do SAS (1996) e de acordo com o seguinte modelo:

$$
Y i j k=\mu+V i+P j+T k+e i j k
$$

em que: Yijk , dado referente ao iésimo animal, do jésimo período, do k ésimo tratamento; $\mu$, média geral observada; $\mathrm{Vi}$, efeito aleatório do iésimo animal; Pj, efeito fixo jésimo período Tk, efeito fixo k-ésimo tratamento; e eijk, erro aleatório associado ao i-ésimo animal, do j-ésimo período do késimo tratamento. Os efeitos de tratamentos foram comparados através dos seguintes contrastes:

DBF vs. caroço de algodão: Avaliar a inclusão de $5 \%$ de FDN proveniente de caroço de algodão processado de várias formas em uma dieta basal com $16 \%$ de FDN proveniente de forragem (DBF $\times$ CA). 
DAF vs. caroço de algodão: Comparar a inclusão de $5 \%$ de FDN proveniente de caroço de algodão processado de várias formas, e adicionado uma dieta basal com $16 \%$ de FDN de forragem, àuma dieta com $21 \%$ de FDN proveniente de forragem (DAF $\times$ CA).

Caroço integral e tratado com amido vs. caroço sem linter: Avaliar a presença de linter no caroço (linter).

Caroço integral vs. Caroço tratado com amido: Avaliar o tratamento do caroço com 2,5\% de amido gelatinizado de milho (amido).

Caroço peletizado vs demais formas de processamento do caroço: Avaliar o tamanho de partículas do caroço de algodão (part.).

A consistência do "mat" ruminal e pH do fluído foram analisadas nos horários de coleta através da análise de medidas repetidas no tempo (REPEATED), com estrutura de convariância auto-regressiva de primeira ordem $[A R(1)]$, utilizando o procedimento de modelos mistos (PROC MIXED) do pacote estatístico do SAS (1996). Para rejeiçao ou aceitação no teste de hipóteses, foi utilizado nível de probabilidade de $5 \%(P<0,05)$ e as tedências foram discutidas no nível de probabilidade de 10\% $(\mathrm{P}<0,10)$. Quando as interações entre tratamento $x$ tempo não foram significativas $(P>0,10)$, a médias para todos horários de coleta foram apresentadas.

\subsection{RESULTADOS DE DISCUSSÃO}

\subsubsection{Composição química das dietas e forragens}

A composição química das dietas é apresentada na Tabela 12. As inclusões de resíduo de cervejaria e água nas dietas propiciaram teores de MS equivalentes entre os tratamentos, porém os valores foram ligeiramente inferiores ao objetivo inicial ( $50 \%$ de MS). O aumento da porcentagem de umidade foi utilizado como tentativa de evitar a seletividade de componentes das dietas pelas vacas. Esta medida não foi capaz de controlar completamente o problema, e foi necessário também adotar procedimentos padronizados para picagem das forragens, tempo de mistura das dietas e controle da porcentagem de sobras (2-3\% do oferecido). A importância da adição de água ou aumento no teor de umidade das dietas para reduzir seletividade de 
componentes foi demonstrada em um estudo anterior (Leonardi et al., 2002). Estes autores trabalharam com dois níveis de umidade $(35,7$ e 19,8\%, respectivamente) em dietas de vacas em lactação e verificaram que o aumento na porcentagem de umidade reduzia a seletividade.

Para concentração de PB ocorreram variações pequenas mas, em geral, os valores para todas as dietas foram próximos do teor $18 \%$ inicialmente proposto para o balanceamento das dietas (Tabela 12). De acordo com 0 balanceamento de dietas efetuado utilizando o NRC (2001), os balanços de proteína de degradável e não degradável no rúmen e protéina metabolizável foram positivos em todas as dietas.

As concentrações de FDN foram maiores do que o valor incialmente proposto para o balanceamento ( $31 \%$ da MS). Apesar das medidas adotadas para aumentar o teor de umidade das dietas e reduzir a seletividade, houve dificuldade para tomada de amostras das rações completas o que explica, em parte, a diferença entre teor programado e observado da FDN. A segregação de partículas durante a formação e manipulação das amostras compostas de rações completas foi o fator dificultou a obtenção de material representativo das dietas ofertadas.

Tabela 12. Composição química das dietas

\begin{tabular}{|c|c|c|c|c|c|c|}
\hline \multirow[b]{2}{*}{ Composição } & \multicolumn{6}{|c|}{ Caroço de algodão } \\
\hline & $\mathrm{DBF}^{1}$ & integral & amido & sem linter & peletizado & $\mathrm{DAF}^{1}$ \\
\hline$\overline{M S}, \%$ & 47,8 & 46,5 & 48,0 & 46,9 & 47,3 & 48,0 \\
\hline & & & & & & \\
\hline PB & 18,1 & 18,1 & 18,5 & 18,1 & 17,9 & 17,9 \\
\hline MO & 92,8 & 92,8 & 92,8 & 92,7 & 92,7 & 92,4 \\
\hline MM & 7,16 & 7,25 & 7,22 & 7,28 & 7,27 & 7,59 \\
\hline FDN & 36,3 & 35,8 & 33,1 & 32,7 & 35,8 & 32,2 \\
\hline
\end{tabular}

As porcentagens de MS e FDN das forragens utilizadas nos seis períodos experimentais estão na Tabela 13. Durante o experimento, foram utilizados três lotes diferentes de feno de alfafa que apresentou variação no 
teor de FDN maior do que a observada para o feno de gramínea. Considerando a variação observada na composição das forragens, foi necessário ajustar, durante o experimento, a porcentagem de volumosos das dietas para manter constante a proporção de FDNF, o que ocasionou variações na relação V:C. Considerando as análises de forragens realizadas durante a execução do experimento e a dietas ofertadas, as porcentagens médias de FDNF foram de $20,7 \%$ para dieta alta em forragem e $15,8 \%$ para as demais dietas, e estes valores foram próximos aos inicialmente programados $(21$ e $16 \%$, respectivamente).

Tabela 13. Composição química das forragens

\begin{tabular}{llcc}
\hline \multirow{2}{*}{ Forragem } & & \multicolumn{2}{c}{ Composição } \\
\hline Feno de alfafa & Média & 85,7 & FDN, \% da MS \\
& Amplitude & $80,7-88,1$ & 40,7 \\
Feno de gramínea & Média & 88,0 & $27,3-50,1$ \\
& Amplitude & $84,7-89,2$ & 63,4 \\
& &
\end{tabular}

\subsubsection{Consumo alimentar}

Os resultados para consumo de $\mathrm{MS}, \mathrm{MO}$ e $\mathrm{FDN}(\mathrm{kg} / \mathrm{d}$ e \% PV) são apresentados na Tabela 14. Os consumos de MS, MO e FDN foram menores ( $P<0,01$ ) nas dietas que incluiam FDN de caroço de algodão, quando comparadas à dieta com $16 \%$ de FDNF (DBF). Por outro lado, os consumos de MS, MO e FDN foram maiores ( $P<0,01$ ) quando quantidades equivalentes de FDN de caroço de algodão, processado de várias formas, substituiu parcialmente à FDNF. As formas de processamento do caroço de algodão não afetaram o consumo de MS, MO e FDN, porém o consumo de FDN expresso em porcentagem do $P V$ quando foi menor $(P=0,04)$ na dieta com caroço tratado com amido e tendeu $(P=0,08)$ à aumentar na dieta com caroço peletizado. As variações no consumo de FDN (\% do PV) foram associadas à concentrações 
Tabela 14. Consumo de vacas onde parte da forragem foi substituída por caroço de algodão processadas de várias formas.

\begin{tabular}{|c|c|c|c|c|c|c|c|c|c|c|c|c|c|}
\hline \multirow[b]{2}{*}{ Item } & \multicolumn{5}{|c|}{ Caroço de algodão } & & \multicolumn{2}{|c|}{$E P^{2}$} & \multicolumn{5}{|c|}{$P^{3,4}$} \\
\hline & $\mathrm{DBF}^{1}$ & integral & amido & sem linter & peletizado & $\mathrm{DAF}^{1}$ & $n=5$ & $\mathrm{n}=6$ & $\mathrm{DBF} \times \mathrm{CA}$ & DAF $\times$ CA & Linter & Amido & Part. \\
\hline $\mathrm{MS}, \mathrm{kg} / \mathrm{d}$ & 24,3 & 22,0 & 21,9 & 22,3 & $\overline{22,2}$ & 20,5 & 1,3 & 1,3 & $<0,01$ & $<0,01$ & NS & NS & NS \\
\hline $\mathrm{MO}, \mathrm{kg} / \mathrm{d}$ & 22,6 & 20,4 & 20,3 & 20,7 & 20,6 & 19,2 & 1,2 & 1,2 & $<0,01$ & 0,01 & NS & NS & NS \\
\hline FDN, $\mathrm{kg} / \mathrm{d}$ & 8,66 & 7,80 & 7,22 & 7,24 & 7,90 & 6,48 & 0,50 & 0,48 & $<0,01$ & $<0,01$ & NS & NS & NS \\
\hline MS, \% PV & 3,86 & 3,49 & 3,44 & 3,53 & 3,53 & 3,32 & 0,23 & 0,22 & $<0,01$ & $<0,01$ & NS & NS & NS \\
\hline MS, \% PV & 3,57 & 3,24 & 3,20 & 3,28 & 3,29 & 3,09 & 0,21 & 0,21 & $<0,01$ & $<0,01$ & NS & NS & NS \\
\hline FDN, \% PV & 1,37 & 1,25 & 1,13 & 1,14 & 1,26 & 1,04 & 0,09 & 0,08 & $<0,01$ & $<0,01$ & NS & 0,04 & 0,08 \\
\hline
\end{tabular}

$2 \mathrm{EP}=$ Erro padrão das médias. Para $\mathrm{DBF} n=5$ e para as demais $n=6$

${ }^{3}$ Probabilidade de resposta para tratamentos; $P<0,05=$ Significativa; $P<010=$ Tendências

${ }^{4}$ Contrastes testados: DBF X CA = comparar dietas com caroço de algodão processado de várias formas a uma dieta com $16 \%$ de FDNF; DAF X CA = = comparar dietas com caroço de algodão processado de várias formas a uma dieta com 16\% de FDNF; Linter = comparar de caroço de algodão integral e tratado com amido ao caroço sem linter; Amido = comparar caroço integral ao caroço tratado com amido; Part. = comparar caroço sem redução no tamanho de partículas (integral, amido e sem linter) ao caroço peletizado. 
desta fração nas dietas e provavelmente refletiram as dificuldades encontradas para coleta de amostras representativas das rações completas.

$O$ aumento no consumo de MS e FDN observado quando parte da FDNF forragem foi substituída por FDN de caroço de algodão também tem sido verificado em outras oportunidades (Clark \& Armentano, 1993; Harvatine et al., 2002a; Mooney \& Allen, 1997). Ao contrário do que foi verificado neste trabalho, Clark \& Armentano (1993) não observaram aumento no consumo de MS quando compararam uma dieta basal, com 13\% de FDNF, a uma dieta com $13 \%$ de FDNF e $6 \%$ de FDN de caroço de algodão. A ausência de efeito significativo da forma de processamento do caroço de algodão sobre o consumo de MS foi também verficada em outros trabalhos, quando as formas integral, tratado com amido, sem linter ou peletizado foram incluídas em 15\% na MS (Bernard et al., 1999; Bernard \& Amos, 1985; Firkins et al., 2002; Sullivan et al., 1993).

Considerando que as dietas foram formuladas com concentrações equivalentes de FDN, o consumo de MS menor, observado quando os tratamentos com caroço de algodão foram comparados ao tratamento com $16 \%$ de FDNF, pode ser explicado pelo aumento do enchimento ou repleção ruminal. Em médias, as dietas com caroço integral, tratado com amido e sem linter reduziram em $9,1 \%$ o consumo e aumentaram em $11,5 \%$ a massa de MS do conteúdo ruminal (Tabela 14).

\subsubsection{Produção e composição do leite}

A produção de leite e produção de leite corrigida foram maiores ( $P$ $<0,01$ ) no tratamento com $16 \%$ de FDNF (DBF), quando comparado aos tratamentos que incluiam caroço de algodão processadas de várias formas (Tabela 15). Neste caso, a diferença de produção de leite refletiu os resultados de consumo de MS e MO (Tabela 14), pois as concentrações de energia das dietas foram semelhantes 
Tabela 15. Produção e composição do leite de vacas onde parte da FDN forragem foi substituída por caroço de algodão processado de várias formas.

\begin{tabular}{|c|c|c|c|c|c|c|c|c|c|c|c|c|c|}
\hline \multirow[b]{2}{*}{ Item } & \multirow[b]{2}{*}{$\mathrm{DBF}^{1}$} & \multicolumn{4}{|c|}{ Caroço de algodão } & \multirow[b]{2}{*}{$\mathrm{DAF}^{1}$} & \multicolumn{2}{|c|}{$E P^{2}$} & \multicolumn{5}{|c|}{$P^{3,4}$} \\
\hline & & integral & amido & sem linter & peletizado & & $\mathrm{n}=5$ & $\mathrm{n}=6$ & DBF $\times$ CA & $\overline{D A F} \times \mathrm{CA}$ & Linter & Amido & Part. \\
\hline Leite, $\mathrm{kg} / \mathrm{d}$ & 37,9 & 34,2 & 32,3 & 31,5 & 32,5 & 32,7 & 2,7 & 2,6 & $<0,01$ & NS & NS & NS & NS \\
\hline Proteína, \% & 2,92 & 2,90 & 2,93 & 3,01 & 3,00 & 2,85 & 0,09 & 0,09 & $<0,01$ & $<0,01$ & 0,07 & NS & 0,04 \\
\hline Proteína, g/d & 1063 & 972 & 940 & 929 & 984 & 917 & 69 & 64 & 0,06 & NS & NS & NS & NS \\
\hline Gordura, \% & 3,60 & 3,80 & 3,84 & 3,81 & 3,63 & 3,89 & 0,29 & 0,26 & NS & NS & NS & NS & NS \\
\hline Gordura, g/d & 1363 & 1248 & 1223 & 1168 & 1151 & 1264 & 97 & 89 & 0,07 & NS & NS & NS & NS \\
\hline $\mathrm{NUL}, \mathrm{mg} / \mathrm{dl}^{5}$ & 15,7 & 16,7 & 17,9 & 17,8 & 17,5 & 15,8 & 0,90 & 0,80 & 0,01 & $<0,01$ & NS & NS & NS \\
\hline $\mathrm{PV}, \mathrm{kg}$ & 643 & 642 & 641 & 647 & 642 & 632 & 49 & 48 & NS & NS & NS & NS & NS \\
\hline
\end{tabular}

1 DAF = Dieta com $16 \%$ de FDNF; DAF = Dieta com $21 \%$ de FDNF

${ }_{3}^{3}$ Probabilidade de resposta para tratamentos; $P<0,05=$ Significativa; $P<010=$ Tendências.

${ }^{4}$ Contrastes testados: $\mathrm{DBF} \times \mathrm{CA}=$ comparar dietas com caroço de algodão processado de várias formas a uma dieta com $16 \%$ de FDNF; DAF $\times$ CA $==$ comparar dietas com caroço de algodão processado de várias formas a uma dieta com 16\% de FDNF; Linter = comparar de caroço de algodão integral e tratado com amido ao caroço sem linter; Amido = comparar caroço integral ao caroço tratado com amido; Part. = comparar caroço sem redução no tamanho de partículas (integral, amido e sem linter) ao caroço peletizado.

${ }^{5} \mathrm{NUL}=$ Nitrogênio uréico no leite 
As produções leite ou leite corrigida não diferiram quando as dietas com caroço de algodão foram comparadas entre si ou à dieta com $21 \%$ de FDNF. Em dois trabalhos anteriores, o consumo de MS e produção de leite aumentaram quando parte da FDNF foi substitituída por FDN de caroço de algodão (Clark \& Armentano, 1993; Mooney \& Allen, 1997), porém no trabalho de Harvatine et al. (2002a) a produção de leite não aumentou quando parte da FDNF foi substituída por caroço de algodão, apesar do consumo de MS ter mostrado resposta linear (aumento) a inclusão de caroço dieta.

Em outros trabalhos também a produção de leite, a produção de leite não foi afetada pelo tratamento das caroço de algodão com amido (Bernard, 1999; Bernard et al. 1999; Firkins et al., 2002). Por outro lado, Sullivan et al. (1993) observaram que a produção de leite foi menor na vacas que receberam caroço sem linter e Bernard \& Amos (1985) observaram a producão de leite aumentou quando o caroço peletizado foi comparado ao caroço integral. Nestes trabalhos, as vacas estavam em início de lactação (55 dias em lactação) e o processamento do caroço de algodão parece ter alterado a partição de nutrientes, pois não foram observados efeitos de tratamento sobre o consumo de MS.

Apesar das diferenças númericas, não houve efeito significativo de tratamento sobre a porcentagem de gordura no leite (Tabela 15). Devido ao efeito de tratamento sobre a produção de leite, houve tendência $(P=0,07)$ para produção maior de gordura na dieta com $16 \%$ de FDNF (DBF), quando comparada æ̀ di etas com caroço de algodão. Os resultados deste trabalho equipara-se ao de outros, onde a substituição parcial da FDNF por FDN de caroço de algodão também manteve o teor de gordura no leite (Clark \& Armentano, 1993; Harvatine et al., 2002a; Mooney \& Allen, 1997). Em geral, os efeitos do processamento do caroço da algodão sobre a porcentagem de gordura no leite têm sido variáveis. Bernard (1999) trabalhou com dietas de $22 \%$ de FDNF e não observou diferenças no teor de gordura no leite quando compararam caroço integral ao caroço tratado com amido. Por outro lado, 
Firkins et al.(2002) trabalharam com dietas de porcentagem baixa de forragem (15\% de FDNF) e observaram que o teor de gordura no leite da dieta com caroço tratado com amido foi menor do que na dieta com caroço integral.

Bernard \& Amos (1985) não observaram diferença na porcentagem de gordura no leite quando caroço de algodão integral ou peletizado foram incluidos em quantidades fixas nas rações de vacas em lactação $(2,72 \mathrm{~kg}$ de MS/d ou $12,3 \%$ da MS total). Já Sullivan et al.(1993) observaram que o teor de gordura no leite aumentou quando caroço sem linter substituiu caroço integral em dietas de vaca em lactação (3,40 vs. 3,$19 ; P<0,07)$.

A partir dos resultados de teor de gordura no leite apresentados na Tabela 15, foi possível concluir que o caroço de algodão tem efetividade de fibra semelhante à de forragens, quando a porcentagem de gordura no leite é utilizada como critério de avaliação. A efetividade baseada no teor de gordura no leite não foi afetada pela presença de linter ou pelo tamanho de particula do caroço de algodão.

A porcentagem de protéina no leite foi afetada pelos tratamentos (Tabela 15). Os tratamentos com caroço de algodão aumentaram $(P<0,01)$ a porcentagem de proteína, quando comparados aos tratamentos com 16 e $21 \%$ de FDNF. Como as comparações entre tratamentos foram efetuadas através de contrastes, este efeito foi atribuido as concentrações de proteína dos tratamentos com caroço sem linter e peletizado. A porcentagem menor de proteína no leite observada na dieta com 16\% FDNF refletiu a produção de leite maior neste tratamento o que, por efeito de diluição, provavelmente reduziu a concentração de proteína. Este mesmo efeito parece também ter ocorrido quando os tratamentos que incluiam caroço com linter foram comparados ao tratamento de caroço sem linter.

Clark \& Armentano (1993) também observaram que a porcentagem de proteína no leite aumentou quando compararam uma dieta com $6 \%$ de FDN de caroço integral e $13 \%$ de FDNF à um dieta com 19\% de FDNF. Harvatine et al.(2002a) observaram a porcentagem e produção de proteína aumentou 
linearmente quando trabalharam com três níveis de substibuição de FDNF por FDN de caroço de algodão integral (21, 18, 15 e 12\% de FDNF e 0, 3, 6 e 9\% de FDN de caroço). Segundo Clark \& Armentano (1993), dietas com porporção maior de FDNF fornecem aporte menor de energia fermentescível e energia total, o que contribui para reduzir a produção de leite e secreção de proteína.

Comparadas à dietas com 16 e $21 \%$ de FDNF, as dietas com caroço de algodão aumentaram ( $P=0,01$ e $P<0,01$, respectivamente) a concentração de nitrogênio uréico no leite (NUL) (Tabela 15). Estes resultados provavelmente refletem diferenças no aporte de energia fermentescível, consumo de proteína ou concentração de nitrogênio amoniacal no fluído ruminal, porém, nenhuma destas variáveis foram avaliadas neste experimento. Havartine et al (2002a) observaram respostas lineares nas concentrações de nitrogênio amoniacal no fluído ruminal e NUL quando trabalharam com três níveis de substituição de FDNF por FDN de caroço de algodão integral.

\subsection{4 pH e cinética ruminal}

$\mathrm{O} \mathrm{pH}$ médio do fluído ruminal foi maior $(\mathrm{p}=0,02)$ para o tratamento com $21 \%$ de FDNF, quando comparado aos tratamentos com caroço de algodão (Tabela 16). Nas demais comparações, não houve efeito de tratamentos sobre o pH médio do fluído ruminal (Tabela 16). A redução de $\mathrm{pH}$ observada nos tratamentos com caroço de algodão foi provavelmente relacionada a atividade de mastigação menor (Tabela 18) e consumo de MS digestível maior que, combinados, reduziram o fluxo de saliva e aumentaram a quantidade de substratos fermentescíveis presentes no rúmen. Harvatine et al. (2002a) também observaram redução linear no $\mathrm{pH}$ do fluído ruminal quando a FDNF foi substituida por FDN de caroço de algodão e atribuiram este efeito ao aumento no consumo de substrato fermentescível nas dietas que incluiam caroço de algodão. 
Tabela 16. Características da digesta ruminal de vacas onde parte da FDN forragem foi substituída por caroço de algodão processado de várias formas,

\begin{tabular}{|c|c|c|c|c|c|c|c|c|c|c|c|c|c|}
\hline \multirow[b]{2}{*}{ Item } & \multirow[b]{2}{*}{$\mathrm{DBF}^{1}$} & \multicolumn{4}{|c|}{ Caroço de algodão } & \multirow[b]{2}{*}{$\mathrm{DAF}^{1}$} & \multicolumn{2}{|c|}{$\mathrm{EP}^{2}$} & \multicolumn{5}{|c|}{$P^{3,4}$} \\
\hline & & integral & amido & sem linter & peletizado & & $n=5$ & $n=6$ & $\mathrm{DBF} \times \mathrm{CA}$ & $\mathrm{DAF} \times \mathrm{CA}$ & Linter & Amido & Part. \\
\hline$\overline{\mathrm{pH}}$ & 6,16 & 6,22 & 6,13 & 6,15 & 6,16 & 6,33 & 0,08 & 0,08 & NS & 0,02 & NS & NS & $\overline{\mathrm{NS}}$ \\
\hline \multicolumn{14}{|l|}{ Digesta ruminal } \\
\hline DM, \% & 13,2 & 14,3 & 13,8 & 13,8 & 13,4 & 12,2 & 0,5 & 0,5 & NS & $<0,01$ & NS & NS & NS \\
\hline NDF, \% DM & 58,6 & 57,2 & 59,9 & 60,0 & 58,4 & 56,6 & 1,7 & 1,6 & NS & NS & NS & NS & NS \\
\hline \multicolumn{14}{|l|}{ Digesta ruminal } \\
\hline Peso úmido, kg & 73,1 & 76,3 & 76,9 & 77,3 & 73,9 & 74,1 & 7,4 & 7,3 & NS & NS & NS & NS & NS \\
\hline MS, kg & 9,5 & 10,8 & 10,5 & 10,8 & 9,8 & 9,1 & 1,0 & 1,0 & NS & 0,01 & NS & NS & NS \\
\hline $\mathrm{MO}, \mathrm{kg}$ & 8,6 & 9,7 & 9,3 & 9,6 & 8,8 & 8,4 & 0,9 & 0,9 & NS & 0,06 & NS & NS & NS \\
\hline FDN, kg & 5,7 & 6,2 & 6,3 & 6,3 & 5,8 & 5,3 & 0,6 & 0,6 & NS & 0,01 & NS & NS & NS \\
\hline \multicolumn{14}{|l|}{$\mathrm{ki}, / \mathrm{h}$} \\
\hline MS & 0,109 & 0,088 & 0,089 & 0,091 & 0,094 & 0,099 & 0,005 & 0,004 & $<0,01$ & 0,03 & NS & NS & NS \\
\hline FDN & 0,067 & 0,056 & 0,049 & 0,049 & 0,058 & 0,057 & 0,004 & 0,004 & $<0,01$ & NS & NS & 0,10 & 0,03 \\
\hline \multicolumn{14}{|l|}{ Volume, L } \\
\hline Co-EDTA & 66,7 & 63,5 & 64,4 & 64,1 & 66,3 & 63,1 & 7,9 & 7,7 & NS & NS & NS & NS & NS \\
\hline Esvaziamento & 62,9 & 64,8 & 65,7 & 65,9 & 63,4 & 64,4 & 6,4 & 6,3 & NS & NS & NS & NS & NS \\
\hline kp fluídos, /h & 0,145 & 0,155 & 0,144 & 0,144 & 0,144 & 0,158 & 0,12 & 0,12 & NS & NS & NS & NS & NS \\
\hline
\end{tabular}


Os resultados para porcentagem de MS e FDN da digesta ruminal são apresentados na Tabela 16. A porcentagem de MS da digesta ruminal foi maior $(P=0,01)$ nos tratamentos com caroço de algodão, quando comparados ao tratamento com $21 \%$ de FDNF (Tabela 14). Para demais comparações, não houve efeito de tratamentos sobre a porcentagem de MS da digesta ruminal (Tabela 16). As porcentagens de FDN da digesta ruminal não foram afetadas pelos tratamentos (Tabela 16). Havartine et al.(2002b) observaram que as porcentagens de MS e FDN da digesta ruminal aumentaram linearmente quando trabalharam com três níveis de substituição da FDNF por FDN de caroço de algodão.

A dieta com $21 \%$ de FDNF diminuiu as massas $(\mathrm{kg})$ de $M S$ ( $P=0,01)$, $M O$ $(P=0,06)$ e FDN $(P=0,01)$ no rúmen quando comparada æ̀ dietas com caroço de algodão (Tabela 16). Estes resultados foram provavelmente relacionados à atividade maior de mastigação observada neste tratamento (Tabela 18), conforme será discutido posteriormente. Ao aumentar à atividade de mastigação, vacas em lactação podem alterar as taxas de digestão e passagem e, desta forma, compensar o valor de enchimento maior de determinadas dietas (Dado \& Allen, 1995).

As taxas de desaparecimento ( $\mathrm{ki}$ ) da MS foram maiores nos tratamentos que não incluiam caroço de algodão e as taxas de desaparecimento da FDN foram afetadas tanto pela inclusão quanto pela forma de processamento do caroço de algodão (Tabela 16). Não foi possível concluir se estes resultados foram devidos à alterações nas taxas de digestão $(\mathrm{kd})$ ou passagem $(\mathrm{kp})$, pois somadas estas taxas compõem a taxa de desaparecimento. Exceto na dieta com $21 \%$ de FDNF, a casca de soja foi utilizada, em diferentes teores, para ajustar as concentrações de FDN das dietas (Tabela 11), porém, a porcentagem maior de casca de soja foi utilizada na dieta com $16 \%$ de FDNF (7,78 \% da MS). A casca de soja e caroço de algodão diferem no tamanho de partícula e na taxa de digestão da FDN, e provavelmente estes fatores foram responsáveis pelas diferenças observadas nas taxas de desaparecimento da 
MS e FDN. Bhatti \& Firkins (1995) verificaram que a casca de soja apresentavam um taxa de digestão de FDN maior (0,0332 vs. 0,0208/h) e um tempo de colonização menor (5,7 vs. 14,7 horas) do que a casca de algodão.

A taxa maior de desaparecimento da MS para o tratamento com $21 \%$ de FDNF, quando comparado aos tratamentos que incluiam caroço de algodão, foi provavelmente ocasionada pela atividade de mastigação maior pois, conforme discutido anteriormente, ao aumentar àatividade de mastigação, o animal pode alterar as taxas de digestão e passagem da digesta pelo rúmen(Dado \& Allen, 1995).

A redução na taxa de desaparecimento da FDN observada para o tratamento com caroço tratado com amido foi ocasionada pelo consumo menor de FDN neste tratamento, pois as massas de MS e FDN na digesta ruminal e consumo de MS não diferiram entre os tratamentos com caroço de algodão integral ou tratado com amido. O aumento na taxa de desaparecimento da FDN para o tratamento com caroço peletizado confirmou a importância do tamanho de partículas para retenção do caroço de algodão no rúmen.

O volume de ruminal (L) não foi afetado pelos tratamentos e os valores calculados atráves da dilução do Co-EDTA ou evacuação do conteúdo ruminal foram semehantes (Tabela 16). A boa distribuição do Co-EDTA na digesta ruminal após a dosagem e os procedimentos de coleta de amostras do conteúdo ruminal são fatores que contribuem para acurácia destas determinações (Harvatine et al., 2002b) e podem ter contribuído para os resultados alcançados.

Através das estimativas obtidas para o valor de enchimento da FDN, nos diferentes tratamentos, foi possível verificar que a dieta com $21 \%$ de FDNF e as dietas com caroço de algodão integral ou tratado com amido apresentaram coeficientes numericamente equivalentes e mais elevados do que as demais dietas (Tabela 17). Por meio desta comparações, foi possível também verificar que os coeficientes obtidos para as caroço sem linter ou peletizado foram numericamente inferiores ao do caroço integral ou tratado com amido. Neste 
caso, a redução no valor de enchimento sugere que e a integridade do caroço e a presença de linter foram fatores determinantes do valor de enchimento. Vale ressaltar que as diferenças foram apenas numéricas e desta forma, os resultados devem ser interpretados com cautela pois os intervalos confiança calculados para cada tratamento sugerem que os valores de enchimento podem ser equivalentes.

Tabela 17. Coeficiente de enchimento da FDN quando parte da forragem foi substituída por caroço de algodão processado de várias formas.

\begin{tabular}{lcccc}
\hline & \multirow{2}{*}{$\begin{array}{c}\text { Coeficiente } \\
\text { Dieta }\end{array}$} & $\mathrm{kg}$ de FDN/kg de MS & $\mathrm{EP}^{1}$ & \multicolumn{2}{c}{ Amplitude } \\
\cline { 5 - 5 } $16 \%$ de FDNF & 0,46 & 0,12 & 0,21 & Máximo \\
$21 \%$ de FDNF & 0,58 & 0,14 & 0,28 & 0,85 \\
Caroço de algodão & & & & \\
Integrais & 0,59 & 0,12 & 0,32 & 0,85 \\
Tratadas com amido & 0,59 & 0,08 & 0,40 & 0,78 \\
Sem linter & 0,49 & 0,08 & 0,30 & 0,67 \\
Peletizadas & 0,36 & 0,08 & 0,18 & 0,54
\end{tabular}

${ }^{\top}$ Erro padrão para o coefieciente angular.

\subsubsection{Comportamento ingestivo}

O tempo total de ingestão $(\mathrm{min} / \mathrm{d})$ não foi afetado pelos tratamentos, porém os tempos totais de ruminação e mastigação foram menores para os tratamentos com caroço de algodão, quanto comparados ao tratamento com 21\% FDNF (Tabela 18). Quando expressos por unidade de MS ou FDN consumida $(\mathrm{kg} / \mathrm{d})$, os tempos de ingestão, ruminação e mastigação foram maiores $(P<0,05)$ para o tratamento com $21 \%$ de FDNF e menores $(P<0,03)$ para o tratamento com $16 \%$ FDNF, quando comparados aos tratamentos com caroço de algodão. A partir destes resultados foi possível concluir que, os coeficientes de efetividade física (FDNfe) da FDN do caroço de algodão, independente da forma de processamento, foram inferiores ao de forragem. As efitividades físicas da FDN (FDNfe) calculadas a partir da atividade de 
Tabela 18. Atividade de mastigação de vacas onde parte da FDN da forragem foi substituída por caroço de algodão processadas de várias formas.

\begin{tabular}{|c|c|c|c|c|c|c|c|c|c|c|c|c|c|}
\hline \multirow[b]{2}{*}{ Item } & \multirow[b]{2}{*}{$\mathrm{DBF}^{1}$} & \multicolumn{4}{|c|}{ Caroço de algodão } & \multirow[b]{2}{*}{$\mathrm{DAF}^{1}$} & \multicolumn{2}{|c|}{$E P^{2}$} & \multicolumn{5}{|c|}{$P^{3,4}$} \\
\hline & & integrais & amido & sem linter & Peletizado & & $\mathrm{n}=5$ & $n=6$ & DBF $\times$ CA & DAF $\times$ CA & Linter & Amido & Part. \\
\hline \multicolumn{14}{|l|}{ Ingestão } \\
\hline $\min / \mathrm{d}$ & 288 & 288 & 287 & 307 & 281 & 304 & 12 & 11 & NS & NS & NS & NS & NS \\
\hline $\mathrm{min} / \mathrm{kg}$ de MS & 11,8 & 13,5 & 13,2 & 13,9 & 12,8 & 15,2 & 0,9 & 0,9 & 0,02 & $<0,01$ & NS & NS & NS \\
\hline $\mathrm{min} / \mathrm{kg}$ de FDN & 33,6 & 37,4 & 40,4 & 43,2 & 37,2 & 48,6 & 3,3 & 3,1 & 0,03 & $<0,01$ & NS & NS & NS \\
\hline \multicolumn{14}{|l|}{ Ruminação } \\
\hline $\min / \mathrm{d}$ & 427 & 420 & 426 & 441 & 420 & 476 & 33 & 30 & NS & 0,05 & NS & NS & NS \\
\hline $\mathrm{min} / \mathrm{kg}$ de MS & 17,6 & 19,4 & 19,9 & 20,1 & 19,1 & 23,8 & 2,0 & 1,9 & NS & $<0,01$ & NS & NS & NS \\
\hline $\mathrm{min} / \mathrm{kg}$ de FDN & 49,5 & 54,0 & 61,3 & 63,1 & 54,1 & 76,1 & 6,3 & 6,0 & 0,07 & $<0,01$ & NS & NS & NS \\
\hline \multicolumn{14}{|l|}{ Mastigação } \\
\hline $\min / \mathrm{d}$ & 710 & 708 & 713 & 748 & 701 & 780 & 37 & 35 & NS & 0,02 & NS & NS & NS \\
\hline $\mathrm{min} / \mathrm{kg}$ de MS & 29,4 & 32,8 & 33,0 & 34,0 & 31,9 & 39,0 & 2,8 & 2,7 & 0,03 & $<0,01$ & NS & NS & NS \\
\hline $\mathrm{min} / \mathrm{kg}$ de FDN & 83 & 91 & 101 & 106 & 90 & 124 & 9 & 9 & 0,03 & $<0,01$ & NS & NS & NS \\
\hline
\end{tabular}

${ }^{1}$ DAF = Dieta com $16 \%$ de FDNF; DAF = Dieta com $21 \%$ de FDNF

${ }^{3}$ Probabilidade de resposta para tratamentos; $P<0,05=$ Significativa; $P<010=$ Tendências.

${ }^{4}$ Contrastes testados: DBF $\times$ CA = comparar dietas com caroço de algodão processado de várias formas a uma dieta com $16 \%$ de FDNF; DAF X CA = = comparar dietas com caroço de algodão processado de várias formas a uma dieta com 16\% de FDNF; Linter = comparar de caroço de algodão integral e tratado com amido ao caroço sem linter; Amido = comparar caroço integral ao caroço tratado com amido; Part. = comparar caroço sem redução no tamanho de partículas (integral, amido e sem linter) ao caroço peletizado. 
mastigação, foram de 0,$46 ; 0,44 ; 0,71$ e 0,28 ; respectivamente, para o caroço integral, tratado com amido, sem linter e peletizado. A partir do erro padrão destas estimativas $( \pm 0,29)$, foi também possível concluir que as efetividades da FDN de caroço de algodão não foram afetadas pela forma de processamento do caroço.

Clark \& Armentano (1993) não observaram diferenças na atividade de mastigação quando uma dieta com 13,3\% de FDNF (feno de alfafa) e 5,7\% de FDN de caroço de algodão foi comparada àuma dieta com $18,8 \%$ de FDNF de feno de alfafa. Caso a metodologia proposta por Mooney \& Allen (1997) fosse utilizada para calcular a efetividade da FDN do caroço de algodão neste trabalho, a efetividade calculada seria de $91 \%(0,91)$.

A efetividade da FDN do caroço de algodão depende do tamanho de partícula da forragem utilizada com referência. Mooney \& Allen (1995) observaram que, dependendo do tamanho de partícula da forragem, o caroço de algodão aumenta ou diminuia a atividade de mastigação. Neste caso, os coeficientes de efetividade da FDN foram de $127(1,27)$ e $50 \%(0,50)$ para caroço comparado ao feno com tamanho de partículas de 5,8 e 11,4 mm, respectivamente.

Havartine et al.(2002b) trabalharam com a silagem de alfafa com tamanho médio de partículas de 5,6 $\mathrm{mm}$ e encontram uma efetividade de $84 \%$ para a FDN do caroço de algodão. Considerando o erro padrão obtido para esta estimativa, os autores concluíram que efetividade da FDN do caroço de algodão não diferiu significativamente da efetividade da FDN da silagem de alfafa.

\subsubsection{Consistência do "mat" ruminal}

A consistência do "mat" ruminal não foi afetada pelos tratamentos (Tabela 19). Harvatine et al.(2002b) também não observaram diferenças para consistência do "mat" e atribuíram os resultados ao aumento da massa de MS 
e FDN na digesta ruminal quando substituíram progressivamente a FDNF por FDN de caroço de algodão. As massas de MS e FDN no conteúdo ruminal foram maiores para os tratamentos com caroço de algodão (Tabela 16), quando comparados ao tratamento com $21 \%$ de FDNF. Assim, os resultados de consistência do "mat" ruminal para este experimento também podem ser explicados por variações nas massas de MS e FDN na digesta ruminal. Segundo Harvatine et al. (2002b), o aumento na massa de MS na digesta ruminal estimularia receptores de tensão ou provocariam estimulação táctil suficiente na parede do rúmen para manter a atividade de mastigação em nível comparável ao de dietas com proporção maior de FDNF. Como não houve efeito de tratamento, foi possível concluir que a consistência do "mat" não foi afetada pela presença de linter ou pelo tamanho de partícula do caroço de algodão.

Table 19. Consistência da camada flutuante do rúmen (mat) de vacas onde parte da forragem foi substituída por caroço de algodão processadas de várias formas.

\begin{tabular}{|c|c|c|c|c|c|c|c|c|}
\hline \multirow[b]{2}{*}{ Item } & \multirow[b]{2}{*}{$\mathrm{DBF}^{1}$} & \multicolumn{4}{|c|}{ Caroço de algodão } & \multirow[b]{2}{*}{$\mathrm{DAF}^{1}$} & \multicolumn{2}{|c|}{$E P^{2}$} \\
\hline & & integral & amido & sem linter & peletizado & & $\mathrm{n}=5$ & $\mathrm{n}=6$ \\
\hline \multicolumn{9}{|c|}{ Distância, cm } \\
\hline $1 \mathrm{~min}$ & 8,6 & 9,7 & 10,9 & 9,9 & 12,7 & 9,0 & 1,6 & 1,4 \\
\hline $2 \min$ & 13,7 & 13,9 & 16,5 & 14,6 & 18,9 & 14,3 & 2,3 & 2,1 \\
\hline $5 \mathrm{~min}$ & 22,9 & 22,6 & 24,8 & 23,1 & 27,3 & 25,2 & 3,2 & 2,8 \\
\hline $9 \mathrm{~min}$ & 29,5 & 28,1 & 29,9 & 29,1 & 33,9 & 35,0 & 3,6 & 3,2 \\
\hline \multicolumn{9}{|c|}{ Tx. ascensão, cm/s } \\
\hline $1 \mathrm{~min}$ & 0,15 & 0,16 & 0,17 & 0,16 & 0,21 & 0,15 & 0,03 & 0,02 \\
\hline $2 \mathrm{~min}$ & 0,12 & 0,12 & 0,13 & 0,12 & 0,16 & 0,12 & 0,02 & 0,02 \\
\hline $5 \mathrm{~min}$ & 0,080 & 0,075 & 0,079 & 0,077 & 0,091 & 0,081 & 0,010 & 0,009 \\
\hline $9 \mathrm{~min}$ & 0,055 & 0,052 & 0,055 & 0,054 & 0,063 & 0,065 & 0,006 & 0,006 \\
\hline
\end{tabular}

DAF = Dieta com $16 \%$ de FDNF; DAF = Dieta com $21 \%$ de FDNF

${ }^{2} \mathrm{EP}=$ Erro padrão para as médias. Para $\mathrm{DBF} n=5$ e para as demais $n=6$.

Em outros estudos a consistência do "mat" foi reduzida quando de subprodutos substituíram parcialmente a FDNF (Allen \& Grant, 2000; .Weidmer \& Grant, 1994b). A redução na consitência do "mat" observada nestes estudos provavelmente foi responsável pela atividade de mastigação menor verificada 
para os tratamentos que incluiam os subprodutos. Estes resultados também suportam a hipótese que o caroço de algodão apresenta efetividade da fibra diferenciada de outros subprodutos.

\subsection{CONCLUSÕES}

A porcentagem de gordura no leite, a atividade de mastigação, a consistência do "mat" e a cinética ruminal não foram afetadas pela forma de processamento do caroço de algodão. Assim, além da presença de linter e tamanho de partícula, outros fatores são também afetam pela efetividade da fibra do caroço de algodão.

A porcentagem de gordura no leite não diferiu entre as dietas que incluiam FDN de caroço de algodão e a dieta com $22 \%$ de FDNF, porém a atividade de mastigação foi menor nas dietas que incluiam FDN de caroço, sugerindo que a FDNfe do caroço de algodão foi inferior a da forragem.

As massas de MS e FDN na digesta ruminal foram maiores e a consistência do "mat" não diferiu quando dietas com caroço de algodão foram comparadas à dieta com $21 \%$ de FDNF, sugerindo que as respostas observadas na atividade de mastigação para este subproduto foram relacionadas à alterações na cinética de digestão e passagem da digesta pelo rúmen. 


\section{CONCLUSÕES GERAIS}

Apesar das variações observadas no tamanho de partículas e composição da FDN entre as forragens, não ocorreram diferenças nas atividade de mastigação ou teor de gordura no leite, sugerindo que as forragens estudadas apresentaram efetividades da fibra equivalentes. As respostas obtidas para estas variáveis podem ter sido limitadas pela substituição apenas parcial da FDN da silagem de milho por outras forragens.

A partir dos resultados de composição do leite, comportamento ingestivo e cinética ruminal conclui-se que, além da presença de linter e tamanho de partícula, outros fatores também afetam a efetividade da FDN do caroço de algodão. As respostas observadas na atividade de mastigação com a inclusão caroço de algodão nas dietas foram determinadas por alterações na cinética de digestão e passagem da digesta pelo rúmen 


\section{REFERÊNCIAS BIBLIOGRÁFICAS}

ALLEN, M.S. Physical constraints on voluntary intake of forages by ruminants. Journal of Animal Science, v.74, p.3063-3075, 1996.

ALLEN, M.S. Relationship between fermentation acid production in the rumen and the requirement for physically effective fiber. Journal of Dairy Science, v.80, p.1447-1462, 1997.

ALLEN, M.S. Effects of diet on short-term regulation of feed intake by lactating dairy cattle. Journal of Dairy Science, v.83, p.1598-1624, 2000.

ALLEN, D.M.; GRANT, R.J. Interactions between forage and wet corn gluten feed as sources of fiber in diets for lactating dairy cows. Journal of Dairy Science, v.83, p.322-331, 2000.

ALVES, J.B.; GODOY, M.M. de; BERGAMASCHINE, BASTOS, J.F.P. Digestibilidade da cana hidrolisada e in natura In: REUNIÃO ANUAL DA SOCIEDADE BRASILEIRA DE ZOOTECNIA, 37; Piracicaba, 2001. Anais. Viçosa:SBZ, 2001.

ARMENTANO, L.; PEREIRA, M. Measuring the effectiveness of fiber by animal response trials. Journal of Dairy Science, v.80, p.1416-1425, 1997. 
ASSOCIATION OF OFFICIAL ANALYTIC CHEMISTS INTERNATIONAL. Official methods of analysis. 15. ed. Arlington, 1990. 473p.

BAL, M.A.; SHAVER, R.D.; JIROVEC, A.G.; SHINNERS, K.J.; COORS, J.G. Crop processing and chop length of corn silage: Effects on intake, digestion, and milk production by dairy cows. Journal of Dairy Science, v.83, p.12641273, 2000.

BEAUCHEMIN, K.A. Effects of dietary neutral detergent fiber concentration and supplementary long hay on chewing activities and milk production of dairy cows. Journal of Dairy Science, v.72, p. 2288-2300, 1989.

BEAUCHEMIN, K.A.; BUCHANAN-SMITH, J.G. Effects of dietary neutral detergent fiber concentration and alfalfa hay quality on chewing, rumen function, and milk production of dairy cows. Journal of Dairy Science, v.72, p. 3140-3151, 1991.

BERCHIELLI. T.T.; ANDRADE, P.; FURLAN, C.L. Avaliação de indicadores internos em ensaios de digestibilidade. Revista Brasileira de Zootecnia. v. 29 , p. $830-833,2000$.

BERGER, L.; KLOPFENSTEIN, T.; BRITTON, R. Effect of sodium hydroxide on efficiency of rumen digestion. Journal of Animal Science, v.49, p. 13171323, 1979.

BERNARD, J.K. Performance of lactating dairy cows fed whole cottonseed coated with gelatinized cornstarch. Journal of Dairy Science, v.82, p.13051309, 1999. 
BERNARD, J.K.; AMOS, H.E. Influence of pelleting whole cottonseed on ration digestibility and milk production and composition. Journal of Dairy Science, v.68, p.3255-3261, 1985.

BERNARD, J.K.; CALHOUN, M.C.; MARTIN, S.A. Effect of coating whole cottonseed on performance of lactating dairy cows. Journal of Dairy Science, v.82, p.1296-1304, 1999.

BHATTI, S.A; FIRKINS, J.L. Kinetics of hydration and functional specific gravity of fibrous feed by-products. Journal of Animal Science, v.73, p. 1449-1458, 1995.

BOIN, C.; ALLEONI, G.F., BIONDI, P.; BONILHA NETO, L.M. Comparação entre silagem de milho e cana-de-açúcar na alimentação de ruminantes. 1. Efeito do nível de concentrado na produção de leite. In: REUNIÃO ANUAL DA SOCIEDADE BRASILEIRA DE ZOOTECNIA, 20; Pelotas, 1983, Anais. Viçosa:SBZ, 1983a.

BOIN, C.; ALLEONI, G.F., BIONDI, P.; BEISMAN, D. BONILHA NETO, L.M. Comparação entre silagem de milho e cana-de-açúcar na alimentação de ruminantes. 2. Efeito da suplementação com uréia na produção de leite. In: REUNIÃO ANUAL DA SOCIEDADE BRASILEIRA DE ZOOTECNIA, 20; Pelotas, 1983, Anais. Viçosa:SBZ, 1983b.

BOWMAN, J.G.P.; HUNT, C.W.; KERLEY, M.S.; PATERSON, J.A. Effects of grass maturity and legume substituition on large particle size reduction and small particle flow from the rumen of cattle. Journal of Animal Science, v.69, p.369-378, 1991. 
BUCKMASTER, D.R. Particle size in dairy ration In: GARNSWORTHY, P.C.; WISEMAN, J. (Ed.) Recent Advances in Animal Nutrition. Nottingham: Nottingham University Press, 2000, cap. 8, p.109-128.

CAMPOS, F.P.; SAMPAIO, A.A.M.; VIEIRA, P.F.; BOSE, M.L.V. Digestibilidade in vitro/gás de volumosos exclusivos ou combinados avaliados pelo resíduo remanescente da digestão da matéria seca e produção de gás. Revista Brasileira de Zootecnia. v. 30, p. 1579-1589, 2001.

CHESSON, A. Mechanistic models of forage cell wall degradation. In: JUNG, H.G., BUXTON, D.R.; HATFIELD, R.D.; RALPH, J. (Ed.) Forage cell wall structure and digestibility, Madison: ASA, CSSA, SSSA, 1993. cap. 14, p. 347-376.

CLARK, P.W.; ARMENTANO, L.E. Influence of particle size on the effectiveness of the fiber in corn silage. Journal of Dairy Science, v.82, p.581-588, 1999.

CLARK, P.W.; ARMENTANO, L.E. Replacement of alfalfa neutral detergent fiber with a combination of nonforage fiber sources. Journal of Dairy Science, v.80, p.675-680, 1997.

CLARK, P.W.; ARMENTANO, L.E. Effectiveness of neutral detergent fiber in whole cottonseed and dried distillers grains compared with alfafa haylage. Journal of Dairy Science, v.76, p.2644-2650, 1993.

CASSIDA, K.A.; STOKES, Eating and resting salivation in early lactation dairy cows Journal of Dairy Science, v. 69, p. 1282-1292, 1986. 
COLENBRANDER, V.F.; NOLLER, C.H.; GRANT, R.J. Effect of fiber content and particle size of alfalfa silage on performance and chewing behavior. Journal of Dairy Science, v. 74, p. 2681-2681, 1991.

COPPOCK, C.E.; MOYA, J.R.; WEST, J.W.; NAVE, D.H.; LABORE, J.M.; GATES, C.E. Effect of lint on whole cottonseed passage and digestibility and diet choice on intake of whole cottonseed. Journal of Dairy Science, v.68, p. 1198-1026, 1985.

CORREA, C.E.S.; PEREIRA, M.N.; RAMOS, M.H.; OLIVEIRA, S.G.; OTA, M. Performance of dairy cows fed corn silage differing in kernel texture or sugarcane as the dietary forage. . Journal of Dairy Science, v. 83, Suppl. 1, 2000.

CORNELL-PEN-MINOR Dairy Cornell-Pen-Minor: A program to formulate rations for diary cattle Version 1.0 University of Pensylvannia, Kennett Square, PA: Williams, H.Minor Ag. Res. Institute, Chazy, NY and Cornell University, Ithaca, NY. 1998.

CUNNINGHAM, K.D.; CECAVA, M.J.; JOHNSON, T.R. Nutrient digestion, nitrogen, and amino acids flows in lactating cows fed soybean hulls in place of forage or concentrate. . Journal of Dairy Science, v. 76, p. 3523-3535, 1993

DADO, R.G.; ALLEN, M.S. Intake limitations, feeding behavior, and rumen function of cows challenged with rumen fill from dietary fiber on inert bulk. Journal of Dairy Science, v.78, p.118-133, 1995. 
DE BOEVER, J.L.; DE SMET, A.; BRABANDER, D.L., BOUCQUE, C.V. Evaluation of physical struture. 1. Grass silage. Journal of Dairy Science, v. 76, p. $140-153,1993 a$

DE BOEVER, J.L.; DE SMET, A.; BRABANDER, D.L., BOUCQUE, C.V. Evaluation of physical struture. 2. Corn silage. Journal of Dairy Science, v. 76, p. $1624-1634,1993 b$

DEPIES, K.K.; ARMENTANO, L. Partial replacement of alfalfa fiber with fiber from ground corn cobs or wheat middlings. Journal of Dairy Science, v.78, p.1328-1335, 1995

ERDMAN, R.A.; Dietary buffering requirements of the lactating dairy cow: a review. Journal of Dairy Science, v.71, p.3246-3266, 1988.

ERWIN, W.S.; MARCO, G.J.; EMERY, E.M. Volatile fatty acids analyses of blood and rumen fluid by gas chromatography. Journal of Dairy Science, v.44, p.1768-1771, 1961.

EZEQUIEL, J.M.B.; GASTALDI, K.A.; QUEIROZ, M.A.A. Efeitos da hidrólise alcalina nos teores de carboidratos solúveis, matéria seca, matéria orgânica e matéria mineral da cana-de-açúcar. In: REUNIÃO ANUAL DA SOCIEDADE BRASILEIRA DE ZOOTECNIA, 37; Piracicaba, 2001.Anais. Viçosa:SBZ, 2001b. 
EZEQUIEL, J.M.B.; GALATI, R.L.; GASTALDI, K.A.; QUEIROZ, M.A.A.; MENDES, A.R.; FEITOSA, J.V. Degradabilidade da matéria seca e pH ruminal em bovinos alimentados com cana-de-açúcar in natura, hidrolisada ou hidrolisada fenada. In: REUNIÃO ANUAL DA SOCIEDADE BRASILEIRA DE ZOOTECNIA, 37; Piracicaba, 2001. Anais. Viçosa:SBZ, 2001c. P.277279.

EZEQUIEL, J.M.B.; GALATI, R.L.; GASTALDI, K.A.; QUEIROZ, M.A.A.; MENDES, A.R.; FEITOSA, J.V. Degradabilidade da matéria seca e pH ruminal de bovinos alimentados com cana-de-açúcar in natura,hidrolisada ou hidrolisada fenada. In: REUNIÃO ANUAL DA SOCIEDADE BRASILEIRA DE ZOOTECNIA, 37; Piracicaba, 2001. Anais. Viçosa:SBZ, 2001c. P.321-323.

FAICHNEY, G.J. The use of markers to partition digestion within the gastrointestinal tract of ruminants. In: International Symposium on Ruminant Physiology, 4; Armidale,1975. Proceedings. Armidale: University of New England, 1975, p. 277-291.

FIRKINS, J.L. Fiber value of alternative feeds. In: National Alternative Feeds Syposium, Columbia, 1995, Proceedings. Columbia: Eastridge, M.L., 1995, p. 221-231.

FIRKINS, J.L. Effects of feeding nonforage fiber sources on site of fiber digestion. Journal of Dairy Science, v.80, p.1426-1437, 1997.

FIRKINS, J.L.; ALLEN, M.S.; OLDICK, B.S.; ST-PIERRE, N.R. Modeling ruminal digestibility of carbohydrates and microbial protein flow to the duodenum. Journal of Dairy Science, v.81, p.3350-3369, 1998. 
FIRKINS, J.L. Optimizing rumen fermentation. In: Tri-State Dairy Nutrition Conference, Fort Wayne, 2002. Proceedings . Fort Wayne: Eastridge, M.L., 2002, p. 39-54.

FIRKINS, J.L.; HARVATINE, D.I.; SYLVESTER, J.T.; EASTRIDGE, M.L. Lactation performance by dairy cows fed wet brewers grains or whole cottonseed to replace forage. Journal of Dairy Science, v.85, p.2662-2668, 2002.

GAYNOR, P.J.; WALDO, D.R.; CAPUCO, A.V.; ERDMAN, R.A.; DOUGLASS, L.W.; TETER, B.B. Milk fat depression the glucogenic theory, and transC18:1 fatty acids. Journal of Dairy Science, v.78, p.2008-2015, 1995

GRANT, R.J. Interactions among forages and nonforage fiber sources. Journal of Dairy Science, v.80, p.1438-1446, 1997.

GRANT, R.J.; MERTENS, D.R. Influence of buffer $\mathrm{pH}$ and raw corn starch addition on in vitro fiber digestion kinetics. Journal of Dairy Science, v.75, p. 2762-2768, 1992.

GRANT, R.J. COLENBRANDER, V.F.; MERTENS, D.R. Milk fat depression in dairy cows: Role of particle size of alfalfa hay. Journal of Dairy Science, v.73, p.1823-1833, 1990a.

GRANT, R.J. COLENBRANDER, V.F.; MERTENS, D.R. Milk fat depression in dairy cows: Role of silage particle size. Journal of Dairy Science, v.73, p.1438-1446, 1990b. 
HARMISON, B.; EASTRIDGE, M.L.; FIRKINS, J.L. Effect of percentage of dietary forage neutral detergent fiber and source of starch on performance of lactating Jersey cows. . Journal of Dairy Science, v.80, p. 905-911, 1997.

HARVATINE, D.I.; FIRKINS, J.L.; EASTRIDGE, M.L. Whole linted cottonseed as a forage substitute fed with ground or steam-flaked corn: Digestibility and performance. Journal of Dairy Science, v.85, p. 1976-1987, 2002a.

HARVATINE, D.I.; FIRKINS, J.L.; EASTRIDGE, M.L. Whole linted cottonseed as a forage substitute fed with ground or steam-flaked corn:Fiber effectiveness and digestion kinetics. Journal of Dairy Science, v.85, p. 1988-1999, 2002b.

HEINRICHS, A.J.; LAMMERS, B.P. Particle size recommendations for dairy cattle. In: Silage: Field to Feedbunk. Hershey, Pennsylvania, 1997. Proceedings. Ithaca, NY,: Northeast Regional Agricultural Engineering Service, 1997. p. 268-277.

KALSCHEUR, K.F., TETER, B.B.; PIPEROVA, L;.S.; ERDMAN. Effect of dietary forage concentration and buffer addition on duodenal flow of trans-C18:1 fatty acids and milk fat production in dairy cows. Journal of Dairy Science, v.80, p. 2104-2114, 1997.

KLOPFENSTEIN, T.; OWEN, F.G. Value and potencial use of crop residues and by-products in dairy rations Journal of Animal Science, v.64, p. 12501268, 1981.

LAMMERS, B.P.; BUCKMASTER, D.R.; HEINRICHS, A.J. A simple method for the analysis of particle sizes of forage and total mixed rations. Journal of Dairy Science, v.79, p. 922-928, 1996. 
LEONARDI, C.; GIANNICO, F.; ARMENTANO, L. Effect of water addition on selective consumption (sorting) of dry diets by dairy cattle. Journal of Dairy Science, v.79, Supp. 1., p. 62-63, 2002.

MAGALHÃES, A.L.R.; CAMPOS, J.M.S; VALADARES FILHO, S.C.; ASSIS, A.J.; NETO, J..M.; ZAMPERLIN, B. Cana-de-açúcar em substituição à silagem de milho em dietas completas para vacas em lactação. I. Produção e composição de leite In: REUNIÃO ANUAL DA SOCIEDADE BRASILEIRA DE ZOOTECNIA, 37; Viçosa, 2000. Anais. Viçosa:SBZ, 2000.

MENDONÇA, S.S; CAMPOS, J.M.S.; VALADARES FILHO, S.C.; VALADARES, R.F.D.; LANA, R.P.; SOARES, C.A.; PINA, D.S.; MACHADO, J.C. Cana-deaçúcar como volumoso único para vacas de leite. 1. Produção e composição do leite. In: REUNIÃO ANUAL DA SOCIEDADE BRASILEIRA DE ZOOTECNIA, 38; Piracicaba, 2001. Anais. Viçosa:SBZ, 2001. p.1212-1214.

MENDONÇA, S.S; CAMPOS, J.M.S.; VALADARES FILHO, S.C.; VALADARES, R.F.D.; LANA, R.P.; SOARES, C.A.; PINA, D.S.; MACHADO, J.C. Cana-deaçúcar como volumoso único para vacas de leite. III. Consumo e digestibilidade aparente dos nutrientes (compact disc). In: REUNIÃO ANUAL DA SOCIEDADE BRASILEIRA DE ZOOTECNIA, 39; Recife, 2002. Anais. Viçosa:SBZ, 2002.

MENDONÇA, S.S; CAMPOS, J.M.S.; VALADARES FILHO, S.C.; VALADARES, R.F.D.; LANA, R.P.; SOARES, C.A.; PINA, D.S.; MACHADO, J.C. Cana-deaçúcar como volumoso único para vacas de leite. IV. Comportamento ingestivo(compact disc). In: REUNIÃO ANUAL DA SOCIEDADE BRASILEIRA DE ZOOTECNIA, 39; Recife, 2002. Anais. Viçosa:SBZ, 2002. 
MERTENS, D.R. Creating a system for meeting the fiber requirements of dairy cows. Journal of Dairy Science, v.80, p. 1463-1481, 1997.

MERTENS, D.R. Comparing forage sources in dairy rations containing similar neutral detergent fiber concentration. Research Summaries, US Dairy Forage Research Center, 1995. http://www.dfrc.ars.usda.gov/RS95 pdfs/fu1.pdf (20 Ago. 2002).

MOONEY, C.S.; ALLEN, M.S. Physical effectiveness of the neutral detergent fiber of whole cottonseed relative to that of alfalfa silage at two lengths of cut. Journal of Dairy Science, v.80, p.2052-2061, 1997.

MOWREY, A; ELLERSIECK, M.R.; SPAIN, J.N. Effect of fibrous by-products on production and ruminal fermentation in lactating dairy cows. Journal of Dairy Science, v.82, p.2709-2715, 1999

NASCIMENTO FILHO, V.F. Técnicas analíticas nucleares de fluorescência de raios $X$ por dispersão de energia (ED-XRF) e por reflexão total (TXRF). Piracicaba:CENA, 1999, 31p.

NATIONAL RESEARCH COUNCIL. Nutrient requirements of domestic animals. Nutrient requirements of dairy cattle, 6 . ed. revisada Washington: National Academy of Science, 1989. 157p.

NATIONAL RESEARCH COUNCIL. Nutrient requirements of domestic animals. Nutrient requirements of dairy cattle, 7. ed. revisada Washington: National Academy of Science, 2001. 157p. 
NUSSIO, L.G.; MANZANO, R.P.; AGUIAR, R.N.S.; CRESTANA, R.F.; BALSALOBRE, M.A. Silagem do excedente de produção das pastagens para suplementação na seca. In: SIMPÓSIO SOBRE MANEJO E NUTRIÇÃO DE GADO DE CORTE, Goiânia, 2000. Anais. Goiânia: CBNA, 2000. p.121-138.

OBA, M.; ALLEN, M.S. Evaluation of the importance of the digestibility of neutral detergent fiber from forage: Effects on dry matter intake and milk yield of dairy cows. Journal of Dairy Science, v.82, p.589-596, 1999.

OBA, M.; ALLEN, M.S. Effects of brown midrib mutation in corn silage on productivity of dairy cows fed two concentration of dietary neutral detergent fiber: 2. Chewing activities. Journal of Dairy Science, v.83, p.1342-1349, 2000.

PALMQUIST, D.L. Digestibility of lint fiber and whole oilseeds by ruminal microorganisms. Animal Feed Science and Technology, v. 56, p.231-242, 1995.

PEREIRA, M.N.; GARETT, E.F.; OETZEL, G.R.; ARMENTANO, L. Partial replacement of forage with nonforage fiber sources in lactating cow diets. I. Performance and health. Journal of Dairy Science, v.82, p.2716-2730, 1999.

PEREIRA, E.S.; QUEIROZ, A.C.; VALADARES FILHO, S.C.; PAULINO, M.F.; MIRANDA, L.F.; CABRAL, L.S.; ARRUDA, A.M.V.; FERNANDES, A.M.; CAMPELO, I. Repleção ruminal da fibra em detergente neutro da cana-deaçúcar e cama de frango (compact disc). In REUNIÃO ANUAL DA SOCIEDADE BRASILEIRA DE ZOOTECNIA, 38., Viçosa, 2000. Anais. Viçosa:SBZ, 2000. 
POORE, M.H.; MOORE, J.A.; SWINGLE, R.S.; ECK, T.P.; BROWN, W.H. Wheat straw or alfalfa hay with $30 \%$ neutral detergent fiber for lactating holstein cows. Journal of Dairy Science, v.74 p.3152-3159, 1991.

POORE, M.H.; MOORE, J.A.; SWINGLE, R.S.; ECK, T.P.; BROWN, W.H. Responses of lactating holstein cows to diets varying in fiber source and ruminal starch degradability. Journal of Dairy Science, v.76 p.2235-2243, 1993.

RIBEIRO, E.S.; QUEIROZ, A.C.; VALADARES FILHO, S.C.; PAULINO, M.F.; MIRANDA; L.F.; CABRAL, L.S.; ARRUDA, A.M.V.; FERNANDES, A.M.; CAMPELLO, I. Repleção ruminal da fibra em detergente neutro da cana-deaçúcar e cama de frango. In: REUNIÃO ANUAL DA SOCIEDADE BRASILEIRA DE ZOOTECNIA, 38; Viçosa, 2000. Anais. Viçosa:SBZ, 2000.

RINNE, M.; HUHTANEN, P.; JAAKKOLA, S. Digestive processes of dairy cows fed silages harvested at four stages of grass maturity. Journal of Animal Science, v. 80, p.1986-1998, 2002.

ROBINSON, P.H.; McQUEEN. R.E. Influence of level of concentrate allocation and fermentabitity of forage fiber on chewing behavior and production of dairy cows. Journal of Dairy Science, v.80, p.681-691, 1997.

RUSSELL, J.B. The importance of $\mathrm{pH}$ in the regulation of ruminal acetate to propionate ratio and methane production in vitro. Research Summaries, US Dairy Forage Research Center, 1995. http://www.dfrc.ars.usda.gov/RS98 pdfs/wwwpp66-67.pdf (20 Ago. 2002). 
SANTINI, F.J; HARDEE, A.R.; JORGENSEN, N.A.; FINNER, M.F. Proposed use of adjusted intake based on forage particle length for calculation of roughage indexes. Journal of Dairy Science, v.66, p.811-820, 1983.

SARWAR, M., FIRKINS, J.L.; EASTRIDGE, M.L. Effects of varying forage and concentrate carbohydrates on nutrient digestibilities and milk production by dairy cows. Journal of Dairy Science, v.74, p.1006-1017, Jul. 1992.

SAUVANT, D.; MERTENS, D.R. Dietary characteristics affecting ruminal acidosis. Research Summaries, US Dairy Forage Research Center, 1995. http://www.dfrc.ars.usda.gov/RS98 pdfs/wwwpp73-74.pdf (20 Ago. 2002).

SAS INSTITUTE. SAS: users guide; statistics. version 6.11. Cary, 1996.

SCHNEIDER, B.H.; FLATT, W.P. The evaluation of feeds through digestibility experiments. Athens: The University of Georgia Press, 1975. $423 p$.

SCHWAB, E.C.; SHAVER, R.D.; SHINNERS, K.J.; LAUER, J.G.; COORS, J.G. Processing and chop length effects in brown-midrib corn silage on intake, digestion, and milk production by dairy cows. Journal of Dairy Science, v.85, p.613-623, 2002.

SHAVER, R.D.; NYTES, A.J.; SATTER, L.D.; JORGENSEN, N.A. Influence of feed intake, forage physical form, and forage fiber content on particle size of masticated forage, ruminal digesta, and feces of dairy cows. Journal of Dairy Science, v.71, p.1566-1572, 1988. 
SLATER, A.L.; EASTRIDGE, M.L.; FIRKINS, J.L.; BIDINGER, L.J. Effects of starch source and level of forage neutral detergent fiber on performance by dairy cows. Journal of Dairy Science, v.83, p.313-321, 2000.

SOITA, H.W.; CHRISTENSEN, D.A.; McKINNON, J.J. Influence of particle size on the effectiveness of the fiber in barley silage. Journal of Dairy Science, v.83, p.2295-2300, 2000.

SUDWEEKS, E.M.; ELY, L.O.; SISK, L.R.. Effect of intake on chewing activity of steers. Journal of Dairy Science, v.63, p.152-154, 1980.

SUDWEEKS, E.M.; ELY, L.O., MERTENS, D.R.; SISK, L.R. Assessing minimum amounts and form of roughages in ruminant diets: roughage value index system. Journal of Animal Science, v.53, p.1406-1411, May 1981.

SUKHIJA, P.S.; PALMQUIST, D.L. Rapid method for determination of total fatty acid content and composition of feedstuffs and feces. Journal of Agricultural Food Chemists, v.36, p.1202-1206, 1988.

SULLIVAN, J.L.; HUBER, J.T.; HARPER, J.M. Performance of dairy cows fed short staple, pima, and cracked pima cottonseed and feed characteristics. Journal of Dairy Science, v.76, p.3555-3561, 1993.

SUTTON, J.D. Altering milk composition by feeding. Journal of Dairy Science, v.72, p.2801-2814, 1989.

SWAIN, S.M., ARMENTANO, L.E. Quantitative evaluation of fiber from nonforage sources used to replace alfalfa silage. Journal of Dairy Science, v.77, p.2318-2331, 1994. 
UDEN, P.; COLUCCI, P.E.; VAN SOEST, P.J. Investigation of chromium, cerium and cobalt as markers in digesta rate of passage studies. Journal of the Science of Food and Agriculture. v. 31, p. 625-632, 1980.

UNDERSANDER, D., MERTENS, D.R., THIEX, N. Recommends forage analyses procedures. Omaha. National Forage Testing Association, $1993.154 p$

VAN SOEST, P. Nutritional ecology of the ruminant. 2 ed.. Ithaca: Cornell University Press, 1994. 476p.

VAN SOEST, P.; ROBERTSON, J.B.; LEWIS, B.A. Methods for dietay fiber, neutral detergent fiber, and nonstarch polysaccharides in relation to animal nutrition. Journal of Dairy Science, v. 74. 3583-3597, 1991.

WAGNER, K.M.; FIRKINS, J.L.; EASTRIDGE, M.L.; HULL, B.L. Replacement of corn silage with wheat middlings and calcium chloride or sodium bicarbonate for lactating dairy cows. Journal of Dairy Science, v. 76. 564574, 1993.

WANG, Z.; EASTRIDGE, M.L.; QIU, Z. Performance of cows during early lactation as affected by level of forage neutral detergent fiber and yeast culture supplementation. Journal of Dairy Science, v.82, Suppl 1., p. 70 (abst.), 1999.

WEIDNER, S.J.; GRANT, R.J. Altered ruminal mat consistency by high percentages of soybean hulls fed to lactating dairy cows. Journal of Dairy Science, v.77, p.522-532, 1994a.

WELCH, J.G. Rumination, particle size and passage from the rumen. Journal of Animal Science, v.54, p.885-894, 1982. 
WELCH, J.G.; SMITH, A.M. Physical stimulation of rumination activity. Journal of Animal Science, v.33, p.1118-1123, 1971.

WOODFORD, S.T.; MURPHY, M.R. Effect of forage physical form on chewing activity, dry matter intake, and rumen function of dairy cows in early lactation Journal of Dairy Science, v.71, p.674-686, 1988.

YOUNKER, R.S.; WINLAND, S.D.; FIRKINS, J.L.; HULL, B.L. Effects of repalcing forage fiber or nonfiber carbohydrates with dried brewers grains. Journal of Dairy Science, v.81, p.2645-2656, 1998.

ZHU, J.S.; STOKES, S.R.; MURPHY, M.R. Substitution of neutral detergent fiber from forage with neutral detergent fiber from by-products in the diets of lactating. Journal of Dairy Science, v.80, p.2901-2906, 1997. 